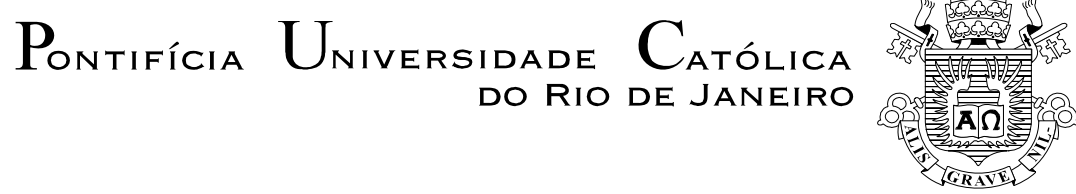

Andre Martins Bogossian

Aspectos Conceituais e Descritivos da Regra de Reconhecimento do Direito Brasileiro

Dissertação de Mestrado

Dissertação apresentada ao Programa de Pósgraduação em Direito da PUC-Rio como requisito parcial para obtenção do título de Mestre em Direito.

Orientador: Prof. Noel Struchiner 
Andre Martins Bogossian

\section{Aspectos Conceituais e Descritivos da Regra de Reconhecimento do Direito Brasileiro}

Dissertação apresentada como requisito parcial para obtenção do título de Mestre pelo Programa de Pós-Graduação em Direito do Departamento de Direito da PUC-Rio. Aprovada pela Comissão Examinadora abaixo assinada.

Prof. Noel Struchiner

Orientador

Departamento de Direito - PUC-Rio

Prof. Fábio Carvalho Leite Departamento de Direito - PUC-Rio

Prof. Fábio Perin Shecaira UFRJ

Profa. Mônica Herz Vice-Decana de Pós-Graduação do Centro de

Ciências Sociais - PUC-Rio

Rio de Janeiro, 17 de abril de 2015. 
Todos os direitos reservados. É proibida a reprodução total ou parcial do trabalho sem autorização da universidade, do autor e do orientador.

\section{Andre Martins Bogossian}

Graduou-se em Direito pela Faculdade Nacional de Direito da Universidade Federal do Rio de Janeiro (UFRJ) em 2010. Ingressou no Mestrado em Direito na Pontifícia Universidade Católica em 2013. Atua principalmente em direito constitucional, teoria do Estado e teoria do direito.

Ficha Catalográfica

Bogossian, Andre Martins.

Aspectos conceituais e descritivos da regra de reconhecimento do direito brasileiro / Andre Martins Bogossian; orientador: Noel Struchiner. - Rio de Janeiro: PUC-Rio, Departamento de Direito, 2015.

$163 \mathrm{f} .: 29,7 \mathrm{~cm}$

Dissertação (mestrado) - Pontifícia Universidade Católica do Rio de Janeiro. Departamento de Direito.

Inclui bibliografia

1. Direito - Teses. 2. Regra de reconhecimento. 3. Direito brasileiro. 4. H.LA. Hart. 5. Teoria do Direito. 6. Direito Constitucional. I. Struchiner, Noel. II. Pontifícia Universidade Católica do Rio de Janeiro. Departamento de Direito. III. Título. 


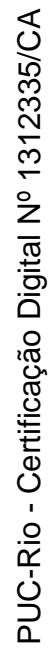

A Adélia e Levão, in memoriam 


\section{Agradecimentos}

A Deus, por tudo.

A Augusto e Ana, pelo suporte incondicional em todas as minhas escolhas.

Ao orientador e amigo Noel Struchiner, por ter acolhido um constitucionalista confuso que se aventurava pretensiosamente na teoria analítica do direito. Obrigado por mostrar o caminho do rigor, da clareza e da honestidade intelectual. E, claro, pelas caronas e marcações nos muitos livros generosamente cedidos: quadrados, círculos, quadrados com círculos e todo o resto de uma simbologia que foi um verdadeiro caminho das pedras.

Aos amigos Pedro, Danilo e Thiago, pelas críticas às ideias deste trabalho.

À PUC-Rio e ao CNPq pelo auxílio.

À Brown University, nas figuras ímpares dos professores David Estlund e Steven G. Calabresi, por três meses extremamente enriquecedores intelectualmente.

Ao Anderson e à Carmem, peças fundamentais neste Programa de Pós-Graduação.

Aos irmãos beneditinos, pela lealdade de uma amizade de duas décadas.

Ao Kim e ao Tom, pelos debates metafísicos a respeito da ontologia da regra de reconhecimento.

À Alana, por ter comprado o pacote e pacientemente mantê-lo. 


\section{Resumo}

Bogossian, Andre Martins; Struchiner, Noel. Aspectos conceituais e descritivos da regra de reconhecimento do direito brasileiro. Rio de Janeiro, 2015. 163p. Dissertação de Mestrado - Departamento de Direito, Pontifícia Universidade Católica do Rio de Janeiro.

O positivismo jurídico de H.L.A. Hart oferece respostas para a pergunta fundamental a respeito do conceito de direito com uma formulação bastante sofisticada, envolvendo a união de regras primárias e secundárias. Dentre os aspectos de maior relevância do modelo desenvolvido, ocupa posição central a figura da regra (última) de reconhecimento, regra secundária pensada como solução para o problema da incerteza, que advém da dificuldade de identificar quais regras pertencem ao ordenamento jurídico da comunidade e qual o âmbito de sua aplicação. A proposta do presente estudo é partir do marco teórico desenvolvido por Hart em 'O Conceito de Direito', trabalhando-o na interface entre a teoria do direito e o direito constitucional e procurando aplicar a teoria hartiana ao fenômeno jurídico brasileiro. Assim, os dois primeiros capítulos tratarão de questões conceituais a respeito do instituto tratado, com a identificação de algumas dificuldades na versão canônica e culminando com a proposta de uma nova compreensão do instituto, que considere o povo no grupo reconhecedor relevante. Por fim, no quarto capítulo, tenta-se descrever a regra última de reconhecimento do direito brasileiro, considerando as atuais práticas relevantes da comunidade político-jurídica brasileira de identificação do direito válido.

\section{Palavras-chave}

Regra de reconhecimento; H.L.A Hart; Grupo reconhecedor; Constituição; Teoria do direito; Direito Brasileiro. 


\section{Abstract}

Bogossian, Andre Martins; Struchiner, Noel (advisor). Conceptual and descriptive aspects of the rule of recognition in Brazil. Rio de Janeiro, 2015. 163p. MSc. Dissertation - Departamento de Direito, Pontifícia Universidade Católica do Rio de Janeiro.

H.L.A Hart' legal positivism offers answers to the fundamental question about the concept of law with a very sophisticated formulation, involving the union of primary and secondary rules. Among the most relevant aspects of the developed model, at its core rests the (ultimate) rule of recognition, a secondary rule designed as a solution to the problem of uncertainty, stemming from the difficulty of identifying which rules belong to the community's legal system and their scope of application. The purpose of this study is, from the theoretical framework developed by Hart in 'The Concept of Law', to work in the interface between the legal theory and the constitutional law, and to apply the hartian theory to the Brazilian legal phenomenon. Thus, the first two chapters will address conceptual issues regarding the rule of recognition institute, identifying some problems in its canonical reading, and will culminate with the proposal of a new understanding of the institute, one that places the people in the relevant recognitional group. Finally, at the fourth chapter, there will be an attempt to describe the ultimate rule of recognition of Brazilian law, considering the current relevant practices of the Brazilian legal and politic community in identifying the law.

\section{Keywords}

Rule of recognition; H.L.A Hart; recognitial group; Constitution; Legal Theory; Brazilian Law. 


\section{Sumário}

Sumário 8

Lista de Abreviaturas 10

1. Introdução (o direito como união de regras primárias e secundárias) 12

2. Alguns aspectos conceituais 19

2.1. Regra de reconhecimento, Constituição e ordenamento jurídico 23

2.2. Pluralidade ou unidade da regra de reconhecimento? 28

2.3. A natureza da regra de reconhecimento 33

2.3.1. Regra Costumeira 37

2.3.2. A Teoria das Regras Sociais como Práticas 39

2.3.3. O(s) convencionalismo(s) 41

2.4. Reconhecer é aceitar 47

2.5. Quando ocorre o reconhecimento? 55

2.6. Alteração da regra de reconhecimento 57

3. Alguns problemas persistentes 62

3.1. As regras secundárias e uma (im)possível distinção 62

3.1.1. O problema da circularidade 68

3.2. A normatividade da regra de reconhecimento 75

3.2.1. Regras que conferem poderes, regras que impõem deveres e regras constitutivas $\quad 77$

3.2.2. O papel da regra de reconhecimento na normatividade do direito 80

3.2.3. O problema da normatividade 84

3.3. Quem é o grupo reconhecedor relevante? 88

3.3.1. Ignorantes, ovelhas e a aceitação do direito 95

3.4. Por uma nova compreensão do grupo reconhecedor relevante 102 
4. A regra de reconhecimento do direito brasileiro 113

4.1. A Constituição Federal de 1988 como ponto de partida 115

4.2. As cláusulas pétreas e o critério supremo do direito brasileiro 124

4.3. Regras de adjudicação e a supremacia judicial "à brasileira" 130

4.4. Regras de alteração: reformas e mutações constitucionais 137

4.5. A incorporação de fatores morais e os princípios na Constituição brasileira

5. Conclusão

6. Referências Bibliográficas 154

Legislação 162

Decisões Judiciais 163

Sítios Virtuais 


\section{Lista de Abreviaturas}

ADC - Ação Declaratória de Constitucionalidade

ADI - Ação Direta de Inconstitucionalidade

ADPF - Arguição de Descumprimento de Preceito Fundamental

AI - Agravo de Instrumento

CF/88 - Constituição da República Federativa do Brasil

EC - Emenda Constitucional

PEC - Proposta de Emenda Constitucional

STF - Supremo Tribunal Federal 
Who Are the Best Keepers of the People's Liberties? The People themselves. The sacred trust can be nowhere so safe as in the hands most interested in preserving it. James Madison National Gazette, 22 de dezembro de 1792 


\section{1 Introdução (o direito como união de regras primárias e secundárias)}

A teoria desenvolvida por H.L.A. Hart na sua obra O Conceito de Direito (inicialmente publicado em 1961, com um pós-escrito lançado post mortem em 1994) é, sem dúvidas, um marco para o positivismo jurídico. Apesar de injustamente não receber o devido crédito no Brasil, Hart é comumente celebrado como um dos mais influentes pensadores e detentor de uma das mais sofisticadas teorias nesse ramo do saber jurídico, tendo sido o responsável pelo renascimento da filosofia e teoria do direito na Inglaterra no meio do século XX (Hacker, 1977, p.v). Hart “carregou a tocha” da grande tradição positivista (Gardner, 2013, p.92) fazendo a transição das teorias clássicas de Bentham e Austin para o positivismo contemporâneo. Não é à toa que o maior e mais famoso dos críticos ao positivismo jurídico, Ronald Dworkin (2002, p. 27), explicitamente dirigiu seus ataques à obra de Hart, reconhecendo sua importância e complexidade:

Desejo examinar a solidez do positivismo jurídico, especialmente na forma poderosa que lhe foi dada pelo Professor H. L. A. Hart. Resolvi concentrar-me na sua posição não apenas devido a sua clareza e elegância, mas porque neste caso, como em quase todas as outras áreas da filosofia do direito, o pensamento que visa construir deve começar com um exame das concepções de Hart.

Dentre as propostas de Hart, a construção teórica da regra de reconhecimento é, sem dúvida, uma das mais importantes e duradouras, sendo uma de suas maiores contribuições à teoria do direito (Kramer, 2004, p. 104), e talvez nenhuma outra ideia seja tão associada com o positivismo hartiano (Marmor, 2011, p. 50).

Aqui também o trabalho será iniciado com um exame conceitual das propostas de Hart, não para destruí-las, mas, ao contrário, para (a) oferecer uma leitura democrática a respeito da comunidade reconhecedora, o grupo responsável 
pela prática social identificada com a regra secundária de reconhecimento, e (b) testar sua aplicabilidade ao ordenamento jurídico brasileiro ${ }^{1}$. Uma ressalva antes de prosseguir: tomar Hart como base para uma construção só tem sentido, obviamente, para quem considera - como é o caso - que sua obra segue constituindo o melhor ponto de partida disponível na atualidade para a Teoria do Direito. Mas tomar Hart como ponto de partida deve ser um exercício consciente também da "necessidade de eliminar de sua teoria certas inconsistências ${ }^{2}$, de melhor esboçar certos desenvolvimentos e de retificar algumas teses”. Não se pretende, pois, proceder a uma fiel exposição de Hart, mas "reconstruir o aporte hartiano da forma que resulte teoricamente mais frutífera” (Ruiz Manero, 1990, p. 12). Assim, se não é o objetivo deste trabalho uma crítica destrutiva do positivismo em versão hartiana, também não se pretende aqui elaborar uma mera exegese do que de fato disse ou quis dizer Hart, ou até mesmo utilizá-lo como argumento de autoridade em defesa das posições apresentadas; o estudo ora desenvolvido propõe-se a, partindo das sólidas fundações do positivismo hartiano $^{3}$, ir além e abordar as questões postas sob um prisma transdisciplinar.

Pretende-se: (a) avançar em uma proposta que seja adequada à estrutura geral do positivismo jurídico, mas que também possa estar aberta ao diálogo com a filosofia política e a teoria constitucional; (b) oferecer uma perspectiva ainda não explorada para analisar o direito brasileiro, trabalhando em uma janela que se abre ao diálogo entre a Teoria do Direito e o Direito Constitucional, numa tentativa de enxergar certos fenômenos jurídicos a partir de ambas as lentes ${ }^{4}$.

${ }^{1}$ Como nota Galligan (2007, p.18), conceitos como os avançados na Teoria do Direito possuem, por um lado, uma natureza de hipóteses a respeito do mundo social e, deste modo, podem ser testados diante dos fatos.

${ }^{2}$ Até mesmo pelo simples fato, admitido por Hart em entrevista, de que seria ele um escritor 'algo descuidado', que formulou com frequência seus pontos de vista "de um modo inadequadamente ambíguo ou demasiadamente impreciso”, e cuja exposição de alguns problemas parece "não somente confusa, senão incompleta ou inconsistente” (Páramo Arguelhes, 1988, p.343).

${ }^{3}$ Como indica Peter Hacker (1977, p. 1), o trabalho de Hart deve ser visto mais pelo seu pioneirismo do que como um estudo conclusivo, ainda mais considerando as reconhecidas fragilidades (que obviamente não minam o produto final) de sua obra.

${ }^{4}$ Serão mostradas questões de vital importância tanto para o direito constitucional quanto para a teoria do direito e que podem ser vistas sob ambos os ângulos. Tome-se como exemplo a caracterização na teoria do direito da comunidade responsável pela prática de reconhecimento e o debate, no direito constitucional, a respeito de quem deve ter última voz sobre a interpretação constitucional (se é que alguém precisa ter). Ou o reconhecimento da constitucionalidade ou não de determinada norma, que para a teoria do direito pode representar uma das facetas da própria prática de reconhecimento. Ou, como notado por Gardner, o interminável debate norte-americano 
Assim, espera-se contribuir para o afastamento da percepção ironicamente notada por Schauer (1993, pp. 797-798) de que muitos dos mais relevantes assuntos da teoria analítica do direito seriam apenas digressões irrelevantes de um bando de ingleses mortos; ao contrário, estão diretamente conectadas a algumas das mais importantes questões de teoria constitucional.

O estudo trabalhará com três hipóteses. As duas primeiras, A e B, independentes entre si, servirão de premissas para que se possa extrair, de modo não dedutivo, C, a terceira hipótese, como melhor forma de explicação - ou melhor, aplicação - de A em B:

a) Partindo-se de problemas conceituais encontrados na leitura tradicional da obra de Hart, será apresentada uma proposta de concepção da regra de reconhecimento em que o grupo reconhecedor relevante contenha não somente os juízes ou as autoridades (os officials), mas também a sociedade civil. A verificação dessa hipótese ocorrerá com a apresentação de argumentos que provem sua compatibilidade com a teoria geral juspositivista;

b) Partindo-se da premissa de que a teoria de Hart é geral e descritiva, então deve ser possível aplicá-la ao direito brasileiro. A verificação da hipótese ocorrerá com a tarefa de apresentar descritivamente seus contornos;

c) Aplicando-se A) em B), será feito o mapeamento da regra de reconhecimento do direito brasileiro a partir da releitura proposta do instituto.

Quanto a A, serão apresentados problemas de duas ordens identificados na concepção tradicionalmente defendida pela doutrina hartiana e apresentados argumentos favoráveis à hipótese proposta que identifica também na sociedade civil o grupo reconhecedor relevante; Quanto a B e C, as questões que nortearão o estudo na tentativa de estabelecer os contornos da regra de reconhecimento no Brasil lidarão com temas, dentre os quais, a caracterização de um positivismo inclusivo, considerando a introdução de princípios carregados de valores morais ;

a respeito dos métodos de interpretação constitucional, entre os que acham que a Constituição se acha somente no documento que foi escrito em 1787 pelos founding fathers e suas posteriores emendas e os que dizem que a constituição é um “documento vivo" que não deveria ser congelado no momento de sua adoção (Gardner, 2011, p.198), que configura a questão da temporalidade da prática de reconhecimento.

${ }^{5}$ Note-se que a possibilidade do reconhecimento da incorporação no ordenamento jurídico brasileiro de aspectos morais por meio dos princípios em nada afasta a fidelidade da análise ao positivismo. O que há de mais característico no positivismo é a afirmação de que o direito não é derivado necessariamente de princípios morais, mas simplesmente é "posto" por 
ao reconhecimento das cláusulas pétreas como indicadores da existência de um critério supremo; à problematização da competência do Supremo Tribunal Federal como guardião da Constituição e sua possível implicação em uma talvez inafastável supremacia judicial (superficial) no Brasil; à problematização das mutações constitucionais; e à identificação das regras secundárias de alteração e adjudicação do direito brasileiro. Com isso, é possível perceber que serão abordadas as questões fundamentais do direito constitucional, ao tratar da limitação e organização do poder estatal, além da garantia de direitos fundamentais. O estudo passará por esses temas focando - nunca é demais frisar seu papel no mapeamento da regra de reconhecimento para o direito brasileiro. Não se pretende discorrer monograficamente sobre os temas acima indicados, mas tão somente serão abordados na medida em que possam contribuir para o mapeamento proposto.

Deste modo, o trabalho será desenvolvido sob a seguinte estrutura: a primeira parte tratará de algumas questões conceituais a respeito do instituto tratado, em um panorama de como Hart e seus seguidores desenvolveram o conceito ao longo dos anos. A segunda parte do trabalho continuará a problematizar temas conceituais e apresentará duas dificuldades que a leitura tradicional - que identifica apenas nos officials (também aqui denominados agentes públicos ou autoridades públicas) o grupo reconhecedor relevante parece não conseguir solucionar de modo satisfatório: o problema da circularidade e o da normatividade. Afirma-se que para ambos os problemas a melhor solução envolve considerar o povo no grupo reconhecedor relevante, e que tal "releitura" da regra de reconhecimento é viável conceitualmente, além de deter maior poder explicativo da realidade jurídica.

Como anteriormente notado, a escolha do tema se deve, por um lado, à oportunidade de trabalhar em uma zona de interseção da Teoria do Direito com o Direito Constitucional. Some-se a isso o ineditismo na abordagem, a partir da matriz hartiana, do direito brasileiro. Não se nega a inspiração na obra coletiva

seres humanos e instituições humanas; ou seja, a suposta incorporação de valores morais nos critérios de validade do direito é contingente e não necessária, fruto de uma decisão humana para um determinado sistema jurídico (Schauer, 1998, p. 69). Mas isso não significa que para o positivista o direito seja imoral ou amoral; como frisa Schauer (1993, p. 801), o direito pode muito bem ser moralmente bom- mas não é necessariamente moral, a moralidade não é uma condição de legalidade em todos os sistemas jurídicos possíveis. 
editada por Matthew D. Adler e Kenneth Himma, "The Rule of Recognition and the U.S Constitution” (2009), além de outros trabalhos individuais, como os de Greenwalt (1987, inserido na obra coletiva citada), Schauer (1995), Adler (2006), Carey (2009), entre outros que, de modo mais ou menos direto, se incumbiram da árdua tarefa de procurar identificar sob diversas perspectivas a prática social complexa que dá fundamento de validade ao ordenamento jurídico norteamericano.

Assim, a terceira parte do presente trabalho irá tentar oferecer uma descrição da regra de reconhecimento do direito brasileiro, uma verdadeira tentativa de mapeamento do terreno constitucional (Schauer 1993, p. 804) ${ }^{6}$. Opera-se com a já aludida hipótese da possibilidade de se falar em uma regra de reconhecimento para o direito brasileiro fazendo-se jus à pretensão de Hart em oferecer um arcabouço teórico capaz de pensar o direito de modo geral e descritivo (Hart, [1961] 2009, p.309). A tarefa será, portanto, estabelecer os contornos que deve possuir tal regra secundária à luz da releitura proposta na segunda parte.

Entretanto, antes de iniciar a investigação dos aspetos conceituas da regra de reconhecimento, é necessária uma breve introdução que, em linhas gerais, permita a compreensão do pano de fundo teórico no qual se insere tal regra; ou seja, uma breve exposição de como Hart chega à concepção da regra de reconhecimento.

Para tanto, é necessário buscar na sua mais famosa obra, O Conceito de Direito ([1961] 2009), as fundações da teoria hartiana do direito. Hart parte de uma crítica à teoria imperativa de Austin (que trata o direito como um conjunto formado apenas por comandos - regras primárias criadoras de deveres e obrigações), demonstrando sua incapacidade para explicar com precisão o fenômeno jurídico ([1961] 2009, pp. 23-102), para então propor a compreensão do “direito como união de normas primárias e secundárias” ([1961] 2009, p. 103), capaz de responder à incapacidade, por ele identificada na teoria austiniana, de explicar certos fenômenos com precisão.

6 "Mapear significa identificar e descrever suas características principais (...) a explicação de fenômenos sociais nao é um processo mecânico conduzido por robôs; ela depende de o observador ter objetivos específicos para então classificar e entender o mundo social de acordo com eles” (Galligan, 2007, p.34). 
Para destacar a importância das regras secundárias Hart recorre a um experimento de pensamento ${ }^{7}$ envolvendo uma hipotética comunidade "primitiva", simples, que se organiza somente em torno de regras primárias e posteriormente evolui para uma estrutura mais complexa, e na qual identifica três problemas. Ao primeiro chama de "problema da incerteza" ([1961] 2009, p. 119), que advém da dificuldade de identificar quais as regras que pertencem à comunidade ou qual o âmbito de sua aplicação; ao segundo, relativo à rigidez de um conjunto de regras somente primárias, Hart chama “problema do caráter estático” das regras ([1961] 2009, p. 120), eis que inexistiriam formas institucionais de criar novas regras e de fazer outras deixarem de existir, o que dificultaria a adaptação do conjunto de regras às novas circunstâncias. Finalmente, o terceiro, relativo ao caráter de eficácia, é denominado “problema da ineficiência” ([1961] 2009, p. 121): o protodireito em questão não apresentaria formas adequadas de lidar com conflitos de interesses baseados na interpretação e aplicação das próprias regras primárias, não há regras institucionalizando a solução de conflitos.

Para esses três problemas, Hart apresenta soluções na forma de regras secundárias, que, apesar de também fazerem parte do gênero regras, formam uma espécie diferente, pois versam sobre as regras primárias, especificando como estas podem ser determinadas, introduzidas, eliminadas e alteradas, bem como se deve determinar a sua violação. A introdução das três regras secundárias teria o efeito de operar a transição do sistema pré-jurídico para o mundo do direito: “certamente, combinados, os três recursos bastam para converter o regime de

${ }^{7}$ Como muitas formulações tradicionais da teoria política que procuram dar conta da transição de um hipotético estado de natureza para o estado civil, tal experimento mental é melhor compreendido como uma representação do que as sociedades perderiam hoje abandonando as práticas que caracterizam um sistema jurídico desenvolvido do que como uma representação do que faltava aos sistemas jurídicos de comunidades históricas passadas (Waldron, 1999, p. 173; MacCormick, 2008, p.136), não devendo, portanto, ser entendido como a generalização de um estudo antropológico, mas sim uma análise conceitual (Hacker, 1977, p.12) - temática e esquemática, não histórica (MacCormick, 2008, p.135) - uma pauta explicativa para compreender de uma forma mais plausível as funções das regras nos ordenamentos jurídicos desenvolvidos. Ele não se importa - e não tem razão para tanto - se é deste modo que os sistemas jurídicos surgem ou se ao menos um sistema assim se desenvolveu (Gardner, 2013, p. 82). Como o próprio Hart afirma, poucas sociedades que existiram careceram completamente de ordens legislativas e jurisdicionais e de sanções centralmente organizadas, pois em geral as sociedades pressupõem a existência de certos mecanismos de controle social (Páramo Argüelles, 1984, p.217). 
normas primárias em algo que é indiscutivelmente um sistema jurídico” ([1961] 2009, pp. 121-122) ${ }^{8}$.

Assim, Hart introduz como solução para os citados problemas, respectivamente, as figuras das regras (normas) de reconhecimento, alteração (modificação) e adjudicação (julgamento).

A regra de reconhecimento "especifica as características que se estiverem presentes numa determinada norma serão consideradas como indicação conclusiva de que se trata de uma norma do grupo" ([1961] 2009, p.122). Por sua vez, a regra de alteração indica os sujeitos que podem e o modo de introduzir novas normas no ordenamento e revogar ou alterar as vigentes ([1961] 2009, p.124). Por fim, a regra de adjudicação identifica os indivíduos e procedimentos necessários para definição da violação de uma norma primária ([1961] 2009, p.125).

Assim, ganham forma as práticas institucionalizadas mais trivialmente reconhecidas com o direito, como as de produção, interpretação e aplicação desse material normativo primário, ocorrendo também a institucionalização e especialização das funções relativas a essas práticas e o reforço de certas figuras que serão recorrentes no presente estudo, como do juiz e dos officials ${ }^{9}$. É nesse cenário que as atenções agora se voltam para a peça mais importante dos ordenamentos jurídicos, a regra de reconhecimento.

${ }^{8}$ Na verdade, Hart define duas condições essenciais para se considerar um sistema jurídico desenvolvido: a união de regras primárias e secundárias e um conjunto de instituições para criar, interpretar e aplicar tais regras (Galligan, 2007, p.8). Como será visto, essas instituições são criadas e disciplinadas pelas regras secundárias, o que evidencia ainda mais a fundamentalidade de tais normas para os sistemas desenvolvidos.

${ }^{9} \mathrm{O}$ termo em língua inglesa `officials` será aqui traduzido como autoridades, autoridades públicas ou agentes públicos. 


\section{2}

\section{Alguns aspectos conceituais}

Neste capítulo serão apresentados os contornos conceituais básicos da regra de reconhecimento. No percurso, serão citadas algumas propostas de caracterização do instituto feitas por relevantes comentadores de Hart, além de passagens do próprio autor. Alguns conceitos que agora serão lançados serão posteriormente retomados e desenvolvidos na evolução deste capítulo, em cada uma de suas seções.

Hart apresenta a regra de reconhecimento como uma regra secundária que se destina a solucionar o problema da incerteza ao reconhecer quais normas fazem parte do ordenamento jurídico. Sua construção é fiel à tradição juspositivista que identifica o direito válido segundo critérios de fonte e não de mérito - ou seja, o critério de identificação a que a regra de reconhecimento se refere deverá ser um critério que não dependa necessariamente de questões de mérito das normas (Schauer 1993, pp. 799-800). É uma regra juridicamente última no sentido de que fornece uma série de critérios pelos quais, direta ou indiretamente, avalia-se a validade de todas as demais regras do sistema, não sendo ela mesma objeto de semelhante relação com nenhuma outra regra. Ela não deve ser caracterizada como juridicamente válida ou inválida - embora possa ser objeto de crítica moral, explicação histórica ou sociológica e outras formas de exame. Sua existência é manifesta no reconhecimento e no uso do mesmo conjunto de critérios de validade jurídica pelos responsáveis pela criação, aplicação e implementação do direito e à conformidade geral com o direito assim identificado (Hart, 2010, p. 404).

É a própria regra de reconhecimento que vai indicar quais são os critérios de fonte (ou de mérito, para o positivismo inclusivo) a serem utilizados para verificar (direta ou indiretamente) o pertencimento de qualquer norma ao sistema jurídico. Mais do que isso, a regra de reconhecimento imprime uma marca nas normas sob ela constituídas - nas palavras de Coleman (2001, p.356), trata-se da 
assinatura de um sistema jurídico, um traço comum pelo qual podem ser identificadas todas as normas do sistema. Galligan (2007, p.96), por sua vez, a percebe como uma metáfora para a aceitação do sistema jurídico como um todo; uma metáfora representada por um conjunto de práticas sociais a respeito do que conta como direito em uma dada sociedade.

Ela é, portanto, uma regra social: para Hart o próprio direito é um construto social (Coleman, 1991, p. 705), as regras jurídicas são regras sociais percebidas no seu ponto de vista interno (Hart, [1961] 2009, pp. 115-116), e assim também a regra de reconhecimento deve ser percebida. Segundo MacCormick (2008, p.31), Hart trata o direito como conjunto de regras sociais tanto por deverem sua origem exclusivamente a práticas sociais humanas quanto pelo fato de que governam a conduta de seres humanos em sociedades.

De modo mais específico, a regra de reconhecimento pode ser considerada “social” em dois sentidos: no primeiro, a regra de reconhecimento existe e tem o conteúdo que tem pelo fato de que membros do grupo adotam o ponto de visto interno em respeito a certos padrões de conduta e o utilizam para avaliar a validade de normas e comportamentos em seu escopo; em segundo lugar, a regra de reconhecimento seria social no sentido de que ela infirma um padrão para todos os membros do grupo, que tratam o padrão como o modo oficial que o direito deve ser determinado naquela comunidade (Shapiro, 2009, p. 239) - o “padrão público e comum” nos termos de Hart ([1961] 2009, p. 149). É nesse primeiro sentido que Hart fala em uma 'prática social complexa', que "envolve a identificação do direito pelos tribunais, autoridades públicas e indivíduos privados por meio da referência a determinados critérios” (1961] 2009, p. 142). Sua fonte, portanto, está em um enunciado factual, em uma prática social, não em pressuposições ou conceitos morais.

A regra de reconhecimento não requer ou implica uma formulação expressa de si mesma - sua existência está radicada em práticas sociais, na maneira em que o direito é identificado pelos tribunais, autoridades públicas, consultores jurídicos e a sociedade como um todo - a regra não é mencionada, ela é usada (Páramo Argüelles, 1984, p.245). Na verdade, o próprio autor de O Conceito de Direito afirma (Hart, [1961] 2009, p.131) ser raro que normas de reconhecimento sejam formuladas: 
(...) em geral, não são explicitamente declaradas mas sua existência fica demonstrada pela forma como se identificam normas específicas, seja pelos tribunais ou outras autoridades, seja por indivíduos particulares ou seus advogados .

Hart ([1961] 2009, p.130) prossegue afirmando que a regra de reconhecimento pode assumir diversas formas, incluindo a "referência a um texto autorizado; a um ato legislativo; à prática consuetudinária; a declarações gerais de pessoas específicas; ou, em casos particulares, a decisões judiciais anteriores sobre casos específicos”. Ou seja, a regra de reconhecimento pode conter desde uma indicação de que faz parte do direito tudo aquilo que o Rei (ou o Parlamento, um Supremo Tribunal ou até um velho ancião) disser, até critérios mais complexos, em sociedades cujo sistema possua várias fontes, envolvendo a abertura para a compatibilidade do ordenamento inferior a uma Constituição, de acordo com a sua interpretação pelos órgãos para tanto instituídos. Note-se que Hart ([1961] 2009, p.131) expressamente admite que tal regra (ou regras - a unidade ou pluralidade da regra de reconhecimento é questão intensamente debatida) possua uma variedade de critérios com hierarquias diferentes, desde que compatíveis entre si. Também não importa, para Hart ([1961] 2009, p.123), o motivo pelo qual a regra é aceita; crucial é considerar a regra de reconhecimento (qual seja sua forma ou conteúdo) como fonte da autoridade, isto é, a maneira correta de esclarecer dúvidas sobre a existência (e validade) das normas jurídicas. Validade, por sua vez, é normalmente mencionada em um contexto de um enunciado interno ao sistema jurídico, em que se aplica uma regra de reconhecimento a uma norma específica do sistema jurídico. "Dizer que uma norma é válida equivale a reconhecer que esta satisfaz a todos os critérios propostos pela norma de reconhecimento e é, portanto, uma norma do sistema” (Hart, [1961] 2009, p.133).

Deve-se, entretanto, evitar confundir este enunciado interno que utiliza a regra de reconhecimento com o enunciado externo que procura descrever o critério de identificação das regras do sistema baseado na regra de reconhecimento (como o usado por um observador externo). Uma coisa é a regra de reconhecimento de um sistema jurídico - enquanto critério ou conjunto hierarquicamente ordenado de critérios de validade jurídica aceitos como vinculantes pelo grupo relevante - e outra é o critério mediante o qual um observador externo identifica as regras desse mesmo sistema. A diferença entre a 
regra de reconhecimento como regra social aceita pelo grupo relevante e o critério teórico do ponto de vista externo na identificação das regras do sistema por referência à regra de reconhecimento fica clara, segundo Ruiz Manero (1990, p.138), nas diferenças às críticas dirigidas a um juiz que não usa as regras identificadas mediante a regra de reconhecimento como fundamento de suas decisões (que é acusado de descumprir a norma secundária de reconhecimento), e, por outro lado, ao advogado ou o teórico do direito que não identifica corretamente as regras do sistema (e é acusado de ignorar ou simplesmente falhar na sua tarefa, mas não de descumprir a regra $)^{10}$. O enunciado externo usado pelo observador identifica os critérios de validade utilizados pelos agentes que operam dentro do sistema, mas ele não é, em si, o próprio critério de validade.

A regra de reconhecimento possui algumas importantes funções reconhecidas pela doutrina. Em primeiro lugar, é possível falar em funções epistêmicas (identificação do direito) e validatórias (determinar que normas são válidas e quais não) (Schauer, 1998, pp. 66-67; Shapiro, 2009, p. 244), ao especificar condições e características de pertencimento das normas ao grupo da qual formam parte (Páramo Argüelles, 1984, p.214). É basicamente a esta função que Hart ([1961] 2009, p. 122) se refere ao dizer que a regra de reconhecimento soluciona o problema da incerteza. Além de reconhecer a função epistêmica, Coleman enxerga na regra uma função ontológica ou semântica, por especificar condições de existência e verdade para o sistema jurídico (Coleman, 1991, p.709; Hart [1961] 2009, p. 150). Alguns autores falam ainda em uma função sistêmica para fazer referência ao fato de que a regra confere existência e unidade ao ordenamento, permitindo sua identificação entre os demais sistemas jurídicos (MacCormick, 2008, p.138; Galligan, 2007, p.84; Shapiro, 2009, p. 244; Lamond 2013, p. 116). Nota-se também a referência a uma função normativa, que é fundada na premissa não unânime de que é papel da regra de reconhecimento conferir normatividade ao direito (Atienza e Ruiz Manero, 1998, p. 141, nota1; Galligan, 2007, p.84; Shapiro, 2009, p. 243).

\footnotetext{
10 “Em sentido contrário, entendendo que um juiz que deixa de aplicar ou aplica errado a regra de reconhecimento não desobedece, mas faz apenas um uso incorreto - como o falante da língua que comete erros de gramática não fala corretamente”(Bulygin, 1976, p.39). Tal posição deve-se à concepção de Bulygin da regra de reconhecimento como mera regra conceitual, que será posteriormente rejeitada quando for tratado o complexo tema da natureza da regra de reconhecimento.
} 
Em resumo, Páramo Argüelles (1984, pp. 276-277) a caracteriza, seguindo a Raz (1999, pp.146ss), nos seguintes termos: (i) uma regra de reconhecimento é uma regra que exige do grupo reconhecedor relevante a aplicação de regras identificadas por critérios de validade incluídos na própria regra de reconhecimento; (ii) todos os sistemas jurídicos têm ao menos uma regra de reconhecimento; (iii) nenhum sistema jurídico tem mais de uma regra de reconhecimento (última); (iv) cada regra de reconhecimento é aceita e praticada pelos identificados por sua regra de reconhecimento e todas as regras identificadas por ela; (v) não é necessário que o grupo reconhecedor relevante esteja de acordo com a regra sob um ponto de vista moral; (vi) um sistema jurídico consiste no conjunto formado por sua regra de reconhecimento e todas as normas identificadas por ela. No desenvolvimento deste capítulo, todas essas questões serão retomadas, contrastando as divergentes posições a respeito dos tópicos analisados.

\section{1}

\section{Regra de reconhecimento, Constituição e ordenamento jurídico}

Neste tópico, serão abordadas fundamentalmente questões relativas à relação da regra de reconhecimento com a Constituição e o sistema jurídico respectivo. Para tanto, retoma-se a função básica atribuída por Hart à regra de reconhecimento: a identificação do direito válido.

Para saber se determinado ato ou norma faz parte do ordenamento, pode-se recorrer a um raciocínio em cadeia, conferindo a cada etapa a validade da norma que lhe dá fundamento de acordo com os critérios determinados pela regra de reconhecimento. Deste modo, de um ato administrativo até a Constituição Federal ${ }^{11}$ é possível erigir um encadeamento de relações de validade fundadas em critérios de fonte que, na imensa maioria dos ordenamentos jurídicos contemporâneos, termina nas Constituições.

${ }^{11}$ O exemplo é semelhante aos apresentados por Hart ([1961] 2009, p.138), Schauer (1995, p.148) e Green (1999, p.35). 
Surge, entretanto, um problema: o que torna válida uma Constituição ${ }^{12}$ ? O que faz uma constituição ser constitucional? O fato de que tais perguntas não são feitas no quotidiano dos operadores do material jurídico primário não quer dizer que não sejam indagações relevantes ou que possam ser evitadas. Como indicam Atienza e Ruiz Manero (1998, p. 142), a importância destas questões fica aparente quando os operadores do direito têm que tratar da obrigatoriedade das normas contidas na fonte suprema, ou seja, lidar com a questão aparentemente básica e fundamental da aplicação das normas constitucionais. Para o Direito Constitucional - mais especificamente para a Teoria da Constituição - a questão é respondida (segundo uma tradicional maioria) adotando-se a concepção de que é o fato de a Constituição ser manifestação do Poder Constituinte Originário, dotado de soberania (popular), que a torna norma suprema (Silva, 2014, p. 183). Ainda que a concepção majoritária não perquira o conteúdo destas normas constitucionais, a Teoria Constitucional apresenta respostas que apelam para a legitimidade do direito, não solucionando a questão em termos de validade. ${ }^{13}$

Insistir na supremacia da Constituição olhando apenas para ela própria só permite duas interpretações: (i) a Constituição é válida e obrigatória porque ela mesma diz que é; ou (ii) a Constituição é válida obrigatória pois haveria outra norma dentro do ordenamento - uma lei ordinária, por exemplo -, que a tornaria válida e obrigatória. Em (i) há claramente uma petição de princípio, pois pressupõe aquilo que pretende provar; em (ii), se a norma pertence ao ordenamento, ela há de ser válida segundo os requisitos da Constituição, retirando dela seu fundamento de validade e não conferindo a ela fundamentação, como é necessário para resolver o dilema (Atienza e Ruiz Manero, 1998, p. 143; Struchiner, 2005, p.77).

${ }^{12}$ A referência ao termo `Constituição` abrange não somente as constituições escritas e sistematizadas em um único documento, mas também constituições não escritas, derivadas de normas costumeiras, ou de um conjunto de documentos escritos. Constituições são os conjuntos de normas que fundamentalmente explicitam o "modo como o poder político é organizado e dividido" (Gardner, 2011, p.169), ainda que contenham outras normas que não tratem apenas destas questões institucionais. Para uma análise mais detalhada, conferir os trechos iniciais do capítulo 4.1, infra.

${ }^{13}$ A questão da legitimidade da constituição ou da regra de reconhecimento é um problema que não concerne à teoria analítica do direito, mas à filosofia política. A dificuldade teórica na análise das condições mínimas de existência de um ordenamento está radicada na natureza da obrigação e autoridade política que subjaz nesta concepção, análise ausente na aproximação de Hart (Páramo Argüelles, 1984, p. 279). 
Para fugir da circularidade e do regresso ao infinito (Shapiro, 2001, p. 151) ou de uma simples imposição não fundamentada de uma resposta ("a Constituição é válida porque ela é”), deve-se acompanhar a resposta de Schauer (1995, p. 145): nada em uma constituição pode fazer dela constitucional ou inconstitucional. Constituições estabelecem os critérios de constitucionalidade e inconstitucionalidade, e assim não podem simplesmente serem consideradas elas próprias constitucionais ou inconstitucionais. O erro de muitos constitucionalistas, portanto, seria pensar que alguma coisa nas constituições permite tal juízo, caindo em um paradoxo de auto-referência.

Não se pode manter essa regressão normativa ao infinito, muito menos uma circularidade viciosa na qual conjuntos finitos de regras putativamente autorizam uns aos outros. Assim, a solução para a validade das constituições não pode estar dentro dela, no próprio plano da normatividade constitucional, nem em alguma abstração teórica ${ }^{14}$, mas fora delas ${ }^{15}$, em uma regra de reconhecimento última (ultimate rule) (Hart, [1961] 2009, p. 136). A partir daqui, portanto, o termo ‘regra de reconhecimento’ será utilizado para fazer referência a esta regramestra, última, que dá fundamento de validade para todo o sistema, distinta das demais regras de reconhecimento não-ultimas, derivadas, que estabelecem critérios de validade que não são últimos, e que serão aqui especificadas quando a elas se fizer referência neste estudo.

É a postura - a prática social relevante de reconhecimento da Constituição como tal - adotada pela sociedade frente à Constituição que a torna suprema dentro do ordenamento jurídico. Mas, estando dentro do sistema, não pode estar acima da regra social que o fundamenta. Ao contrário das posições clássicas da Teoria Constitucional (e de Bentham e Austin), que afirmam ser o

${ }^{14}$ Hart rechaça as propostas apresentadas por Hans Kelsen, cujo debate não se encontra no escopo do presente trabalho. O que importa é que a solução da norma fundamental kelseniana não é adotada no marco teórico hartiano. Ver os artigos "Kelsen Visitado" e "A doutrina Kelseniana da unidade do direito" em Ensaios sobre Teoria do Direito e Filosofia. Rio de Janeiro: Elsevier, 2010.

${ }^{15}$ Tanto a norma fundamental quanto a regra de reconhecimento têm como principal função estabelecer os critérios de validade do resto das normas do ordenamento jurídico: no entanto, o primeiro conceito é um postulado, do qual se pressupõe a validade, enquanto que a existência do segundo é uma questão empírica de fato, o que leva a Páramo Argüelles (1984, p.188) afirmar que a posição de Hart é intermediária entre Kelsen e o realista jurídico Ross. 
soberano que faz as regras, para Hart são as regras que fazem o soberano (Shapiro, 2009, p. 235).

E se o fundamento de validade da Constituição (e, consequentemente, de todo o ordenamento) está na regra última de reconhecimento, onde está o fundamento de validade e autoridade desta? Nas palavras de Jules Coleman (1991 p. 705):

Só existem três possibilidades. Primeiro, a autoridade da regra de reconhecimento pode ser ela própria uma questão da sua validade sob uma outra regra. Essa não é uma solução satisfatória já que torna a última regra mencionada a verdadeira regra de reconhecimento. Em vez de responder a questão, ela simplesmente a adia para um outro momento. Alternativamente, a autoridade da regra de reconhecimento pode depender da sua moralidade; isto é, a regra de reconhecimento é em última instância uma regra normativa cuja autoridade depende de sua verdade enquanto um princípio em alguma moralidade crítica defensável. Essa solução não funciona para o positivista pelo simples motivo de que reduz o positivismo a uma forma de direito natural. Finalmente, a autoridade da regra de reconhecimento pode consistir no fato de ser uma regra social, constituída pela prática social dos agentes relevantes, uma regra que eles aceitam do ponto de vista interno.

Trata-se, portanto, de explicar a validade do direito sem apelar para a própria validade do direito (Green, 1999, p.35). Historicamente, os positivistas explicam essa autoridade não em termos de uma moralidade substantiva (como o jusnaturalismo), mas fazendo referência a certos fatos sociais. (Coleman, 2001, pp.354-355), nos quais está calcada a noção de regra de reconhecimento última. Para Shapiro (2009, p. 239), porque a regra de reconhecimento é uma regra social ela é capaz de ser uma regra última, no sentido de que ela não existe em virtude de qualquer outra regra, mas sua existência depende unicamente de sua aceitação e sua prática. As regras primárias do ordenamento jurídico, em contraste, somente existem em virtude da (sua relação com a) regra de reconhecimento, que valida as demais normas, mas não é ela mesma validada por qualquer norma jurídica.

Deste modo, como visto, se a regra de reconhecimento está em certo sentido fora do sistema jurídico-constitucional, ela não pode ser dita válida ou inválida - validade é um conceito utilizado dentro de um sistema de normas no qual o status de uma norma depende da satisfação de critérios impostos por outra norma superior à primeira (e, de modo último, pela própria norma de reconhecimento); o uso do conceito de validade para medí-la é inapropriado (Lamond, 2013, p. 104). Ela não é válida ou inválida, mas seu uso é simplesmente aceito como apropriado. Assim como não se pode perguntar se a barra-padrão 
situada em Paris mede um metro ${ }^{16}$, não faz sentido indagar a validade da regra de reconhecimento (Hart, [1961] 2009, p.140). Sua existência é uma questão fática, o que demanda uma investigação empírica ao invés de uma análise jurídica (Schauer, 1995, p.150). Só é possível, portanto, questionar se a norma de reconhecimento de um sistema é satisfatória ou se o sistema nela baseado merece nossa adesão; tais questões, entretanto, não provém de enunciados jurídicos internos, mas de um enunciado valorativo externo (Hart, [1961] 2009, p.139).

Ela é pois o ponto em que devem cessar as indagações concernentes à validade, pois atingiu-se uma norma que oferece critérios para a avaliação da validade de outras normas, mas difere delas pelo fato de que não existe outra norma que forneça critérios para a avaliação de sua própria validade jurídica (Hart, [1961] 2009, p.174; Dickson, 2007, p. 6). Portanto, as questões de sua (a) existência, (b) validade e (c) pertencimento se colocam de modo diferente do resto das normas jurídicas: para as demais, todas essas questões são respondidas de uma mesma forma - a regra existe, é válida e pertence ao ordenamento se identificável de acordo com os critérios da regra de reconhecimento. Por sua vez, a regra de reconhecimento (a) existe em virtude do fato da aceitação e uso concordante por parte dos agentes relevantes de uns mesmos critérios de validade; (b) não é juridicamente válida ou inválida, pois validade é uma propriedade que as demais regras possuem com a regra de reconhecimento; (c) pertence ao sistema jurídico somente na medida em que é elemento da definição de sistema jurídico, não estando dentro do sistema, mas existindo com ele (Ruiz Manero, 1990, p. 120).

No que diz respeito à relação da regra de reconhecimento com o ordenamento jurídico, a regra de reconhecimento é condição de possibilidade, uma condição necessária porém insuficiente para a existência do sistema (Coleman, 2001, p.356; Arena, 2014, p.27). Hart ([1961] 2009, p.150) indica duas condições mínimas, necessárias e suficientes, para a existência de um sistema jurídico: (i) que as normas de comportamento válidas segundo os critérios últimos, sejam geralmente obedecidas pela sociedade; e (ii) que as normas secundárias, em especial a de reconhecimento, sejam efetivamente aceitas como padrões públicos comuns de comportamento oficial por parte das autoridades do

\footnotetext{
p.138)

${ }^{16}$ Pois não há superior teste de “metricidade” do que ela própria (MacCormick, 2008,
} 
sistema. Na formulação original hartiana, os cidadãos privados só precisam satisfazer a (i), e tal obediência não demanda a adoção do ponto de vista interno; enquanto isso, (ii) deve também ser satisfeita pelas autoridades do sistema. Em suma, para Hart são condições para um sistema jurídico a obediência dos cidadãos comuns às normas primárias somada aceitação pelas autoridades das normas secundárias (Hart [1961] 2009, p.151; Páramo Argüelles, 1984, p.275). A caracterização deste “ordenamento jurídico mínimo” será muito importante para o desenvolvimento de alguns argumentos centrais a este estudo, sendo foco da análise do Capítulo 3.

\section{2}

\section{Pluralidade ou unidade da regra de reconhecimento?}

Uma primeira questão que divide a doutrina se refere à existência de uma ou mais regras de reconhecimento. E aqui a divergência somente diz respeito, por óbvio, à regra de reconhecimento última: não há dúvidas a respeito da existência de uma pluralidade de normas de reconhecimento níveis inferiores, existentes em todos os sistemas jurídicos, como as que identificam um guarda de trânsito como emissor de sinais visuais e sonoros vinculantes nas vias públicas (Gardner, 2011, p.173). Ademais, como visto no tópico anterior, a existência das próprias Constituições na maioria dos ordenamentos jurídicos modernos como critérios de validade jurídica (e a relação de inconstitucionalidade nada mais seria que a inadequação a estes critérios estabelecidos nos documentos constitucionais) torna clara a existência de regras intermediárias, derivadas ou mediatas de reconhecimento.

A posição defendida originalmente por Hart aponta para a existência necessária de uma (complexa) regra de reconhecimento para cada ordenamento jurídico. Sendo a regra de reconhecimento, como anteriormente visto, condição necessária porém insuficiente para a existência de um ordenamento, afirma-se que todo sistema jurídico possui uma e apenas uma regra de reconhecimento, e que um conjunto de regras que não inclua uma regra de reconhecimento não é propriamente um sistema jurídico (Raz, 1979, p.91).

Que a regra de reconhecimento seja uma não implica que estabeleça um único critério de validade jurídica. Ela tem um caráter complexo, isto é, faz 
referência a diversos critérios últimos de validade jurídica (Ruiz Manero, 1990, p. 142; Lamond, 2014, p. 4). Nas palavras do próprio Hart (2010, p. 405), em obra posterior ao Conceito de Direito:

Insisti que a regra de reconhecimento era tanto complexa quanto de textura aberta. Complexa porque nos sistemas jurídicos modernos não apenas um critério, mas vários critérios de validade jurídica são utilizados. Assim, mesmo em um sistema "unitário" como o inglês, o direito é identificado tanto com base no precedente judicial, como nas promulgações do Parlamento.(...) A razão para falar de "uma regra”, a essa altura, é que, não obstante sua multiplicidade, esses critérios distintos são unificados por sua ordenação hierárquica.

Assim, de acordo com Hart, somente seria possível conceber a coexistência de tais critérios contidos na regra última caso haja uma ordem de precedência. Caso contrário, seria possível a existência de conflitos entre as várias regras últimas e equiparadas - eis aí um ponto que poderia ser explorado (como de fato ocorreu) por seus críticos. Hart não nega a possibilidade de conflitos entre normas válidas de acordo com os critérios da regra de reconhecimento. O que ele nega é a possibilidade de existência de conflitos insolúveis entre os critérios últimos de reconhecimento, o que levaria à afirmação não de um ordenamento, mas de diferentes ordenamentos em uma mesma localidade (Atienza e Ruiz Manero, 1998, p. 159). Se existirem duas ou mais regras últimas em disputa, que gerem na comunidade reconhecedora relevante uma divisão geral na identificação do direito válido, aí não se estaria mais falando de um ordenamento, mas de dois sistemas competindo entre si (Ruiz Manero, 1990, p. 148).

Assim, Hart apela para uma ordenação dos critérios de validade, e, portanto, para uma única regra provendo tal ranking (Gardner, 2011, p.173). Com a ordenação de critérios, Hart se resguardaria do problema de explicar como seria possível a unidade ou até mesmo a existência de um direito fundado em uma prática convergente (como será visto adiante) se a convergência fosse minada ou meramente minável por conflitos entre os critérios mais fundamentais de reconhecimento.

Seria ainda possível, em tese em sistemas não muito desenvolvidos, que a regra de reconhecimento seja lacunosa ao identificar a ordem hierárquica dos critérios, sem que isso signifique a existência de mais de uma regra (Ruiz Manero, 1990, p. 148); também o próprio Hart admite que a regra tenha, como todas as demais, uma zona de penumbra por indeterminação ou textura aberta $(2010,405)$, sem que isso destrua a identidade do sistema ([1961] 2009, p. 158). 
O escalonamento proposto por Hart, por sua vez, leva à existência de critérios superiores a todos os demais, chegando aos critérios chamados por Hart de supremos (supreme criteria) ([1961] 2009, pp.136-137):

Podemos afirmar que um critério de validade jurídica ou fonte do direito é supremo se as normas identificadas mediante referência a ele são ainda reconhecidas como normas do sistema mesmo que conflitem com outras normas identificadas mediante referência a outros critérios; enquanto estas últimas não são reconhecidas caso conflitem com as primeiras, identificadas mediante referência ao critério supremo.

Note-se que o critério supremo e a regra de reconhecimento não se confundem necessariamente. Em alguns casos, como no Reino Unido, parecem convergir: a regra de reconhecimento aponta como critério de validade para o que emana do Parlamento soberano, indicando que a atuação de um legislativo ilimitado constituiria o critério supremo de validade (Hart, [1961] 2009, p.137). No direito norte-americano, por sua vez, a muito mais complexa regra de reconhecimento coloca o direito federal acima do estadual, o direito federal constitucional acima do direito federal infraconstitucional, e as emendas constitucionais elaboradas de acordo com o Artigo V em posição superior ao texto constitucional anterior ${ }^{17}$; neste ordenamento, os critérios de validade impostos pelo Artigo V corresponderiam ao critério supremo hartiano (Shapiro, 2009, p.238).

No outro pólo deste embate encontra-se a posição da pluralidade das regras de reconhecimento. Não seriam apenas muitos os critérios, mas muitas as próprias regras. Gardner afirma que, excetuando-se os sistemas jurídicos mais rudimentares, todos os ordenamentos possuem muitas regras de reconhecimento, e os inevitáveis conflitos entre elas - o ponto sensível da tese da pluralidade ocorreriam apenas em raras ocasiões, com implicações apenas nos níveis inferiores do sistema, sem afetar a sua unidade ou existência (Gardner, 2011, p.173).

${ }^{17}$ Há diferenças no tratamento dispensado às emendas constitucionais no direito norteamericano e brasileiro, visto que no primeiro não há que se falar em inconstitucionalidade material de novas provisões constitucionais que tenham sido devidamente formuladas (de acordo com o citado Artigo V). No Brasil, como será visto, há limites formais e materiais ao constituinte reformador. 
A tese da pluralidade de regras de reconhecimento é só aparentemente uma tese hegemônica, pois nem sempre seus defensores parecem querer dizer a mesma coisa. É possível decompor basicamente em três as teses da pluralidade.

Uma primeira versão, defendida por P.M.S. Hacker (1977, p. 24), afirma a possibilidade de regras diferentes dirigidas a órgãos diferentes: certos officials aplicariam determinados critérios de validade (como, por exemplo, tribunais estaduais aplicando a legislação estadual) enquanto outros officials aplicariam outros critérios (como a atuação de uma Corte Constitucional). Na verdade, esta tese em muito se aproxima de regras de reconhecimento derivadas (não últimas), de modo que esta primeira versão, de acordo com Ruiz Manero (1990, p. 144), não conflitaria em nada com a tese da unicidade da regra última complexa defendida por Hart.

Uma segunda proposta afirmaria a possibilidade de regras últimas não incompatíveis entre si, ou seja, ordenadas e hierarquizadas. Nas palavras de Raz (1983, p. 95):

Podem haver duas ou mais regras de reconhecimento que provêm métodos de resolução de conflitos; por exemplo, a regra impondo a obrigação de aplicar certos costumes pode indicar que ela é suprema, enquanto que a regra relativa à aplicação dos precedentes pode indicar que estes são subordinados.

O problema desta versão é que ela parece ser não somente compatível com a tese da unidade, mas praticamente redundante, tendo o mesmo conteúdo significativo que falar, como Hart, de uma única regra última que contêm diversos critérios hierarquizados (Ruiz Manero, 1990, p. 145). Afirmar a existência de duas ou mais regras de reconhecimento, cada uma delas indicando de maneira mutuamente consistente a hierarquia relativa de seus critérios é o mesmo - apenas dito de outra forma - que falar em uma única regra com dois ou mais critérios organizados hierarquicamente (Atienza e Ruiz Manero, 1998, p. 159).

Por fim, há a tese defendendo a possibilidade de uma pluralidade de regras últimas incompatíveis entre si: há de se distinguir a antinomia entre os critérios últimos de validade (incompatível com a tese de Hart) da antinomia entre as normas identificadas mediante os critérios materiais e formais - esta compatível com a versão hartiana (Ruiz Manero, 1990, p. 147). Meras incompatibilidades entre as normas identificadas por meio dos critérios de validade são absolutamente comuns e resolvidas dentro mesmo do sistema mediante o processo interpretativo e aplicativo das normas (normalmente com o auxílio de critérios 
também identificados direta ou indiretamente pela regra última, como os chamados cânones interpretativos). Somente uma incompatibilidade entre os próprios critérios de validade seria insustentável a partir da tese da unidade, e tem como principal desvantagem o ônus argumentativo contra o questionamento levantado nos casos de radical e profunda divergência na aplicação dos critérios mesmos de validade, solúvel apenas adotando-se a afirmação de que aí não mais existiria um ordenamento, mas sistemas em competição.

É portanto possível falar em regras de reconhecimento de modo compatível com a tese da unidade da regra última de reconhecimento sem cair na redundância de reformular a tese da unidade com o mesmo conteúdo significativo e sem falar em uma regra última somada a várias regras de reconhecimento não últimas, que representam apenas critérios derivados de validade (Ruiz Manero, 1990, p. 124). Para tanto, deve-se reafirmar o caráter complexo próprio da regra última de reconhecimento, admitindo-se que contenha vários critérios de identificação do direito sem que isso signifique que haja um único critério último do qual derivem os demais (como o exemplo do direito inglês, em que costume e precedente estão subordinados à legislação, mas dela não derivam seu status de direito) (Ruiz Manero, 1990, p. 123).

Em resumo do que foi exposto nesta seção: para além da tese da unidade da regra de reconhecimento (que para todos os fins é aqui adotada), há diferentes versões advogando a pluralidade de regras de reconhecimento: (i) pluralidade de regras de reconhecimento derivadas (não últimas); (ii) pluralidade de regras últimas hierarquizadas entre si: (iii) pluralidade de regras últimas de reconhecimento que estipulem de forma antinômica distintos critérios de validade. Como indicado, só seria incompatível com a proposta de Hart uma versão forte da tese (iii), de modo que as antinomias afetariam aos critérios centrais de validade jurídica - e que esses casos não se poderia falar de um mesmo sistema jurídico, mas casos patológicos em que diferentes sistemas competem para ser o sistema jurídico do Estado (Ruiz Manero, 1990, pp. 15-16). 
2.3

A natureza da regra de reconhecimento

Talvez a questão mais debatida e com o maior número de propostas, a ontologia da regra de reconhecimento será abordada aqui de um modo que - ao menos se pretende - seja simples e claro. Não serão avaliados pormenores metafísicos, em investigações detalhadas a respeito de cada uma das muitas propostas de compreensão da natureza da regra de reconhecimento.

A investigação abordará questões que parecem simples ou sedimentadas na tradição positivista hartiana, mas que podem se revelar interessantes: seria a regra de reconhecimento realmente uma regra? Em que sentido de regra? Quais as práticas sociais - qual a natureza de tais práticas - que determinam a regra de reconhecimento?

Hart caracteriza as regras jurídicas como um caso especial de regras sociais que derivam sua existência de práticas sociais (Páramo Argüelles, 1984, p. 423). A regra de reconhecimento não seria diferente e se fundaria em uma prática social de aceitação de determinados critérios de validade jurídica por certas pessoas (o grupo reconhecedor relevante), possuindo, portanto, uma natureza dupla: (i) normativa, que fundamenta o conceito de validade, ao servir como referência fundamental dos enunciados jurídicos internos dos sujeitos que a utilizam para reconhecer o direito; (ii) fática, que fundamenta o conceito de eficácia, ao ser um conceito unido inexoravelmente à prática jurídica, um fato observável do ponto de vista externo (Páramo Argüelles, 1984, p. 255). Para Shapiro (2009, p. 239), a regra de reconhecimento é "social” em dois sentidos: primeiro, ela existe e tem o conteúdo que tem devido exclusivamente a certos fatos sociais, que certos membros de um grupo adotam o ponto de vista interno em relação ao padrão de condutas e o utilizam para avaliar a validade de normas; em segundo lugar, ela é social pois ela define o padrão para o grupo. Membros não aceitam a regra apenas para si, mas tratam o padrão imposto pela regra como o modo adequado de identificação do direito naquela sociedade. Sua existência, pois, é assegurada por conta da sua aceitação e prática.

Mas a regra de fato é regra ou ela se confunde com a prática que lhe é subjacente?

Por um lado, Schauer (1995, pp.150-151 e 1998, p.66) defende que seria ligeiramente enganador pensar em uma regra de reconhecimento, pois não há 
nada na prática de reconhecimento do direito que requeira que o método de reconhecimento seja a aplicação de algo que lembre uma regra escrita em um ato normativo comum aos sistemas jurídicos desenvolvidos. Seria, pois, mais adequado conceituar a dimensão reconhecedora do direito como contendo um conjunto de práticas que distinguem o direito do não-direito. Para Galligan (2007, p.96), a regra de reconhecimento seria uma "metáfora" para a aceitação do sistema jurídico, como um conjunto de práticas sociais sobre o que conta como direito em certa sociedade.

Entretanto, para Coleman ${ }^{18}$ (2001, p.358), Shapiro (2011, p.103) e Arena (2014, pp.42-43), regras e práticas pertenceriam a categorias metafísicas distintas e seria um erro de categoria (Shapiro, 2011, p. 103) reduzir uma a outra: regras seriam objetos abstratos e práticas eventos concretos: assim, seria mais adequado, em vez de falar que as regras sociais são práticas sociais, afirmar que sua existência depende da existência de uma prática social. Regras são padrões que guiam condutas, não as próprias condutas (Shapiro, 2011, p. 103). Uma regra social poderia suceder a uma prática social no sentido de que é logicamente impossível que a regra mude sem que a prática também mude (Arena, 2014, p.44), mas isso não significaria que a regra se confunde com a prática. Qual é, então, a relação entre regra de reconhecimento e a prática social a que tanto Hart se refere? Parece que a prática é condição de existência da regra de reconhecimento, que passa a existir como uma regra que guia comportamentos somente se é praticada (Coleman, 2001, p.358; Dickson, 2007, p.3), ou, ao menos, que a prática é condição de inteligibilidade da regra (Coleman, 1991, p.708, nota 9) ${ }^{19}$.

Para Coleman (2001, pp.359-360), ser a prática uma condição de existência da regra não implica que o seu conteúdo é completamente determinado

${ }^{18}$ A posição de Coleman já vinha sendo construída desde "Negative and Positive Positivism”, inicialmente publicado em 1982 e republicado em 2003 (em Markets, Morals and the Law, p.344, nota 12): “como Hart e Dworkin usam o termo, uma regra social é uma prática, e a natureza da prática determina o escopo e a extensão do dever que ela impõe”, mas que "nem toda regra de reconhecimento é uma regra social neste sentido”, pois (i) o conteúdo da regra pode ser especificado anteriormente à existência da prática, como o caso da Constituição Americana, que precede (temporal e logicamente) a prática de sua aplicação; e (ii) tomando um conceito mais amplo de regra social, em que uma regra pode assim ser considerada caso sua existência ou autoridade dependam, parcialmente, na existência de uma prática social.

${ }^{19}$ Entender a prática convergente (ou melhor, a convergência da prática) como uma razão para aceitação da regra é o cerne da tese convencionalista, cuja compatibilidade com as posições defendidas (ao menos na versão original) n’O Conceito de Direito são questionadas por Green (1999) e Dickson (2007), e que será discutida adiante (2.6.3.). 
pela prática. Se fosse assim, qualquer descrição que capturasse o alcance da convergência seria a própria regra, algo como “o que quer que o grupo reconhecedor relevante faça, eles estão seguindo a regra cujo conteúdo lhes indica que façam exatamente o que eles já fazem” ${ }^{20}$. Isso seria no mínimo uma explicação pouco elucidativa, além de fazer convergir o escopo da obrigação com a própria prática convergente, de modo que nenhuma ação convergente deixaria de satisfazer a regra, o que torna difícil falar propriamente em uma regra que guia condutas. Além do mais, se a prática determina completamente o conteúdo e as obrigações que a regra impõe, não haveria margem para desacordo no grupo reconhecedor quanto aos critérios de reconhecimento, abrindo-se espaço para críticas como as de Dworkin (Coleman, 2001, pp. 382-383, nota 11).

Estes problemas parecem advir de uma falta de compreensão do significado do tratamento da regra de reconhecimento como uma regra jurídica e social. Quanto ao primeiro caráter, ela parece ser jurídica apenas num sentido “fraco”, na medida em que é "uma característica que define todo o sistema juríidico, de tal modo que seja, portanto digna de ser ela própria chamada direito” (Hart [1961] 2009, p. 144). Ela é elemento da definição de sistema jurídico, não estando dentro do sistema, mas existindo com ele (Ruiz Manero, 1990, p. 120).

Quanto a ser uma regra social, de um modo geral pode-se afirmar que regras jurídicas são espécie do gênero regras sociais em dois sentidos: tanto por governar conduta humana em sociedade e, principalmente, por dever sua origem e existência exclusivamente a práticas humanas (MacCormick, 2008, p.31). Especificamente quanto à regra de reconhecimento, são possíveis duas concepções: a primeira, criticada acima, afirma que a regra de reconhecimento é regra social no sentido de que seu conteúdo é inteiramente determinado pela prática social convergente aceita no ponto de vista interno; a segunda reconhece que a regra pode não ser constituída inteiramente pelas práticas sociais convergentes, mas que sua autoridade depende da existência de uma prática social 156?):

${ }^{20}$ Parece ser esta a tese adotada pela maioria, tal como explicada por Himma (2003, p.

em qualquer sistema jurídico conceitualmente possível, o que os agentes públicos conscientemente tratam como sendo o critério válido é o critério válido. Enquanto agentes públicos - incluindo juízes - individualmente podem presumivelmente errarem quanto aos critérios de validade, isto simplesmente nao é possível, se a Tese Convencionalista é verdadeira, para os agentes públicos do sistema jurídico, considerados coletivamente, estarem errados de um modo geral quanto a critérios de validade. 
de aceitação da regra como autoritativa (Coleman, 1991, p.708, nota 9). Somente nesta segunda interpretação, afirma Coleman, poderia o conteúdo da regra ser diferenciado da mera descrição da prática convergente. Entretanto, ao colocar a prática convergente como condição de inteligibilidade a fim de evitar "problemas epistêmicos” para a definição do conteúdo da regra (1991, p. 708, nota 9) e afirmar que a prática social não determina mas firma (fixes) a regra de reconhecimento (2001, p. 361), Coleman também está sujeito a críticas, pois sob o ponto de vista hermenêutico, do teórico que quer desvendar qual a regra de reconhecimento aceita em uma determinada sociedade, não parece haver diferença no potencial explicativo de sua versão para a concepção tradicional. Seria possível cogitar de enfraquecer ainda mais o claim referente à conexão entre prática e regra e admitir que a prática serve não para constituir ou determinar, mas apenas para desvendar a regra de reconhecimento que subjaz na sociedade, atendendo ao caráter epistêmico aludido por Coleman. Mas esta afirmação também não está imune de críticas, pois parece desvirtuar a noção de que a prática seria condição de existência da regra.

Uma outra importante nota a ser feita envolve estabelecer a regra de reconhecimento não apenas sob um aspecto meramente semântico, como um critério conceitual, que seria incapaz de guiar comportamentos. Como visto anteriormente, a regra de reconhecimento parece impor certas obrigações de seguir os critérios por ela apontados na identificação do direito. O fato de a regra de reconhecimento parecer ter um caráter constitutivo deve ser levado em conta nesta análise ontológica, mas não pode colocar uma sombra no igualmente importante caráter normativo da regra.

De acordo com a premissa aqui adotada de que é necessária uma concepção que dê conta do dever de aplicar o direito como um dever jurídico, e portanto de natureza não moral, a regra de reconhecimento deve ser entendida como uma norma genuína, e não como uma mera norma definicional (Ruiz Manero, 1990, p. 142); essas concepções, por não darem conta do aspecto normativo da regra de reconhecimento em nenhum de seus dois sentidos (nem a normatividade do direito por ela reconhecido nem a normatividade da própria regra) não serão aqui adotadas. Por outro lado, deve-se ter em conta o seu caráter constitutivo: é a regra de reconhecimento de cada ordenamento jurídico que constitui as normas reconhecidas como jurídicas (Burazin, 2014, p. 3), que 
constitui os fatos institucionais jurídicos nas respectivas sociedades, é com ela que se pode falar propriamente de um ordenamento jurídico e não de um mero aglomerado de normas primárias. Note-se que as regras constitutivas também podem possuir uma dimensão regulativa, que, neste aspecto, daria conta da normatividade do direito, impondo a obrigação no grupo reconhecedor relevante de aplicar as normas identificadas por meio dos critérios da regra de reconhecimento.

Assim, não é incompatível falar em uma regra bidimensional (regulativa e constitutiva) e parece ser o caso de, por ora, pensá-la como uma regra que apenas existe em virtude de uma prática. Mas qual o tipo de regra e qual a natureza desta prática? Nos próximos tópicos essas questões serão aboradadas, começando com o tipo de regra indicado por Hart para a regra de reconhecimento, e avançando nos tópicos subsequentes algumas propostas de compreensão da regra de reconhecimento como uma regra social que irão basicamente divergir quanto à ontologia da prática social subjacente à regra.

\subsection{1 \\ Regra Costumeira}

Segundo Hart, a regra de reconhecimento seria "na verdade uma forma de norma jurídica consuetudinária que existe apenas quando é aceita e praticada nas operações de identificação e aplicação das leis pelos tribunais” ([1961] 2009, p.330 e 1982, p.156). Hart foi seguido por outros autores nesta concepção, tomando a regra como um costume surgindo da prática judicial de aplicação concordantemente dos mesmos critérios últimos de validade jurídica somada à atitude de aceitação deste padrão como o correto (Hacker, 1977, p. 23; Raz, 1979, p. 92; Ruiz Manero, 1990, p. 14; Green, 1999, p.35; Atienza e Ruiz Manero, 1998, pp. 156-157; Gardner, 2011, p.188). Ela imporia nesses atores o dever de usar, para fundamentar suas decisões, as regras identificadas a partir dos critérios de validade jurídica que a própria regra de reconhecimento estabelece (Raz, 1979, p. 93; Ruiz Manero, 1990, p. 120).

Bentham (1997, pp. 182-84; Gardner, 2012, p.66) diferencia costumes in foro e costumes in pays, sendo os últimos costumes da comunidade em geral, ou melhor, quaisquer costumes que não fossem in foro. Para Hart e os demais, a 
regra de reconhecimento seria um costume in foro, um costume judicial (Gardner, 2011, pp.174; Lamond, 2013, p.119). Esta distinção será relevante para os propósitos deste trabalho, quando, no Capítulo 3, for ofertada uma nova interpretação da regra de reconhecimento como um costume in pays.

A natureza de norma costumeira é compatível com a distinção feita anteriormente entre prática e regra, de modo que é preciso aqui também diferenciar entre a prática e a sua consideração como obrigatória - isto é, entre os dois elementos tradicionalmente identificados nos costumes: usus and opinio (Atienza e Ruiz Manero, p. 157). Também dá conta do fato de que a regra de reconhecimento é uma regra praticada, não necessariamente enunciada (Hart, [1961] 2009, p.131; Gardner, 2012, p.70).

Sua caracterização como costume não deve levantar a objeção de que, sendo regra em um certo sentido jurídica, ela pertenceria ao ordenamento jurídico, o que não estaria de acordo com a análise anteriormente feita. Como explica Gardner (2011, pp. 184-185):

[Regras de reconhecimento] são achadas nos costumes dos agentes públicos responsáveis pela aplicação do direito, mas disso não se segue que elas devam (apesar de poderem) identificar o costume desses agentes públicos como fonte do direito. Neste sentido, elas estão acima do direito, não são parte dele. Isso nos permite reconhecer que existem regras últimas de reconhecimento que estão, por assim dizer, acima da constituição, e ao mesmo tempo afirmar que não há direito acima da constituição. Direito Constitucional é o mais alto que o direito pode chegar. Correspondentemente, uma constituição escrita pode existir mesmo que exista uma regra costumeira de reconhecimento acima dela, uma que a identifique como constituição e vincule os aplicadores do direito, qua aplicadores do direito, a seguí-la.

Finalmente, a caracterização como costume também daria conta do caráter dúplice - constitutivo e regulativo - da regra de reconhecimento. Como foi visto, a regra de reconhecimento, na qualidade de fundamento ultimo de validade do sistema jurídico, confere o caráter jurídico às normas por ela reconhecidas, cumprindo uma função ontológica (Burazin, 2014, p.3). Mas não é só: ela além de constituir certas regras como jurídicas, também constitui (ainda que não completamente - ou, como Hart menciona, “de modo embrionário” ${ }^{21}$ o próprio conjunto de regras como um sistema jurídico, em oposição a um aglomerado de

\footnotetext{
${ }^{21}$ Recorde-se que, para Hart, um sistema jurídico completamente amadurecido somente passa a existir com o advento das três normas secundárias ([1961] 2009, p. 122).
} 
regras primárias, um “conjunto de elementos isolados e desconexos”, tal qual Hart afirma ([1961] 2009, p. 123).

\subsection{2}

\section{A Teoria das Regras Sociais como Práticas}

A concepção original de Hart, apresentada n’O Conceito de Direito, é denominada Teoria das Regras Sociais como Práticas (TRSP, ou, no original, Practice theory of Rules). Uma regra social que os sujeitos $\mathrm{x}$ devam $\mathrm{p}$ nas condições $C$ existe em uma sociedade $S$ se e somente se as seguintes condições ocorram: A maior parte dos sujeitos x em S regularmente p nas condições $C$ (a regra é regularmente seguida pelos membros da respectiva sociedade); na maior parte dos casos que algum sujeito $\mathrm{x}$ não $\mathrm{p}$ nas condições $\mathrm{C}$, ele encontra uma reação crítica ao seu desvio (desvios da regra recebem críticas); as críticas não são elas mesmas alvo de críticas, e os sujeitos que criticam o desvio não são criticados por criticar; membros de S usam uma linguagem normativa (“um x deve p em C” e “é o direito que se deve p em C”) para justificar suas ações de p nas condições C e para justificar as críticas (Raz, 1999, pp.52-53; Green, 1996, p.1693; Marmor, 2001a, p.2).

É este o formato de práticas e regras sociais que vem sendo utilizado, até agora, como base explicativa no presente trabalho. Esta teoria, ao tentar explicar como regras derivam de práticas, está aberta a algumas críticas, em especial a que a acusa de não conseguir dar conta do caráter normativo das regras ${ }^{22}$.

Afirma-se que a Teoria das Regras Sociais como Práticas não é capaz de explicar como a regra social de reconhecimento constitui uma razão para ação dos juízes e agentes públicos, os grupos inicialmente apontados por Hart como relevantes na prática de reconhecimento (Marmor, 2001a, p. 4). Ela, entre outras falhas, não conseguiria demonstrar a relação entre a conviç̧ão dos participantes a respeito da existência de um dever e o fato da existência uma prática social de observância desse dever. Seria possível que juízes aplicassem regularmente os

\footnotetext{
${ }^{22}$ Para maiores detalhes, conferir as críticas feitas por Raz no seu "Practical Reason and Norms" (1999, pp.52-58) e Dworkin ${ }^{22}$ em “O modelo de regras II” (2002, pp.73-125), explicitada por Arena (2014, pp. 46-53) e Marmor (2001a).
} 
mesmos critérios e cressem ser seu dever aplicá-los sem que ao mesmo tempo essa crença esteja vinculada com a existência da regularidade de comportamento. Dworkin (2002, p. 85) assinala que é necessário distinguir dois casos em que ambos os elementos (regularidade e crença) estão presentes, a saber, as práticas concorrentes (por convicção independente de cada um dos agentes) das práticas convencionais (que consideram o fato desse acordo como parte essencial das razões que os levam a afirmar a existência dessa regra).

A Teoria das Regras Sociais como Práticas, mesmo se restrita ao âmbito da convencionalidade, deveria para Dworkin ser abandonada pela da impossibilidade de conciliação da existência de uma regra social de reconhecimento que guie a atividade de identificação do direito com desacordos na prática de identificação (Dworkin, 2002, pp. 86, 87; Shapiro, 2007, p. 25; Marmor, 2011, p. 75): se uma regra social é constituída por uma convergência de comportamento, não há espaço para controvérsias, para desacordos, que podem (e costumam) surgir quer em regras de reconhecimento sistematicamente controversas $^{23}$, quer em regras eminentemente incontroversas mas que são potencialmente controversas (Coleman, 2003, p. 19).

As críticas, entretanto, são improcedentes: há que se distinguir dois tipos de desacordos: disputas a respeito do conteúdo da regra de reconhecimento (disputas de conteúdo) e desacordos que pressupõem consenso a respeito do conteúdo da regra mas ocorrem no âmbito de sua implementação (disputas de aplicação) (Coleman, 2003, p. 20; Shapiro, 2007, p. 26); Marmor (2001a, p. 6) fala em controvérsias referentes à existência da regra e controvérsias referentes à formulação da regra. Os desacordos levantados por Dworkin seriam desacordos de aplicação (ou de formulação, para Marmor), e, portanto, compatíveis com o conceito de prática social da teoria hartiana. Em verdade, o próprio Hart parece ter adotado esta linha de resposta no pós-escrito d’O Conceito de Direito ([1961] 2009, p.333), ao afirmar que a regra de reconhecimento não pretende determinar completamente o resultado jurídico em casos particulares, de modo que qualquer questão jurídica surgida em qualquer causa possa ser resolvida pelo simples recurso aos critérios ou testes fornecidos pela norma. Na verdade, a função da

\footnotetext{
${ }^{23}$ Devido à suposta adoção do critério de pedigree para dar conta de standards de conteúdo eminentemente moral (Dworkin, 2002, p. 64).
} 
norma seria apenas definir as condições gerais que devem ser satisfeitas pelas decisões jurídicas corretas nos modernos sistemas jurídicos. Na maior parte das vezes, a norma faria isso oferecendo critérios de validade (de fonte ou de obediência a valores ou princípios morais substantivos). Hart ([1961] 2009, p334) afirma que "juízes podem em casos específicos discordar quanto ao atendimento dos critérios. Podem estar de acordo quanto à pertinência dos critérios, mesmo que discordem sobre o que os critérios exigem em casos particulares ${ }^{24}$.

Foi no pós-escrito que Hart reviu sua concepção, no que parece ser um abandono parcial da Teoria das Regras Sociais como Práticas, ao menos como uma teoria geral, passando a afirmá-la como um caso especial aplicado a regras convencionais (Green, 1999, p.39), e que seria esta a natureza da regra de reconhecimento: "uma regra alicerçada numa forma convencional de consenso judicial” (Hart, [1961] 2009, p.344). Leslie Green (1999) e Julie Dickson (2007) afirmam ter ocorrido, a partir da segunda edição d'O Conceito de Direito, uma "virada convencionalista” (conventionalist turn) no positivismo jurídico, seguindo a indicação da natureza convencional da prática jurídica de reconhecimento. As diversas propostas teóricas que surgiram nesta seara serão objeto do próximo tópico.

\subsection{3 $\mathrm{O}(\mathrm{s})$ convencionalismo(s)}

Como uma resposta às críticas feitas por Dworkin à concepção da chamada Teoria das Regras Sociais como Práticas, descrita no tópico anterior, Hart parece adotar uma nova relação - inexistente na versão original - entre a prática convergente do grupo reconhecedor relevante e as razões que esse grupo tem para aceitar a regra de reconhecimento como vinculante (Dickson, 2007, p. 10). Assim, a Teoria das Regras Sociais como Práticas não seria uma teoria geral aplicável a qualquer regra social, mas apenas explicativa de uma subcategoria das regras sociais, a saber, as convenções, que se destacam das demais regras sociais

\footnotetext{
${ }^{24}$ Para uma análise mais detida da crítica de Dworkin e uma defesa do positivismo hartiano, ver Shecaira, 2012.
} 
pelo fato de que a "obediência geral de um grupo a elas está entre as razões que levam os membros individuais do grupo a aceitá-las” ([1961] 2009, p. 330; Coleman, 2001, p.372; Dickson, 2007, p. 3; MacCormick, 2008, p.137; Galligan, 2007, p.86). É neste sentido - e somente neste sentido, como expressamente indicado no parágrafo seguinte ("minha descrição das normas sociais é, como Dworkin também sustentou corretamente, aplicável apenas às normas que são convencionais no sentido que acabo de explicar" ([1961] 2009, p. 330)) - que Hart “adota” o convencionalismo. Algumas páginas adiante ([1961] 2009, p. 344) reitera o compromisso com esta tese convencionalista no sentido que a regra de reconhecimento é alicerçada numa "forma convencional de consenso judicial” no sentido em que “a concordância de outros indivíduos contribui para a aquiescência de cada um”.

Essa concessão levou muitos seguidores de Hart a desenvolver um corpo teórico que expandisse a noção da regra de reconhecimento como uma regra convencional, isto é, determinada por uma prática social cuja natureza é de uma convenção (Marmor, 2001a, p. 4; Arena, 2014, pp.18, 159), de forma a manter a capacidade do positivismo para dar conta do fenômeno da normatividade do direito sem abrir mão das suas fundações sociais (Coleman, 2001, p.357).

Pode-se afirmar que, em geral, para se falar em uma convenção, uma prática social deve atender às seguintes "condições de convencionalidade" (Marmor, 2009, pp 2-12; Arena, 2014, pp. 70):

a) Condição de convergência: membros do grupo $G$ realizam a ação A cada vez que se apresenta a ocasião $\mathrm{O}$, tendo $\mathrm{O}$ se apresentado com certa frequência ou pelo menos mais de uma vez e que seja possível voltar a apresentar-se;

b) Condição de dependência ${ }^{25}$ : a razão de seguir a convenção deve ser constituída, ao menos em parte, pelo fato de que existe uma prática comum; ou seja, a conformidade dos demais indivíduos à regularidade ingressa nas razões para conformar-se à regularidade, mas não exclui outras razões para seguir a convenção. A condição de dependência possui uma versão fraca (Marmor, 2009, pp. 5-8) e uma versão mais “forte”, que demanda que entre as

${ }^{25}$ É a condição de dependência que permite diferenciar convenções de meras regularidades de comportamento, seja por exigências técnicas (como por exemplo acender a luz para trabalhar de noite) ou casos em que se considera estar seguindo normas morais (como, por exemplo, a norma moral que obriga o respeito aos pais) (Arena, 2014, p.87). 
razões para conformação esteja o fato de que os demais agentes o fazem por esta mesma razão ${ }^{26}$. A dependência neste último caso é recíproca ou reflexa (Arena, 2014, p.86);

c) Condição de Arbitrariedade: representada pela existência de um modo distinto de configurar as convenções que seja ao mesmo tempo possível, praticável, incompatível com o escolhido, bem como pela possibilidade de alteração da conformidade, que denotam uma arbitrariedade na escolha da solução (Arena, 2014, pp. 87-91).

A primeira dessas tentativas convencionalistas procurou identificar a regra de reconhecimento em uma convenção no sentido atribuído pelo filósofo David Lewis $^{27}$, como soluções (não derivadas de um acordo), em situações de interação estratégica, para problemas de coordenação recorrentes envolvendo um conflito parcial de interesses (Marmor, 2001b, p. 200; Arena, 2014, p. 112). Entretanto, os problemas de coordenação propriamente também possuem condições de existência: (i) relativa coincidência de interesses (de modo que cada um deve se beneficiar mais da cooperação que da não cooperação); (ii) preferências mutualmente condicionadas (ações são preferidas a outras se e somente se os outros agentes também as preferirem); (iii) existência de uma alternativa (Postema, 1982, p.174; Shapiro, 2002, p. 389; Arena, 2014, pp.102-103).

Um dos problemas das convenções de coordenação é o fato de que ausentes as condições que permitem a formação de um problema de coordenação também serão ausentes as condições que permitem o surgimento de uma convenção (Arena, 2014, p.114). Assim, dois problemas parecem minar a viabilidade da regra de reconhecimento como fundada em uma convenção coordenativa: em primeiro lugar, o direito não parece ser um caso de conflito parcial de interesses que gere um problema de coordenação; além disso, regras de reconhecimento não parecerem ser arbitrárias no sentido colocado por Lewis (Marmor, 2001a, p. 9; Dickson, 2007, p. 18; Shapiro, 2002, p.392). Coleman (2001, p. 374) apresenta outras razõs para o abandono das convenções coordenativas: o fato de que os participantes da atividade de reconhecimento não

26 E que, portanto, necessita de mais uma condição de convencionalidade, o conhecimento comum da existência da convenção entre os membros do grupo (Arena, 2014, pp.93-96).

${ }^{27}$ Convention: A Philosoplty Study (1969). 
parecem possuir preferências ex ante de modo que a atividade de reconhecimento em si configure um conflito parcial de interesses, e que tais convenções não parecem dar conta de todos os tipos de razões que as autoridades públicas têm para agir como os demais. Green, (1999, pp. 43 e 51) por sua vez, foca em argumentos que pretendem demonstrar que tais convenções não dão conta do caráter normativo do direito e nem explicam convenções que não possuem autoridade.

Assim, com a falibilidade das convenções coordenativas, a maioria dos autores ${ }^{28}$ precisou migrar para outras posições. Enquanto alguns como Shapiro, Coleman e Adler adotaram o conceito desenvolvido por Bratman de Atividades Cooperativas Compartilhadas (objeto do próximo subtópico), Marmor desenvolveu, baseando-se na ideia de regras constitutivas avançada por Searle, uma concepção de convenções constitutivas.

As convenções constitutivas podem ser definidas como regularidades de comportamentos que adquirem seu significado a partir de regras (constitutivas) que definem uma prática social e o modo de participar nela (Arena, 2014, p.132). Caracterizam-se por sua capacidade de criar e definir novas formas de comportamento, como jogos, formas de arte, cerimônias sociais como o casamento, etc. (Marmor, 2009, p. 31; Dickson, 2007, p. 19; Galligan, 2007, pp.86-87; Arena, 2014, p.118). Esse tipo de prática social é (ao menos parcialmente) constituído por regras sociais constitutivas, que, além de constituir a prática e (parcialmente) regular muitos de seus aspectos fundamentais, também definem ou constituem, em parte, os valores associados com a prática em questão e definem o discurso avaliativo a ela aplicável (Marmor, 2009, p. 36; Dickson, 2007, p. 20; Arena, 2014, pp.118-119). Definir e constituir significam aqui que determinadas ações adquirem certo valor enquanto são realizadas dentro da prática constituída pela convenção. Os valores são internos à prática e seguir a regra é contingente a estar imerso no contexto dos valores definidos pela prática. Por exemplo, não há valor algum fora do contexto do jogo de xadrez em mover o bispo na diagonal; o valor em seguir a regra só é perceptível dentro do jogo (Marmor, 2009, p.39; Arena, 2014, p.119).

\footnotetext{
${ }^{28}$ Lagerspetz parece ser o único a permanecer com as convenções coordenativas.
} 
Note-se que as convenções constitutivas são atividades constituídas por um conjunto de regras constitutivas (Arena, 2014, p.120), que devem ser entendidas não como regras que definem práticas isoladas, ações particulares, mas como um sistema de regras que dá condições de possibilidade de práticas sociais (Marmor, 2009, pp. 34-35; Arena, 2014, p.132). Assim, a relação entre regra e prática é invertida. Se na Teoria das Regras Sociais como Práticas e nas convenções coordenativas era a prática social que caracterizava a regra, nas convenções constitutivas é o conjunto de regras constitutivas que constitui as práticas sociais. Marmor (2001a, p. 18) enxerga nelas um sentido de convencionalidade na medida em que "regras convencionais podem constituir uma prática social somente se as regras são de fato seguidas (...) somente convenções praticadas são convenções”. Essa concepção, entretanto, não coincide com o sentido de convencionalidade adotado por Hart n'O Conceito de Direito (que parece ser, na verdade, uma concepção “fraca” da condição de dependência). Mais ainda, Marmor (2001, p. 18) parece rejeitar o sentido de convencionalidade adotado por Hart ao afirmar que não necessariamente as razões para seguir um conjunto de convenções constitutivas consistem no fato de que outros também a seguem. Para Hart, como visto, o fato da convergência deve ser necessariamente ao menos parte das razões para seguir a regra, para que se possa falar em uma regra convencional.

Isto leva a outro problema para Marmor. Ao tratar da regra de reconhecimento como regra constitutiva, ele afirma que (2001a, p. 33):

Regras de reconhecimento, como qualquer outro tipo de convenção constitutiva, apenas definem o que a prática é. Elas apenas dizem o que conta como direito na nossa sociedade. Como tal, elas também definem a validade jurídica das normas; isso implica em dizer que elas definem as regras do jogo. Isso deixa em aberto a questão de por que as pessoas devem praticar o direito de seu país; por que devem jogar o jogo (...) Se juízes, advogados ou leigos possuem qualquer razão moral ou de outro tipo para jogar o jogo, é uma questão totalmente separada (...) essas razões não podem ser prescritas pelas próprias convenções sociais.

As razões para “jogar o jogo” da regra de reconhecimento não seriam nem parcialmente determinadas pela prática convergente dos demais atores no grupo relevante. Esse trabalho é feito pelas razões primárias ou subjacentes (Marmor, 2001a, p. 26). Apesar de ser uma posição bem próxima da desposada por Hart na versão original d’O Conceito de Direito (Dickson, 2007, p. 26), há diferenças, principalmente no que diz respeito às implicações para a normatividade das 
convenções constitutivas: estas seriam apenas "condicionalmente mandatórias”, isto é, elas apenas afirmam um dever, apenas configuram razões para agir se o agente está comprometido em participar da prática constituída pela convenção (Marmor, 2001a, p. 30).

Aplicando-se ao caso da regra de reconhecimento, Marmor (2001a, p. 31) afirma que o seu convencionalismo constitutivo não explica a razão porque o grupo reconhecedor relevante está obrigado a seguir o direito; ele apenas explica que, se o grupo reconhecedor relevante quiser seguir o direito, então ele deve aplicar os critérios de validade jurídica oferecidos pela regra de reconhecimento. Sendo a regra de reconhecimento condição necessária de existência do direito em determinado lugar (ou seja, condição necessária de existência de ordenamentos jurídicos), o convencionalismo constitutivo não explica por que deve-se ter um ordenamento jurídico, mas somente explica o que conta como direito em uma determinada sociedade.

Como boa parte das regras constitutivas (que possuem também um caráter regulativo, responsável por sua normatividade), a regra de reconhecimento possuiria caráter duplo, por um lado constituindo o que é o direito (ao cumprir suas funções epistêmica, validatória e sistêmica) e por outro impondo deveres nos sujeitos para aplicar os critérios de validade por ela indicados (Marmor, 2011, p. 82).

Mais: a regra de reconhecimento seria uma convenção superficial em um contexto de convenções profundas.

Parece haver convenções que constituem a especificação ou instanciação de outras normas convencionais: por exemplo, a convenção que se deve vestir terno num casamento é instanciação da convenção que se deve mostrar respeito pelos noivos, que, por sua vez, é instanciação da convenção que se deve mostrar respeito pelos outros membros do grupo (Arena, 2014, pp.141 e 142).

Em situações em que só há convenções superficiais, não poderia ocorrer um erro ou desacordo generalizado quanto ao seu conteúdo (pois assim não se poderia falar em convergência); já nas situações em que há cadeias com convenções profundas, é possível um desacordo na maioria da comunidade a respeito das aplicações corretas e incorretas da regra convencional, pois o que importa é a orientação pelo fundo normativo compartilhado (as convenções mais profundas). Entretanto, tais desacordos possuem limites, não podem ser difusos, 
pervasivos (Arena, 2014, p.154-155). Profundidade não é sinônimo de constitutividade; apesar da maioria das convenções profundas ser de convenções constitutivas, é possível haver convenções profundas (intermediárias) de coordenação, como a convenção de coordenação que indica o lado pelo qual se deve trafegar na rua, que pode ser instanciada caso as vias possuam mais de uma pista, para que é necessário uma convenção meramente superficial indicando por qual pista trafegar, sendo a convenção coordenativa original uma convenção profunda intermediária (Arena, p.157).

Exemplos no direito de convenções profundas básicas são as que definem, segundo Marmor, as diferentes famílias de sistemas legais (common law e civil law), que podem ser consideradas como alterantivas (Marmor, 2009, pp.172-173; Arena, 2014, p.189). A regra de reconhecimento certamente não é uma convenção profunda básica; ela é uma convenção constitutiva profunda intermediária ou meramente superficial, através da qual se manifestam certas convenções profundas (Arena, 2014, p.189). Nas palavras de Marmor (2009 p.171):

Entre as razões gerais para se ter direito e as convenções locais que determinam o que conta como direito em um determinado sistema jurídico, há camadas intermediárias de convenções profundas, que constituem os principais blocos da construção dos sistemas jurídicos. As convenções profundas do direito são tipicamente manifestadas nas convenções superficiais de reconhecimento que são específicas às sociedades e seus ordenamentos jurídicos.

\section{4 \\ Reconhecer é aceitar}

Neste tópico, pretende-se sucintamente abordar algumas questões relativas à aceitação da regra de reconhecimento e a terminologia a ela referente, como o que se quer dizer quando se fala em aceitação, a diferença entre os pontos de vista interno e externo, e a (des)necessidade de perquirir os motivos para aceitação. Não é do propósito deste trabalho (e nem há espaço para tanto) uma detalhada análise de todas as controvérsias que permeiam o tema, nem uma revisão da extensa bibliografia na área, mas apenas prosseguir desvendando os alicerces conceituais do instituto da regra de reconhecimento.

Hart ([1961] 2009, p. 329) conceitua aceitação como uma “atitude normativa específica” em relação a certos padrões de conduta, consistindo na 
disposição permanente dos indivíduos de aceitar esses padrões de comportamento tanto como orientações para sua própria conduta futura como padrões críticos capazes de legitimar exigências e várias formas de pressão em prol da obediência às normas.

O que significa tomar comportamentos como guias de conduta para si e para os demais, como razão e justificação para ação? É necessário inserir o contexto em que Hart desenvolve o conceito de aceitação, qual seja, o da diferenciação entre normas e hábitos, que basicamente se resume à necessidade de aceitação do padrão de comportamento nas regras e a desnecessidade de tal aceitação nos hábitos: enquanto para a existência de hábitos bastaria a convergência de comportamento, para que se possa realmente falar em uma regra social é preciso que ela seja aceita - ou seja, que (i) desvios da regra sejam vistos como erros e portanto sujeitos a críticas, e as ameaças de desvio sofram pressão no sentido da obediência; (ii) que o próprio desvio seja visto como uma boa razão para a crítica e que esta seja considera justificada ou legítima tanto pelos que criticam quanto pelos que são criticados; e (iii) que a regra seja tomada em seu aspecto interno (Hart, [1961] 2009, pp.74-75). Mas, como será visto, (i) e (ii) fazem parte da atitude crítico-reflexiva característica do ponto de vista interno (iii), de modo que falar em aceitação pode ser considerado um "atalho” para referir-se ao ponto de vista interno, isto é, para indicar que membros da sociedade em questão possuem a atitude crítico reflexiva em relação ao padrão de condutas em questão (Lamond, 2013, p.102).

Note-se que Hart ([1961] 2009, p.74) considera o termo como sofrendo de uma vagueza de grau, ao afirmar que "não se sabe exatamente quantos membros do grupo precisam usar o comportamento habitual, da maneira que citamos, como padrão para suas críticas, nem com que frequência e por quanto tempo precisam fazê-lo”. É importante reconhecer que não há limites fixos para identificação de uma regra social e que esta é mais uma tarefa de sociologia jurídica do que de teoria do direito ${ }^{29}$, motivo pelo qual o teórico não precisa se engajar nela sob uma perspectiva puramente conceitual.

MacCormick (2008, p.49), por sua vez, afirma que o termo 'aceitação' parece cobrir duas atitudes: “aceitação deliberada/voluntária” (willing

${ }^{29}$ Ainda que se considere dentro do projeto teórico de Hart o exercício de uma “sociologia jurídica descritiva”, como a que se pretende desenvolver no capítulo 4 deste trabalho. 
acceptance), em que o agente não prefere apenas a observância do padrão, mas o prefere como constituindo uma regra que supõe ser sustentada por uma preferência comum, compartilhada; e a “mera aceitação” (Mere acceptance), um “caso fraco” de aceitação desejada, em que agentes estão cientes da existência de outros agentes em atitude de aceitação desejada, cientes que a regra se considera aplicável a eles e que, portanto, possuem razões para (a) se conformar à regra para evitar as críticas justificadas e (b) preferir que a regra seja aplicada de modo geral, a todos os demais que a regra se mostra aplicável. Neste último caso (de mera aceitação) o autor escocês afirma que os agentes estão "relutantemente aceitando", ou - em termos mais esclarecedores - "aceitando sem aprovar inteiramente” a regra. Isto demonstra que falar em aceitação não requer uma aprovação ou endosso moral do agente em relação à regra. Ao tema se retornará em breve.

Também não é necessária uma conformidade unânime dentre os participantes do grupo reconhecedor, sendo possível existir uma regra mesmo quando uma minoria se recuse a encará-la como padrão de conduta (Hart, [1961] 2009, p.75). O principal aqui é que a não conformidade à regra seja acompanhada de algum tipo de tentativa de excusa ou justificação por parte do agente que desvia, e na ausência dessas exista algum tipo de vergonha, culpa, ou ao menos de ter como legítimas as críticas feitas (Hacker, 1977, p. 15; Páramo Argüelles, 1984, p. 329). Hart mantém um conceito não meramente formal (que seria o simples reconhecimento de que a norma é válida e usada como modelo de comportamento), mas como uma experiência interior ${ }^{30}$ dos destinatários que não depende de uma valoração moral do conteúdo das normas (Páramo Argüelles, 1984, p. 329).

Apesar de o próprio Hart não ter explorado este caminho de investigação, alguns autores que se baseiam em Hart compreendem que a aceitação não parece ser uma questão de “tudo-ou-nada” (Hacker, 1977, p.16; Galligan, 2007, p.94), como é o conceito legal de validade (ou uma regra é válida ou não é). Em

\footnotetext{
${ }^{30}$ Não é do propósito do presente trabalho discutir a ontologia desta experiência interior dos participantes do ordenamento jurídico - se uma crença, uma capacidade psicológica dos seres humanos em adotar uma prática ou padrão de comportamento (Coleman, 2001, p.368) ou qualquer outra perquirição estados mentais dos agentes. Parece bastar partir da premissa que os participantes adotam a postura crítica-reflexiva mencionada por Hart (e destacada por MacCormick) quando da descrição do ponto de vista interno.
} 
contrário, haveira uma transição gradual entre os dois extremos. Seria possível, pois, falar em níveis de aceitação (Galligan, 2007, pp. 94-96).

Também para o agente que não aceita a regra, a rejeição não implica em uma violação uniforme e universal, e sua conformidade é sempre dependente das considerações a respeito dos incentivos (vantagens percebidas) e desincentivos (sanções, entre outros) para seguir ou não a regra (Hacker, 1977, p.16). Aceitação, portanto, poderia ser parcial, contigente; determinadas regras sociais demandariam e encorajariam uma aceitação mais completa e inequívoca que outras - o que se perceberia tanto num nível de regras primárias (como nos distintos graus de aceitação das variadas regras de etiqueta e regras morais) quanto no de regras secundárias, como se vê, por exemplo, das diferentes posturas que as sociedades tomam em relação a suas constituições (escritas ou não). Não se poderia pensar que todos os participantes do grupo adotam a mesma postura sob a mesma perspectiva: por mais que o juiz, o policial, o assistente social, o advogado e o cidadão engajado compartilhem um compromisso com a manutenção do sistema jurídico e a aplicação do direito com ele identificado, suas atitudes devem em certa medida variar, sendo pois compreensível que divirjam em tais tarefas de reconhecimento e aplicação do direito (Galligan, 2007, p. 95). No caso da regra de reconhecimento, não deveria surpreender se participantes tão diversos dessem formulações diferentes da regra que eles seguem, ainda mais se demandados a especificá-la em detalhes. Assim, não se poderia perder de vista que seria possível um certo grau de desacordo nas formulações, sendo mais importante o entendimento comum aos participantes dos aspectos básicos da regra - ainda que não consigam enunciá-la precisamente -, compreensão esta que pode ser percebida no seu comportamento convergente frente a casos claros e paradigmáticos, ou, nas palavras de Coleman (2001, p.361), no compartilhamento de um "quadro de interação" (framework of interaction).

Quanto ao ponto de vista interno, este é concebido como a atitude prática ${ }^{31}$ de aceitação de uma regra, indicando que o sujeito está disposto a guiar e avaliar condutas em referência ao padrão (Shapiro, 2006, p.1157); é o ponto de vista de quem não se limita a registrar e predizer condutas (como com hábitos e regras

\footnotetext{
${ }^{31}$ Pontos de vista podem ser práticos (interno e externo) e teoréticos (hermenêutico e behaviorista). V. Shapiro, 2006, p. 1160.
} 
descritivas $^{32}$ ), mas de quem usa as regras como critérios ou pautas para valorar sua conduta e dos demais (Páramo Argüelles, 1984, p.215). Ele é associado a uma atitude crítico-reflexiva (ou crítica e reflexiva (Hart, [1961] 2009, p.75)) e apresenta um elemento de cognição, representado pelo termo 'reflexivo', aliado a um elemento volitivo, representado pelo termo 'crítico' (MacCormick 2008, p. 47). O primeiro daria conta da noção de 'padrão' de comportamento, da capacidade de agentes perceberem uma correlação abstrata entre certos atos e circunstâncias e de avaliar condutas em referência a estes padrões gerais e abstratos; o último diz respeito à preferencia que o ato seja praticado nas circunstâncias devidas, preferência esta que pode (e parece de fato ser para o caso da regra de reconhecimento, como será visto na análise da sua convencionalidade) ser condicional à aceitação do mesmo padrão pelos demais agentes. Para que ocorra, não é necessário que existam 'sentimentos' de obrigação, não há necessidade de um elemento emocional (MacCormick, 2008, p. 48): o que é necessário é que haja a 'atitude crítico-reflexiva' frente a certos modelos de comportamento que formam pautas ou critérios de conduta comuns, e que ela se desenvolva na forma de críticas (que inclui a autocrítica), expressadas caracteristicamente na terminologia normativa 'eu devo', 'dever', 'você tem que’, ‘correto', ‘incorreto’ etc. (Hart, [1961] 2009, p.76; Páramo Argüelles, 1984, pp.203-204; Shapiro, 2006, p. 1163).

A ele se contrapõem os pontos de vista externos, que englobam a deliberada rejeição à regra (prático externo, do chamado homem mau de Holmes), o ponto de vista teorético hermenêutico do observador que nota a existência e prática de uma regra pelo grupo, e até o ponto de vista externo extremo, característico dos sujeitos que não percebem que a regularidade se deve à aceitação de uma regra (não possuem, portanto, o elemento de cognição), e do cientista natural (ponto de vista teorético behaviorista) preocupado apenas em estabelecer regularidades de comportamento humano (MacCormick, 2008, p. 51, Shapiro, 2006, p. 1161). O problema deste ponto de vista é metodológico, pois não dá conta do aspecto subjetivo das condutas humanas (MacCormick, 2008, p. 52).

\footnotetext{
${ }^{32}$ Para a diferença entre regras prescritivas e descritivas, v. Schauer, 1991, pp.1-3.
} 
O ponto de vista interno possui alguns papéis na teoria hartiana: (i) ele especifica o tipo de atitude que um sujeito pode ter em respeito ao direito; (ii) ele constitui uma das principais condições de existência de regras sociais e jurídicas; (iii) ele provê a base para uma semântica dos enunciados legais; e (iv) ele dá conta da inteligibilidade da prática e do discurso jurídico (Shapiro, 2006, p.1158). Para Coleman (2001, pp.385-386, nota 27), além de uma condição de existência do direito e de ser parte da explicação da normatividade do direito, de como regras sociais podem se tornar razões, sua principal função é epistêmica: é um indicador de que indivíduos tratam o direito como provedor de razões, indicando a existência de comportamentos governados por normas e tornando inteligível a linguagem normativa.

Em especial referencia à regra (social) de reconhecimento, sobressai o fato de ser o ponto de vista interno uma condição de existência da regra: não há regra de reconhecimento sem comportamento convergente e sem a atitude (compartilhada) em relação ao padrão de comportamento de identificação e aplicação do direito, que permite dizer que tal comportamento é governado por uma regra social de reconhecimento (Coleman, 2001, p.362 e 384). O próprio uso da regra de reconhecimento já implica a adoção do ponto de vista interno quanto à identificação do direito: expressões como “o direito dispõe que...”; “a lei diz que...” implicam uma aceitação compartilhada da regra de reconhecimento enquanto padrão de critérios a ser utilizado na atividade de identificação e aplicação do direito. Por sua vez, sob o ponto de vista externo se enuncia apenas o fato de que outros aceitam o direito de determinada forma, como por exemplo na expressão “no Brasil se reconhece como direito...” (Páramo Argüelles, 1984, pp.245-246).

Um último ponto merece mais detalhada consideração: aceitação não implica necessariamente um endosso ou aprovação moral do conteúdo da regra, nem exige uma motivação específica para fazê-lo. O ponto de vista interno não é necessariamente um ponto de vista moral (Shapiro, 2006, p.1162). Se, por um lado, o simples medo de sanções por desobediência é insuficiente para gerar a atitude crítica e reflexiva típica do ponto de vista interno, Hart ([1961] 2009, p. 262) expressamente afirma que aqueles que voluntariamente aceitam o sistema jurídico não precisam considerar-se moralmente obrigados a aceitá-lo, de modo que 
a lealdade das pessoas ao sistema pode, na verdade, se basear em muitas considerações diferentes: cálculos do interesse a longo prazo; consideração desinteressada por outras pessoas; uma atitude irreflexiva herdada ou tradicional, ou o simples desejo de agir como os demais.

É preciso, pois, distinguir o fato da aceitação das possíveis razões que levam a ela. As pessoas possuem diferentes motivos para aceitar, mas, ao fazê-lo, reconhecem a obrigação de seguir a regra. A questão referente a ser determinada regra ou conjunto de regras aceito em determinado grupo é uma questão ligada a fatos sociais, a como essas pessoas agem e veem suas ações (e dos demais) em relação à regra, e não a questões de moralidade crítica, o que as pessoas pensam da regra (Galligan, 2007, p.51). O que interessa à teoria do direito é o fato da aceitação, não as razões para tanto ${ }^{33}$. Nas palavras de Galligan (2007, p.89):

Se você joga tênis, ao entrar no jogo você aceita as regras como vinculantes (...) o mesmo se aplica ao direito: se você é um agente público (e também se você é um cidadão), você aceita um conjunto de regras jurídicas para lidar com certos assuntos. Isso significa tomar as regras como vinculantes, o que, por sua vez, significa adotar o ponto de vista interno em relação a elas. A normatividade ou obrigatoriedade das regras é explicada deste modo: ao entrar em uma atividade, você aceita as suas regras como vinculantes, e isso se aplica ao tênis, palestras ou ao direito

Isso não significa que as pessoas não possam ter razões para aceitar as regras: elas possuem sim razões, mas estas não são determinantes para o fato de que a regra é aceita. Parece não ser do escopo da teoria do direito perquirir tais razões (Marmor, 2011, p. 58), mas da psicologia social, da antropologia jurídica, da filosofia política. Como notou Hart, as razões podem ser as mais variadas, baseadas em questões de moralidade crítica, um compromisso com os bens sociais que resultam da manutenção de um sistema jurídico ou outras razões até mesmo de interesse próprio. Aparentemente, em ordens jurídicas modernas, questões ligadas à legitimidade política (Kramer, 1999), à garantia de certos “bens sociais” (segurança e estabilidade, prestações positivias de bem estar, direitos humanos, restrição de atividades por meio de regulação e limitação do governo) sejam a principal razão pela qual as pessoas aceitam as diversas regras de reconhecimento dos diversos ordenamentos, e que sem tais bens os sistemas jurídicos modernos

33 Os teóricos do direito que adotam posições convencionalistas podem divergir parcialmente desta afimação, pois consideram que a convergência a respeito da prática social configura uma razão dentre as quais o grupo reconhecedor relevante aceita a regra de reconhecimento. $\mathrm{O}$ fato de os demais atores dentro do grupo aceitarem a regra é, portanto, razão e condição necessária porém não suficiente para a aceitação da regra (Dickson, 2007, p. 13). 
não subsistiriam (Galligan, 2007, p.94). Mas isso é, obviamente, algo contingente e não necessário a uma análise conceitual que pretenda - como pretendeu Hart dar conta do fenômeno jurídico em sua maior amplitude possível (Dickson, 2007, p.8).

Assim, mesmo que uma sociedade em geral adote (e a adoção não precisa ser unânime nem inquestionada) uma regra de reconhecimento pelos motivos mais esdrúxulos possíveis (como a Dama do Lago que faz de Arthur rei em Monty Python e o Cálice Sagrado ${ }^{34}$ ), a questão é afirmar esse sistema como jurídico. Então, como visto, a questão se existe uma regra de reconhecimento é diferente da questão se a regra de reconhecimento existente tem uma base empírica ou moralmente forte (sound). A existência da regra de reconhecimento é uma coisa, sua desejabilidade ou moralidade é outra. No exemplo do Rei Artur, a base para adoção da regra de reconhecimento é empírica e moralmente errada, mas nada disso retira seu status (empírico) de regra de reconhecimento e sua função de critério (Schauer, 1998, p.75). Deste modo, pessoas em sistemas jurídicos moralmente detestáveis podem abominar as regras que eles são obrigados a aplicar, mas isso não deixaria de satisfazer os critérios de existência de um sistema jurídico (Wacks, 2005, p. 83).

Em resumo: o direito é possível por meio da interdependência entre uma convergência e um certo tipo de atitude em relação ao padrão de reconhecimento de um determinado conjunto de critérios de identificação do material jurídico. O elemento atitude é representada pelo conceito de aceitação - um “atalho” para indicar que aquela regra ou conjunto de regras são tomadas no seu ponto de vista interno, ou seja, que indivíduos pautam e avaliam sua conduta e a dos demais com

\footnotetext{
${ }^{34}$ ARTHUR: I am your king!
}

OLD WOMAN: Well, I didn't vote for you.

ARTHUR: You don't vote for kings.

OLD WOMAN: Well, how did you become king, then?

ARTHUR: The Lady of the Lake, her arm clad in the purest shimmering samite, held Excalibur aloft from the bosom of the water to signify by Divine Providence ... that I, Arthur, was to carry Excalibur ...That is why I am your king!

DENNIS Look, strange women lying on their backs in ponds handing out swords ... that's no basis for a system of government. Supreme executive power derives from a mandate from the masses, not from some farcical aquatic ceremony.

ARTHUR Be quiet!

DENNIS You can't expect to wield supreme executive power just 'cause some watery tart threw a sword at you!

ARTHUR Shut up! 
base no conjunto de regras, ocorrendo pressão para que comportamentos se adequem às regras e críticas tidas como justificadas (tanto por quem critica quanto por quem sofre a crítica) nos casos de desvio da regra. Essa atitude, composta de um elemento cognoscitivo e um elemento volitivo, reflete um caráter normativo das regras sociais, que, quando visto sob a perspectiva da regra social que mais interessa ao direito - a regra de reconhecimento - pode servir como explicação para a normatividade do próprio direito.

Entretanto, falar em aceitação não significa necessariamente falar na aprovação moral das regras que são aceitas, pois é necessário diferenciar o fato social da aceitação dos motivos ou razões que as pessoas possuem para aceitar. Por mais esdrúxulas e moralmente incorretas que possam ser as razões para aceitação de determinada regra de reconhecimento, não impedem que se reconheça a sua existência enquanto fato social.

\section{5 Quando ocorre o reconhecimento?}

Uma das críticas promovidas por Hart a Austin diz respeito ao fato de que a teoria imperativa não daria conta do problema da "persistência do direito" ([1961] 2009, p.81), ao fato de que sua teoria somente permite uma análise momentânea dos sistemas jurídicos. Cabe então verificar como se dá o tratamento de tais questões pela doutrina hartiana, e, mais especificamente, responder a uma importante questão: quando ocorre o reconhecimento - apenas no momento da fundação do sistema jurídico e em outros momentos relevantes de alteração ou durante toda a vida do sistema? Em outras palavras, seria a prática de reconhecimento momentânea ou permanente?

Parece que independentemente da ontologia da prática de reconhecimento adotada deve-se considerar sua continuidade no tempo. Hart deixa algumas indicações n’O Conceito de Direito a este respeito, como quando afirma que “a aceitação de uma norma por uma sociedade num dado momento não assegura a continuidade de sua existência. Pode haver uma revolução: a sociedade pode deixar de acatar a norma.” ([1961] 2009, p.78). Hart também deixa clara esta posição quando trata dos casos patológicos de sistema jurídico, ao abordar situações possíveis em que podem ocorrer transições entre sistemas, com a 
alteração da regra de reconhecimento ([1961] 2009, pp. 151-152). Deste modo, o direito brasileiro no tempo $T$ é determinado pela prática (seja ela uma convenção, uma atividade cooperativa compartilhada, um costume) em $T$ convergente no grupo reconhecedor relevante, e o direito brasileiro em $T^{\prime}$ determinado pela prática em $T$ ' , no que Adler (2006, p. 796 ) chama de “presentismo” (no mesmo sentido, Raz, 1980, p.192; Gardner; 2011, p.177).

De fato, a questão não parece apresentar muitos problemas em uma análise abstrata e até mesmo nos casos de ordenamentos jurídicos que sofrem (como o brasileiro) de constantes alterações constitucionais, que desvelam alterações em sua regra mestra. Ela vai ganhar interesse nos locais em que a prática jurídica evoca fontes do direito seculares, sejam elas costumeiras (como no direito inglês), escritas (como a Constituição Norte-Americana de 1787), ou ainda certo tipo de entendimento ou interpretação (como o recurso constante, em certas teorias interpretativas americanas, à visão dos founding fathers a respeito da própria Constituição). Nesses casos, em que as vozes do passado possuem certa força jurídica no presente, é preciso indagar qual a fundamentação teórica para tanto. Mas aqui também a resposta intuitiva é de fato mais adequada: é o presente que determina o status e a força do passado. Nas palavras de Schauer e Alexander (1997, p.1370):

Pode, claro, ser o caso que uma sociedade adote como sua norma fundamental ou regra última de reconhecimento o princípio que todas as questões a respeito do conteúdo de suas normas constitucionais, incluindo as regras de como interpretar a constituição e quem deve fazê-lo, devem ser decididas com recurso às visões dos escritores da constituição, às visões das maiores figuras políticas da época da fundação, às práticas aceitas ao longo da história do país. Mas mesmo este princípio de referência histórica iria dever sua validade política e status como direito à aceitação atual, e não a sua importância histórica. O presente, e não o passado, decide se o passado é relevante. Consequentemente, é somente o presente que pode constituir uma ordem legal para a população, e a questão do que é ou não parte do sistema jurídico - o que de fato possui status legal e o que deveria ter status legal - somente pode ser decidida de modo não histórico.

Não há, pois, como se fixar um momento específico para o qual deve-se olhar a fim de identificar a regra de reconhecimento que dá o fundamento de validade do ordenamento jurídico, ainda que momentos relevantes - como a promulgação de constituições escritas - possam ser tratados como tal pela teoria constitucional, por exemplo. Na verdade, é essa dinâmica de continuidade que dá sentido ao processo de alteração da regra, abrindo a possibilidade de que a regra 
reconheça como jurídicas normas que antes não teriam o mesmo status. Neste sentido afirmam Alexander e Schauer (2009, p. 181, nota 23):

Uma regra de reconhecimento ou prática de reconhecimento é sempre calcada na aceitação atual pelo grupo reconhecedor relevante. E apesar de ser possível que a Constituição é aceita hoje por conta do processo de ratificação de 1788, é mais provável que sua aceitação contemporânea esteja fundada em outros fatores, e não seria suspensa por uma descoberta de que o processo de ratificação foi inconsistente com as especificações do Artigo VII - assim como é improvável que a aceitação contemporânea da $14^{\mathrm{a}}$ Emenda como direito válido dependa da sua ratificação ter ocorrido de acordo com o Artigo V (que dispõe sobre o processo de emenda constitucional).

Assim, no exemplo americano, mesmo que tenha ocorrido um problema formal que pudesse colocar (sob a ótica do direito constitucional) em xeque a validade jurídica da $14^{\mathrm{a}}$ emenda ou da própria Constituição americana, a prática atual de aceitação (unânime) dessas normas jurídicas pelo grupo reconhecedor relevante da sociedade americana (seja quem for - juízes, agentes públicos ou toda a população) sobrepôs-se demonstrando que a regra de reconhecimento deste ordenamento fora alterada. Do mesmo modo, qualquer tentativa de questionar a validade da Constituição de 1988 - como por exemplo afirmando que ela não é mais que uma emenda à constituição anterior, por ter sido sido assim convocada sucumbe à prática convergente da sociedade brasileira de reconhecer o documento assinado em 5 de outubro de 1988 como norma superior dentro do ordenamento jurídico brasileiro.

Essa discussão leva ao próximo tópico, que brevemente abordará a possibilidade e condições de alteração da regra de reconhecimento.

\section{6}

\section{Alteração da regra de reconhecimento}

Como toda regra social, por definição, a regra de reconhecimento pode ser alterada ao longo do tempo, bastando que ocorra a alteração da prática dos sujeitos relevantes. A alteração pode ser parcial ou completa, rápida ou lenta, violenta ou pacífica. O que importa, como visto, é que o fato social da prática do grupo reconhecedor relevante mude com o tempo.

Note-se que não é necessário que ocorra uma mudança formal no ordenamento jurídico (em especial constitucional) para que ocorra alteração na 
regra de reconhecimento; pelo contrário, mudanças nos fundamentos sociais de um determinado sistema jurídico somente podem ocorrer em termos factuais ou, na expressão de Schauer, pré-legais (Schauer, 1995, p.148). Parece ser o caso que mudanças relevantes no material jurídico-constitucional sejam na verdade reflexos de mudanças mais profundas nos pressupostos factuais do direito.

Os casos mais comuns (e que chamam mais atenção) envolvem rupturas totais violentas, irregulares. Revoluções e demais experiências de político-sociais de transformação bem sucedidas costumam ser acompanhadas de alterações na prática social que fundamenta o direito local, mesmo que não ocorra alteração no direito vigente na ordem anterior. Afirma Hart (2010, p. 408):

Após uma ruptura revolucionária como a imaginada por Fuller, é forçoso que sempre fique incerto, por algum tempo, quais os critérios que serão finalmente usados para definir o direito. É preciso que se passe algum tempo antes que uma uniformidade suficientemente na prática de tribunais, legisladores e outros oficiais se desenvolva e permita que se ê uma resposta a essa questão. Mas quando as coisas se acalmarem, pode ser claro que, além de aceitar a "promulgação de Brutus" como marca de uma lei válida, os tribunais também reconheçam grande parte do direito privado promulgada sob o antigo regime. Em qualquer descrição completa dos critérios utilizados pelos tribunais após a ruptura revolucionária para definir o direito, a antiga legislação teria que ser especificamente mencionada eo nomine. Se não tivesse havido revolução, ela teria sido identificada com base na provisão geral que qualificava a sucessão initerrupta de legisladores. Após a revolução, portanto, a validade da antiga legislação passa se basear numa regra de reconhecimento diferente da anterior.

Porém nem todas as rupturas internas são bem sucedidas - ao menos não imediatamente. Pode haver situações em que dois ou mais grupos dentro da comunidade reconhecedora relevante (seja ela composta apenas por juízes, pelos officials ou por todo o povo) apresentem práticas convergentes distintas e competitivas entre si. São casos em que há uma disputa pelo domínio político e jurídico de um determinado território e sociedade e que propostas distintas competem pela adesão da maioria da comunidade reconhecedora, democraticamente ou não. Alguns exemplos famosos envolvem o caso sulafricano citado por Hart $^{35}$, em que legislativo e judiciário divergiram profundamente a respeito de suas competência e poderes, criando uma "oscilação interminável entre duas interpretações sobre a competência do poder legislativo e, portanto, sobre os critérios de validade do direito” ([1961] 2009, pp. 157-158) e

\footnotetext{
${ }^{35}$ Harris vs. Dönges ([1952] 1 TLR 1245).
} 
casos pós-revolucionários em que o novo sistema proposto pelas forças revolucionárias tenta sobrepujar o antigo sistema jurídico, como os casos da Rodésia do Sul, Paquistão, Uganda (Schauer, 1995, p. 151, nota 17) e o recente caso da Criméia, antigo território ucraniano que em 2014 declarou independência da Ucrânia e, em votação popular, optou por ser anexada à Rússia, mesmo sob as alegações de ilegalidade do procedimento pela comunidade internacional ${ }^{36}$. As grandes questões nesses casos de severas crises institucionais e revoluções são pois solucionadas pelo balanço político e de forças (militares inclusive) (Gardner, 2011, p.168).

Mas nem só de revoluções sangrentas e transições pacíficas vive o teórico hartiano que se engaja no esforço de sociologia descritiva em ordenamentos jurídicos locais. Podem também ocorrer revoluções ordeiras e pacificadas - como no desmanche da União Soviética e a independência de mais de uma dezena de novas repúblicas, ou até mesmo a ilegalidade da Constituição Norte-Americana face aos Artigos da Confederação ${ }^{37}$, caso não se considere os framers de 1787 como usurpadores ou revolucionários dentro da própria revolução (Schauer, 1995, p.154).

As "patologias” possíveis a um sistema jurídico não param por aí: apesar de que toda alteração irregular e bem sucedida das fontes supremas do direito (como as inicialmente vistas) acompanham a alteração da regra de reconhecimento, nem todas as mudanças regulares e ordeiras implicam em continuidade da regra: por vezes, como diz Hart ([1961] 2009, p. 154), um sistema jurídico emerge de um novo após uma operação cesariana. Foi o que ocorreu com algumas colônias britânicas ${ }^{38}$, que obtiveram sua independência por meio de alterações jurídicas internas ao esquema constitucional britânico - por de 2014

${ }^{36}$ http://www.bbc.com/news/world-middle-east-26248275. Acesso em 28 de dezembro

${ }^{37}$ Os Artigos da Confederação (o pacto que formava a Confederação composta pelos treze Estados recém independentes da Inglaterra) demandavam, em seu artigo XIII, ratificação de qualquer alteração ao documento pelas treze legislaturas estaduais. Quando reunido na Philadelphia para emendar os Artigos, o Congresso da Confederação decidiu abandoná-los em favor de um novo documento - a Constituição de 1787, que em seu artigo VII demandou apenas a ratificação por nove das treze legislaturas estaduais. Uma vez ratificada por New Hampshire, o nono estado, a Constituição passou a valer como direito válido e supremo (law of the land), mesmo - ou melhor, apesar de - sua ilegalidade em relação aos Artigos da Confederação. Algum problema? Não para os americanos e nem para um teórico hartiano.

${ }^{38}$ E o que provavelmente ocorreria na Escócia, caso a população escocesa tivesse optado pela independência do Reino Unido no referendo de 18 de setembro de 2014. 
meio de atos do Parlamento. Uma vez consolidada a independência, a regra de reconhecimento aceita nas colônias já não mais incluía qualquer referência aos poderes do Parlamento britânico, mesmo que o poder constituinte local tivesse sido originalmente criado por um ato do Parlamento (Hart, 1961] 2009, pp. 154156; Atienza e Ruiz Manero, 1998, p. 147).

Cabe, por fim, falar de alterações parciais na regra de reconhecimento. Há que se distinguir alterações interiores à constituição (governadas pelas regras secundárias de alteração) e alterações exteriores à constituição. Assim como a substituição de constituições ocorre fora delas, com a alteração da regra de reconhecimento, também a substituição de partes da constituição pode ocorrer fora dela com a alteração parcial da regra de reconhecimento. Nas palavras de Schauer (1995, pp.156-161):

Como a Constituição repousa nas fundações extraconstitucionais que formam a regra de reconhecimento, então a Constituição necessariamente pode ser emendada pelo processo extraconstitucional de alteração social e política dessas fundações extraconstitucionais. (...)

Porque as constituições devem sua "constitucionalidade" a condições política e logicamente antecedentes, o processo de alteração constitucional pode também ocorrer em um outro nível, quando essas condições política e logicamente antecedentes são elas próprias alteradas. Porque essas condições antecedentes não são elas mesmas legais ou constitucionais (...) é necessariamente o caso que constituições são sempre sujeitas a alterações pela mudança - emenda - nas práticas dos cidadãos, nas práticas dos agentes públicos, e nas práticas dos seus juízes.

A alteração nas práticas que deflagram a regra de reconhecimento - nos pressupostos que fundamentam a constituição, para usar a terminologia de Schauer - pode levar a vários tipos de alterações constitucionais ${ }^{39}$. Pode acrescentar normas não escritas no texto constitucional (com, por exemplo, o surgimento de um nova prática, um novo costume); retirar a validade de uma determinada norma (caso o grupo reconhecedor relevante passe a entender que a norma é obsoleta diante de uma nova realidade e que passe a tratá-la como nula apesar de não ter ocorrido nenhuma alteração no texto constitucional ou sequer a declaração de uma "mutação” constitucional) (Schauer, 1995, pp.156-157), ou, ainda, mudar de uma interpretação literal para uma não literal a respeito de

39 Infelizmente, detalhar a interessante relação entre alterações na regra de reconhecimento e alterações formais e informais da constituição não cabe neste espaço e não está no escopo deste estudo, mas será objeto de futuros trabalhos. 
normas constitucionais (o que parece ter sido o caso norte-americano), ou de um entendimento de exclusividade e inalterabilidade das cláusulas de emenda para um tratamento mais flexível, permitindo a emenda das normas constitucionais referentes ao próprio processo de emenda (Schauer, 1995, p.160). 


\section{3 \\ Alguns problemas persistentes}

A análise dos aspectos conceituais continua neste capítulo com o estudo de quatro questões: a distinção da regra de reconhecimento para as demais regras secundárias; a normatividade da regra de reconhecimento; a aceitação da regra de reconhecimento; e a identidade do grupo reconhecedor relevante.

O objetivo é mostrar que a perspectiva canônica parece apresentar certa dificuldade em dar conta satisfatoriamente dos ordenamentos jurídicos modernos. Ao fim do capítulo, pretende-se oferecer uma proposta de solução que passa por considerar o grupo reconhecedor não somente nos officials ou juízes, mas englobando também o povo.

Para que fique claro, ao falar-se em perspectiva/formulação/concepção canônica se está fazendo referência às condições mínimas colocadas por Hart ([1961] 2009, p.150) para a existência de um sistema jurídico (também chamado de “ordenamento jurídico mínimo”): (i) a aceitação da regra de reconhecimento por juízes/officials; (ii) o cumprimento das normas validadas pela regra de reconhecimento pelo povo.

\section{1 As regras secundárias e uma (im)possível distinção}

Este tópico propõe-se a traçar duas distinções: a primeira entre regras primárias e secundárias, e a segunda das regras secundárias - de reconhecimento, alteração e adjudicação - entre si.

Hart inicialmente associa normas primárias a normas que canalizam condutas, impõem deveres e obrigações, e normas secundárias a normas que outorgam poderes públicos e privados, permitem a adição, extinção ou modificação de normas primárias, e controlam sua aplicação (Hart, [1961] 2009, p.105). A distinção entre regras de competência e regras que impõem deveres jurídicos não é nova, juristas continentais usavam antes de Hart (Hart, 2010, p. 403), mas foi a sua utilização de tais conceitos no bojo da crítica feita à teoria imperativa de Austin que deu conferiu notoriedade à abordagem de Hart. 
Contudo, o seu modo de classificação de regras é objeto de muitos ataques (Lee, 1968, p.561; Hacker, 1977, pp.18-22; MacCormick, 2008, pp.130-134; Raz, 1979, pp.177-179; Ruiz Manero, 1990, p.100, Shapiro, 2009, p.235, Perry, 2009, p.296). De fato, Hart parece utilizar muitos critérios, e de forma confusa ou ambígua (MacCormick, 2008. pp.130; Gardner, 2013, p.86), sendo sua distinção taxada de vaga e imprecisa por MacCormick (2008, p.134).

Raz (1983, p. 177), por sua vez, aponta para uma confusão mais profunda cometida por Hart: ao identificar tipos de regra com tipos de funções sociais que as regras perfazem, Hart torna menos inteligível a distinção entre as funções primárias de facilitar acordos privados e a função secundária de criação do direito, além de obscurecer a importante função das normas que impõem obrigações em perfazer funções secundárias de criação do direito e levar os leitores desavisados a tomar a regra de reconhecimento como uma regra que confere poderes. Tudo isso seria causado pelo fato de que a classificação de regras como primárias e secundárias serve a dois propósitos incompatíveis na formulação original hartiana: ela é por vezes vista como uma distinção entre tipos normativos, e por vezes entre funções sociais das regras.

Segundo notam MacCormick (2008, p.131) e Ruiz Manero (1990, p.100), são três os critérios classificatórios utilizados por Hart: (i) de acordo com o caráter deôntico das regras; (ii) entre regras que envolvem ações envolvendo movimentos ou mudanças físicas e as que levam à criação ou variação de deveres e obrigações; e (iii) entre regras "parasitas” e regras “não parasitas” - regras parasitas seriam as metarregras, regras sobre outras regras. Hacker (1977, p.20) aponta três modos de classificação das regras:

i. pelo seu caráter deôntico - se são regras que impõem deveres ou se conferem poderes (o tema será melhor explorado no tópico respectivo à normatividade da regra de reconhecimento);

ii. pela natureza da norma-ato que a regra guia - se é um ato de exercício de poder ou não; e

iii. se a regra pretende ou não regular o escopo, a incidência, a aplicação ou a existência de outra regra.

O problema, como nota Hacker (1977, p.20), está em que a aplicação simultânea dos diferentes critérios de classificação usados por Hart não irá gerar classes equivalentes de regras: ao analisar uma mesma regra sob os três critérios, nem sempre eles indicarão para o mesmo resultado. Assim, a associação feita por Hart entre, por um lado, o que ele denomina regras primárias e regras que (i) 
impõem deveres; (ii) envolvem mudanças físicas; e (iii) não se referem a outras regras, e, por outro lado, entre regras por ele ditas secundárias e regras que (i) conferem poderes; (ii) envolvem a criação ou alteração de deveres e obrigações; e (iii) se referem a outras regras não representa uma relação de equivalência.

Por um lado, nem todas as regras secundárias conferem poderes (Páramo Argüelles, 1984, p.231; MacCormick, 2008, p.134); por outro, regras primárias não se limitam a impor obrigações, e não é difícil encontrar exemplos - como as regras que disciplinam a celebração de contratos e testamentos - de regras ditas primárias que conferem poderes ${ }^{40}$. Por outro lado, é comum ver a regra de reconhecimento - a mais importante das regras secundárias - sendo caracterizada (em parte com razão, como será visto adiante) como uma regra que impõe obrigações (Shapiro, 2009, p.240; Perry, 2009, p. 296; Raz, 1979, p. 93 e 1999, p. 146; MacCormick, 2008, p. 132). Nas palavras de Hacker (1977, p.20):

Regras secundárias podem tanto ser sobre regras secundárias quanto sobre regras primárias, e elas não são mais sobre regras do que são sobre comportamentos, pois elas guiam comportamentos tanto quanto regras primárias o fazem. Ademais, regras primárias também podem ser - incluir referência a outras regras, por exemplo se os fatos relevantes para a performance dos atos que a regra guia envolvem a referência à existência ou escopo de outras regras, ou ao fato de violação ou adequação a outras regras. Consequentemente, invocar a distinção de regras que pressupõem a existência de outras regras, em oposição às que não o fazem, não será adequado.

Ainda, a relação de "parasitismo” entre regras pode ser entre duas regras que impõem obrigações (MacCormick, 2008, p.133) ou até mesmo a inversa da suposta por Hart: é possível conceber regras que impõem obrigações que sejam sobre ("parasitárias a”) regras que conferem poderes. Um exemplo são as regras que impõem deveres aos autoridades públicas no exercício de suas funções ${ }^{41}$, e até a própria regra de reconhecimento - uma regra secundária que para alguns autores é uma regra que impõe deveres aos officials, e que versa sobre - se relaciona com - a regra que confere poderes aos juízes para tanto, a regra de adjudicação. MacCormick (2008, p.133) oferece a seguinte elucidação:

${ }^{40}$ É irônico notar que o próprio Hart usa extensivamente tais exemplos de regras para criticar a teoria de Austin ([1961] 2009, p.35) mas parece ignora-las quando desenvolve a sua própria teoria.

${ }^{41}$ Uma possível refutação ao exemplo é a que indica que os “deveres” impostos a tais sujeitos na verdade decorrem dos próprios limites da outorga de poder que lhes é feita pela regra 
Isso sugere uma descrição de regras primárias que as caracterize como todos os requerimentos categóricos que governam atos naturais ${ }^{42}$ e outros atos que nem sempre ou não necessariamente invocam regras (em contraste, por exemplo, com requerimentos como os referentes ao modo correto de agir ao tomar decisões judiciais)... As regras secundárias, sob este ângulo, representam um conjunto variado. Certamente, todas as regras que conferem poderes individuadas como tal contarão como regras secundárias. Mas também irão regras ou outros standards que impõem deveres naqueles que exercem poderes, e assim regras que provêm remédios ou penalidades pela violação de regras primárias e por aí fora. Em geral, regras secundárias são uma classe internamente diversa de regras que se mantém em alguma interrelação sistêmica com outras regras ou standards de conduta compreendidos pela elucidação acima das regras primárias e standards de conduta.

Assim, talvez seja melhor - ou talvez até forçoso - considerar a distinção promovida por Hart entre regras primárias e secundárias como uma distinção por enumeração: secundárias são as regras de reconhecimento, adjudicação e alteração; regras primárias são todas as demais (Hacker, 1977, pp.20-21). Isso não prejudica em nada sua importância, nem o fato de que a união de regras primárias e secundárias é a “chave para a ciência da teoria do direito” (Hart, [1961] 2009, p. 106).

Apesar de parecerem facilmente diferenciáveis entre si, um olhar aprofundado mostra que, na verdade, cada uma das três regras secundárias parece pressupor ao menos uma das outras (MacCormick, 2008, p.140), o que também é fonte de críticas à concepção hartiana original, ainda que o próprio Hart tenha admitido a inevitável interrelação entre as três regras secundárias (Hart, [1961] 2009, pp.124-125).

Para Gardner (2011, pp.183), as regras secundárias se encontram em referência cruzada e, portanto, dependem umas nas outras para sua inteligibilidade, ainda que cada uma mantenha sua força normativa. Cada uma regula diferentes agentes e ações, ou até as mesmas ações dos mesmos agentes, mas de modos diferentes. Ruiz Manero (1990, p.113) destaca o caráter funcional do critério distintivo entre as regras secundárias, referindo-se ao remédio que cada uma aporta para os problemas indicados por Hart. Tal critério, entretanto, não parece ser completo, e ainda que a distinção entre as três funções a que

${ }^{42}$ Atos naturais (como o de matar ou agredir alguém) seriam aqueles que em si mesmos não são definidos como atos invocadores de regras ("atos jurísticos”). A diferença reside no ponto de tais atos: enquanto o ponto dos atos jurísticos é produzir consequências legais e não puramente físicas, os naturais se voltam para a produção de consequências físicas, mesmo que deles derivem consequências legais - como a punição pelo assassinato (MacCormick, 2008, p.131). 
correspondem as três classes de regras secundárias seja clara e permita uma compreensão geral da estrutura dos sistemas jurídicos, ela na prática resulta mais que problemática, pois as regras secundárias geralmente aparecem misturadas, integradas.

Quanto à relação entre a regra de reconhecimento e a de alteração, o próprio Hart ([1961] 2009, p.124) admitiu que as normas de reconhecimento devem "fazer referência à atividade legislativa como um traço identificado das normas”. Mas então seria alguma das duas regras supérflua? Em especial, seria a regra de reconhecimento supérflua, considerando a regra de alteração, pois para explicar os fenômenos jurídicos que ela regra de reconhecimento pretende explicar bastaria recorrer à regra de alteração, como pretende Jeremy Waldron (2009b); ou, sob outra perspectiva, se uma norma que tenha sido produzida de acordo com as regras de alteração constitui uma indicação indiscutível de que essa norma pertence ao sistema, não seria possível concluir que a regra de reconhecimento engloba também a todas as regras de alteração do sistema? Não seria mais vantajoso falar, como na tradição continental, em "normas sobre a produção jurídica” (Ruiz Manero, 1990, pp. 114-117)?

Parece haver bons motivos para discordar de Waldron: primeiro, ele parece partir de uma premissa que será posteriormente questionada ao afirmar que a regra de reconhecimento pressupõe que as demais regras secundárias (que constituem instituições de alteração e aplicação do direito) já estejam em prática quando de sua instituição (2009b, p. 328). Aceitar essa premissa parece ser consequência da adoção de outras premissas relativas à natureza do grupo reconhecedor, entendendo a regra como uma convenção coordenativa praticada apenas por autoridades públicas (2009b, p. 333). Em segundo lugar, Waldron (2009b, p. 343) resiste à diferenciação entre regras que conferem poderes e impõem deveres, afirmando que “a ideia de um poder é a ideia da capacidade de alterar os deveres de alguém”, de modo que a regra de reconhecimento seria supérflua caso considerássemos uma regra de modificação que permitisse ao Congresso legislar e, consequentemente, alterar os deveres dos demais atores no sistema jurídico. Entretanto, como afirma Gardner (2011, p. 177), isso não demonstra que a regra que confere poderes é também a regra que impõe deveres, mas tão somente mostra que a regra que confere poderes pressupõe a que impõe 
deveres, ou, no máximo, que uma regra pressupõe a outra. Mas, frise-se, isso não significa que uma regra seja idêntica à outra.

O argumento de Ruiz Manero também não prospera. É preciso considerar que quando o autor espanhol fala de regra de reconhecimento nas constituições, ele não está se referindo à regra última de reconhecimento, que, como visto anteriormente, reside em um nível anterior ao do texto constitucional. Ademais, há que se notar a diferença conceitual entre o dispositivo textual legal e a norma jurídica (Sgarbi, 2007, p. 84). Assim, os mesmos dispositivos jurídicoconstitucionais podem conter normas de alteração e normas de reconhecimento não últimas - algumas regras podem sim cumprir mais de uma função, mas, de qualquer modo, a regra em questão não poderá ser considerada uma regra última de reconhecimento, que não se refere a critérios de alteração, como será visto adiante. Além do que, as chamadas normas de "produção jurídica" - no caso brasileiro, como as normas contidas nas Leis de Introdução às Normas do Direito Brasileiro $^{43}$ - não são regras últimas de reconhecimento, mas normas de reconhecimento derivadas - quer incorporadas na legislação ordinária ou constitucional - e sua validade depende daquelas.

Quanto à relação entre normas de adjudicação e reconhecimento, Hart ([1961] 2009, p.126) ${ }^{44}$ reconhece que a norma de julgamento que conferir jurisdição, que estabelece o poder jurisdicional de conferir decisões autoritativas, será também em certa medida (imperfeita) uma norma de reconhecimento, pois dá aos tribunais o poder de "dizer o direito", de modo que os julgamentos se tornam “fonte" do direito.

Novamente, o argumento que pretende colapsar ambas regras secundárias não pode prevalecer. O principal motivo, como notam alguns autores, está no fato de que a regra de reconhecimento não é uma regra que meramente confere poderes, mas sim uma regra que impõe obrigações (Raz, 1970, pp.198-199; MacCormick, 2008, p.132; Gardner, 2011, p. 175), especificamente uma

${ }^{43}$ Decreto-Lei no 4.657, de 1942, com Redação dada pela Lei no ${ }^{\circ} 12.376$, de 2010.

${ }^{44}$ Na segunda edição inglesa lê-se: "Indeed, a system which has rules of adjudication is necessarily also committed to a rule ofrecognition of an elementary and imperfect sort. This is so because, if courts are empowered to make authoritative determinations of the fact that a rule has been broken, these cannot avoid being taken as authoritative determinations of what the rules are. So the rule which confers jurisdiction will also be a rule of recognition, identifying the primary rules through the judgments of the courts and these judgments will become a 'source' of law." (HART, H.LA. The Concept of Law. Oxford: Clarendon Press, $2^{a}$ edição, 1994, p. 97). 
obrigação legal no grupo reconhecedor relevante (os officials, segundo tais autores). Nas palavras de Gardner (2011, pp.175-176):

[uma das regras de reconhecimento no Reino Unido] é a regra pela qual o que a Rainha no Parlamento decreta é direito. Essa regra dá aos agentes aplicadores do direito o dever legal de aplicar quaisquer regras que o Palramento decrete. Mas ela impõe esse dever no próprio Parlamento? Não. (...)

Do mesmo modo que o Exército é identificado pela Carta de Direitos de 1689 mas não é regulado por ela, também o Parlamento é identificado por esta famosa regra de reconhecimento mas não é regulado por ela. Ele é regulado ao invés por uma correspondente regra de alteração que confere nele os poderes legais para promulgar leis, e no processo impondo, pela regra de reconhecimento, um dever legal nos agentes aplicadores do direito de aplicar as regras contidas nesta legislação promulgada

Entretanto, o ponto de crítica mais incisiva reside em um aparente problema de circularidade envolvendo as regras secundárias em questão: a regra (última) de reconhecimento - na concepção que toma em conta apenas os officials - em especial os juízes - como grupo reconhecedor relevante - depende exclusivamente da prática dos tribunais, que por sua vez são identificados por normas de adjudicação. Estas, em seu turno, devem ser reconhecidas pela regra última de reconhecimento que, segundo a abordagem tradicional, depende dos tribunais criados pelas normas de adjudicação (Ruiz Manero, 1990, p. 114). Este problema retornará com mais detalhes no tópico seguinte, e uma solução que se pensa satisfatória será oferecida para evitar a circularidade.

\subsection{1}

\section{O problema da circularidade}

Para identificar normas jurídicas, é necessário olhar para a regra de reconhecimento. Esta é a regra última de todo sistema jurídico, da qual a validade de todas as demais regras (inclusive as regras secundárias de adjudicação e alteração) depende - caso contrário, não seria uma regra propriamente última, por óbvio. O problema é que na concepção canônica a regra de reconhecimento pressupõe a figura dos juízes, que, por sua vez, pressupõe uma regra de adjudicação que os institua como juízes. Regras de adjudicação não são últimas, e sua validade está condicionada pela regra de reconhecimento. Mas a própria regra de reconhecimento parece pressupor a regra de adjudicação. 
Mais detalhadamente: de acordo com Hart, a existência da regra de reconhecimento tem como condição necessária e suficiente que os juízes (e officials) usem como "padrão público e comum para a decisão judicial correta” (Hart [1961] 2009, p. 149) os mesmos critérios últimos de validade jurídica. Isso implica que para poder determinar o conteúdo da regra de reconhecimento de um sistema jurídico é preciso determinar previamente quem são os juízes e tribunais desse sistemas. Entretanto, para identificar os juízes é necessário identificar as normas jurídicas (regras de adjudicação) que fixam as condições pelas quais certos indivíduos são juízes; afinal, foi o próprio Hart que enfatizou que somente é possível identificar indivíduos qua juízes ou officials baseando-se em regras que confiram os poderes relevantes a tais sujeitos (MacCormick, 2008, p.136; Marmor, 2011, p. 56). Em consequência, para identificar as normas jurídicas é preciso primeiro identificar as normas jurídicas. (Arena, 2014, p. 35). Isto parece ser um paradoxo, um “exemplo perfeito de círculo vicioso” (Ruiz Manero, 1990, p. 13). Os juízes determinariam os critérios últimos para comprovar a validade das próprias normas que lhes conferem jurisdição como juízes (Páramo Argüelles, 1984, p. 257).

Se a autoridade legal somente pode ser criada por regras, quem faz as regras que criam autoridade (Shapiro, 2001, p.152)? Em virtude de que um sujeito atua como juiz? A resposta somente pode ser (ao menos para a esmagadora maioria dos casos de sistemas jurídicos modernos) que existem regras jurídicas (constitucionais) que dispõem sobre o exercício da função jurisdicional e do acesso aos cargos decisórios - o que adiciona mais uma "volta” ao círculo: a regra de reconhecimento parece depender das regras de adjudicação, que dependem de regras de alteração (MacCormick, 2008, p.139), que por sua vez dependem da regra de reconhecimento. Em suma, um cenário caótico em que as metarregras parecem depender umas das outras (Lagerspetz, 1995, p. 158).

Como lidar com este círculo vicioso? Raz (1995, p. 295) considera a circularidade inócua e Lagerspetz (1995, p. 160) a chama de inofensiva, posto que a teoria em si não é circular; seria, pois a teoria de um fenômeno reflexivo ou circular, mas isso não causaria maiores problemas. Não agrada essa resposta, já que a circularidade está enraizada nas fundações do sistema jurídico hartiano. Cabe, pois, enfrentá-la. Para tanto, é possível adotar algumas vias: (1) mostrar que o critério de identificação dos juízes não é uma norma jurídica - (1a) que não é 
uma norma ou (1b) que não é jurídica - (2) que os indivíduos na prática não são juízes; (3) que as regras que constituem as práticas também constituem os papéis dos atores que a praticam.

Seguem (1a) Nino e Raz, para quem os juízes se identificam mediante critérios fáticos, não normativos; ou seja, por meio de coerção. Raz (1980, pp. 193-194) identifica os órgãos primários sobre a base da coerção - é juiz quem consegue impor a coerção (Arena, 2014, p.35), quem executa ou de que cuja decisão depende a execução de sanções (Raz, 1980, p. 194). Nino (2003, p.128), por sua vez, os caracteriza como aqueles cujas decisões relativas ao uso da coação estatal em casos particulares são habitualmente obedecidas, quem de fato pode (no sentido fático e não normativo) determinar o exercício do monopólio coercitivo estatal em casos particulares, ou seja, quem esteja em posição de fazer mover o aparato coerticivo do Estado.

Essa proposta padece, segundo Manero, dos mesmos problemas da caracterização do 'legislador’ em termos de obediência habitual que propuseram Bentham e Austin. (Ruiz Manero, 1990, p. 15). Essa interpretação de Hart faria com que ele adotasse justamente a postura que critica e a sujeita aos mesmos problemas (Ruiz Manero, 1990, p.130-131) ao fundamentalmente colocar a coerção na base do sistema jurídico, porém agora na identificação do grupo reconhecedor relevante. É necessário, portanto, falar de regras (Ruiz Manero, 1990, p. 131). De modo similar, falar em aparato estatal, em monopólio da força por meio do Estado, implica em falar em um sistema jurídico; e falar em sistema jurídico depende, obviamente, de uma regra de reconhecimento. Há ainda um problema de sobreinclusão, visto que há indivíduos que possuem capacidade coercitiva mas não são juízes. Para evitar a sobreinclusão, fazendo qualificações ao conceito de coerção como faz Nino ao conceituá-la como monopólio coercitivo estatal, o critério deixaria de ser meramente fático (pois, novamente, para definir o que é estatal é necessário uma regra) e a circularidade retornaria (Arena, 2014, p.35).

A solução (1b) é advogada por MacCormick (2008, pp. 142-151). Para ele, o problema se resolve se para a identificação dos juízes não é necessário que existam normas jurídicas que identifiquem certos indivíduos como juízes, bastando que de algum modo exista uma norma que imponha deveres nestes sujeitos. Esta pode ser uma mera norma social que não pertença ao direito e que 
imponha a certos indivíduos o dever de identificar certas normas como direito. A proposta de MacCormick consiste essencialmente em prescindir das powerconferring rules na hora de caracterizar o conceito de 'juiz' e de construir essa caracterização exclusivamente sobre a base das regras sociais de dever. MacCormick tenta retomar o experimento de pensamento proposto por Hart, com algumas adaptações, para mostrar a possibilidade e o modo pelo qual há a evolução do sistema jurídico primitivo em um sistema completo, com o desenvolvimento das regras secundárias, necessariamente interrelacionadas. MacCormick mostra como anciãos da sociedade primitiva, por uma regra costumeira, têm o dever de solucionar os conflitos entre os particulares, e como desta atividade de por fim aos conflitos se desenvolvem as regras secundárias e, consequentemente, amadurece o respectivo sistema jurídico. Apesar de conceitualmente possível - e até de ser uma plausível tese para explicar a evolução do direito inglês (MacCormick, 2008, pp.150-51) - a explicação não é satisfatória.

Os problemas dessa solução são conceituais e metodológicos. Em um aspecto conceitual, a identificação dos juízes parece depender de normas jurídicas, posto que o status normativo de juiz exige fazer referência a competências, que precisam vir de uma regra (Arena, 2014, p.36), sendo portanto necessário sobretudo que o sujeito identificado como tal "seja titular da potestade ou poder normativo de ditar determinações aplicativas de caráter obrigatório” (Ruiz Manero, 1990, p. 14). Sob um aspecto metodológico, a solução é descritivamente insatisfatória e possui um baixo poder explicativo da realidade, pois na maioria dos ordenamentos existem regras jurídicas, não morais ou meramente sociais, que definem o status e a competência dos juízes. Ademais - e de modo mais relevante - a solução não atende ao constraint hermenêutico ${ }^{45}$, visto que não dá conta de como os próprios agentes identificados como juízes se vêem na prática jurisdicional. Ela não descreve com adequação a relação dos juízes com o direito do modo como os agentes no mundo real de fato o fazem (ao menos não na esmagadora maioria dos ordenamentos jurídicos modernos), não apreende o modo como eles juízes entendem seu papel no ordenamento jurídico. Isso porque os

\footnotetext{
${ }^{45}$ Nas palavras de Hacker (1977, p. 9): Um dos temas salientes em hermenêutica é que a descrição de fenômenos distintivamente humanos envolve entender a situação descrita como ela é apreendida pelo agente cujo comportamento está sendo explicado e entendido. Deve-se fazer referência ao quadro conceitual (conceptual framework) do agente.
} 
juízes reconhecem que atuam com a competência e nos limites impostos pelas Constituições (sejam elas escritas ou não) ou qualquer que seja law of the land. A descrição de MacCormick não é apurada de acordo com o ponto de vista interno dos officials em relação à sua própria atividade jurisdicional na esmagadora maioria dos sistemas jurídicos modernos.

A tese (2), por sua vez, afirma que os envolvidos na prática não são juízes, ou pelo menos que não são juízes no memomento da prática fundacional do sistema jurídica. Haveria uma cisão lógico-temporal na atividade de reconhecimento que permitiria identificar certos sujeitos anteriormente à sua condição de juízes. Coleman (2001, p. 381) apresenta a distinção entre dois papéis dos indivíduos de cuja prática depende a existência da regra de reconhecimento: primeiro, como indivíduos que escolhem guiar seu comportamento por uma certa regra; em segundo lugar, como indivíduos cujo comportamento se encontra guiado pela regra de reconhecimento. É no primeiro papel que os indivíduos dão ou podem dar lugar à regra de reconhecimento. Uma vez que esta regra exista, tão logo podem os indivíduos desempenharem o segundo papel, em que são funcionários que guiam seu comportamento segundo essa regra. Isso parece estar de acordo com o dito por Hart ([1961] 2009, pp.197-199), ao afirmar que há casos em que a autoridade dos tribunais para decidir certas questões só seja reconhecida ex post facto; ou seja, em retrospectiva será dito que eles sempre tiveram tal autoridade, quando na verdade o tribunal a adquiriu no momento em que decidiu tal matéria fundamental.

Shapiro (2001, p.156) apresenta versão similar, afirmando que cortes não são formadas quando alguma regra as identifica como única fonte de identificação do direito; ao contrário, certos grupos são cortes em um sistema jurídico porque elas geram e sustentam a regra de reconhecimento. Seria uma afirmação falsa a de que cortes possuem autoridade em virtude de serem cortes dos respectivos sistemas legais. Uma vez determinado que certos grupos criaram e sustentaram a regra de reconhecimento, seria possível afirmar que esses grupos são cortes daquele sistema jurídico.

As respostas de Coleman e Shapiro também não são satisfatórias. Em primeiro lugar, por também falharem no teste hermenêutico ao desconsiderarem a percepção dos juízes de que são juízes em virtude de regras, mas não anteriormente a elas; de que seu comportamento faz a regra de reconhecimento 
possível, mas é a regra que faz o ordenamento jurídico possível e é o ordenamento jurídico que os faz juízes (Arena, 2014, p.38). Além disso, trata-se de soluções arbitrárias no sentido de que partem da premissa que os juízes formam de modo exclusivo o grupo reconhecedor relevante - premissa que se quer atacar aqui. Sob esse aspecto, a argumentação de Shapiro tem a forma de uma petição de princípio, pois tenta provar uma conclusão assumindo como premissa o que se quer provar. Shapiro identifica o grupo que cria e sustenta a regra de reconhecimento como sendo “corte”. Mas e se o próprio status daquele grupo enquanto corte dependesse de seu reconhecimento enquanto tal por algum outro grupo - seja ele os demais officials ou a população como um todo? O argumento de Shapiro ficaria enfraquecido nesse caso, e é justamente isso que parece afirmar Hart ao falar em “prestígio adquirido” - prestígio junto a quem? Não faria sentido que o prestígio seja dentro do próprio grupo de juízes, mas a frase abaixo só é inteligível caso se considere que a referência é a algum outro grupo reconhecedor ([1961] 2009, p. 199):

(...) e o que torna possível esses notáveis desenvolvimentos das normas mais fundamentais por parte dos tribunais é, em grande parte, o prestígio adquirido por estes como resultado de sua atuação inquestionavelmente pautada por normas quando exercem sua autoridade jurisdicional sobre as vastas áreas centrais do direito

Marmor (2010, pp.55-56) e Arena (2014, p. 38 parecem adotar a tese (3). Marmor compara as regras jurídicas às regras de um jogo, pelo seu caráter constitutivo. As regras do xadrez são regras dos jogadores de xadrez, daqueles que se engajam na prática, e o papel de “jogador de xadrez” é constituído pelas regras que constituem o próprio jogo de xadrez. "Quando há um conjunto de regras que constitui um certo tipo de atividade - como jogar xadrez ou atuar numa peça de teatro - as regras constituem tanto o tipo de atividade em questão e o papel que os sujeitos ocupam na atividade” (Marmor, 2011, p. 56). Do mesmo modo, no direito, as regras seguidas pelos juízes que ocupam um papel institucional poderiam ser as mesmas regras que constituem o papel institucional que forma parte da atividade constituída pelas regras.

Novamente, a solução oferecida não parece adequada. Marmor fala em “um conjunto de regras” ( $a$ set of rules) constitutivas. De duas, uma: ou ele está se referindo a uma regra constitutiva somada a outras regras não constitutivas, ou ele se refere a um conjunto de regras constitutivas. A primeira hipótese faria inócua a 
distinção feita por Hart entre as três regras secundárias. Se apenas uma regra constitutiva exerce toda a função de constituir e regular as atividades de poder inerente (jurisdicionais, legislativas e executivas) não faria sentido falar em três regras, mas em uma regra com três funções. Como visto anteriormente, a regra de reconhecimento se diferencia das demais regras secundárias, motivo pelo qual esta linha de argumentação não pode ser adotada. A segunda interpretação esvazia o argumento de Marmor ao não resolver em nada o problema da circularidade, pois aqui também seria necessário distinguir entre as regras constitutivas. Ademais, Marmor parece negar um aspecto fundamental à teoria hartiana, ao afirmar que a confusão a respeito da circularidade ocorre em virtude de Hart ter incorretamente assumido que regras constitutivas são metarregras e que regras de reconhecimento são metarregras (Marmor, 2011, p. 56 nota 26). Entretanto, por mais que a regra de reconhecimento possa ter um caráter de imposição de deveres, ela não deixa - e não poderia deixar - de ser uma regra a respeito de regras, pois sua principal função é justamente conferir status jurídico às demais normas. Por fim, como a solução (2), neste caso também não se explica o motivo de olhar para o comportamento de um determinado grupo indivíduos e não de outros ou de todos, partindo-se da premissa de que são os juízes o grupo reconhecedor relevante. Se há grupos diferentes de indivíduos com práticas diversas e competitivas, para quem olhar? Se é uma questão de quem se sagra obedecido, vitorioso, então é uma questão fática, não normativa, o que aponta para a primeira solução, rechaçada anteriormente.

Em resumo: a regra de reconhecimento última é identificada pela prática dos juízes. Entretanto, para a identificação dos juízes é necessário que exista uma regra (secundária, de adjudicação) que crie o cargo de juízes, defina suas competências, confira seus poderes e apresente os critérios pelos quais os indivíduos podem se tornar juízes. Mas se é necessária tal regra, a regra de reconhecimento consubstanciada na prática dos juízes não é mais propriamente última e portanto não pode ser o fundamento de validade do sistema. As respostas apresentadas pela doutrina não são plenamente satisfatórias, e uma solução mais adequada, como será visto adiante, envolve considerar o povo no grupo reconhecedor relevante, partindo da existência do povo como fato, como dado sociológico, verificável independentemente de uma regra social ou jurídica. 
3.2 A normatividade da regra de reconhecimento

A necessidade de uma compreensão teórico-analítica do direito que dê conta do seu caráter obrigatório, vinculativo, apesar de não unânime na tradição positivista $^{46}$ (Schauer, 1998, pp.71-78; Himma, 2001; Bix, 2006, p.7) é constatada por diversos autores (Raz; 1999, Coleman e Leiter, 2010, pp.228-229; Coleman, 2001, p. 357; Green, 2004, p. 515; Arena, 2014, p. 46), que tentam adscrever sentido normativo à prática social convergente, ao comportamento convergente dos agentes relevantes, localizando o sentido normativo na próprio fato da convergência (Schauer, 1998, p.72).

Mas do que exatamente se fala quando se fala no 'caráter normativo' do direito? Na filosofia jurídica, os termos normatividade e autoridade muitas vezes parecem fazer referência ao mesmo fenômeno ou característica do direito (Coleman, 1991, p. 705; Schauer, 1998, p. 71; Bix, 2006, p. 6; Arena, 2014, p.210), qual seja, a de pretender governar ações daqueles que se sujeitam a seu âmbito de incidência (Raz, 1999, pp. 15ss), a sua vinculatividade (bindingness) (Schauer, 1998, p.71). Entretanto, parece ser possível perceber uma diferença na forma como os termos são usados na tradição hartiana que justifique ao menos afirmar que se tratam de termos referentes a questões intrinsecamente relacionadas, porém diferentes ${ }^{47}$.

Em resumo, o termo normatividade parece, num certo sentido, referir-se ao dever legal, ou seja, ao 'dever 'ou 'obrigação' de seguir o direito, à vinculatividade do direito, e está atrelada à questão de como o direito gera essas obrigações. Este, aliás, é um dos vieses da crítica de Hart a Austin, cuja teoria imperativa não possuía os recursos para fazer distinções centrais a esta linguagem

${ }^{46}$ A questão seria saber se a normatividade é um componente essencial do direito, em todos os mundos possíveis. Schauer argumenta que o direito clama ter normatividade, mas que isso não significa que ele de fato tem. Ele não se compromete com a tese de que não tem, mas marca o ponto de que há boas razoes morais para não resolver a questão da normatividade do direito em um nível definicional ou conceitual (Schauer, 1998, pp. 77 e 78). A normatividade do direito não seria requerida pelo conceito do direito (Schauer, 1998, pp.76-78).

47 Não é do escopo do presente trabalho uma detalhada análise dos conceitos de normatividade e autoridade, adentrando, por exemplo, nas teses Razianas justificatórias de autoridade (Joseph Raz."Authority, Law, and Morality” in Ethics in the Public Domain. Oxford:Clarendon Press, 1994). 
normativa do direito, como, paradigmaticamente, a distinção entre ter uma obrigação e ser obrigado (Coleman, 2001, p. 90; Hart, [1961] 2009, p.114).

A concepção de autoridade, por sua vez, está atrelada à ideia de razões, em especial de razões excludentes para ação, ou seja, que a fonte de autoridade requeira submissão mesmo quando o sujeito sob autoridade discorde da razão oferecida (Raz, 1979, p. 3; Green, 1999, p. 44). Para um positivista, a ideia de autoridade está intrinsecamente ligada ao conceito de regras ${ }^{48}$ (Raz, 1999, p. 49; Coleman, 2001, p.384, nota 22), que são o meio pelo qual o direto instrumentaliza essas razões de segunda ordem (Raz, 1999, pp 35-48).

Regras são razões para ação (Raz, 1999, p. 51) no sentido em que agentes as tomam como tal, exercendo pressão para conformidade pelo fato de serem regras, não pela valoração de seu conteúdo (Schauer, 1991, p. 4). Assim, é possível distinguir entre comportamentos governados e comportamentos guiados por regras: estes são os que a norma é a razão pela qual o agente age, enquanto aqueles são comportamentos meramente sujeitos à norma; a maioria das normas pretende governar comportamentos, sejam eles praticados de fato ou não (Coleman, 2001, p. 359). Mas a possibilidade de uma regra jurídica governar comportamentos depende no positivismo hartiano da existência conceitual ou analiticamente anterior de uma prática social entre os agentes relevantes, ou melhor, de uma regra social que, fundada em uma convergência e uma atitude crítico-reflexiva, guie o comportamento de tais agentes.

Em um ordenamento jurídico, portanto, as regras - que criam obrigações jurídicas - são elas mesmas criadas pelo fato de que os agentes do grupo reconhecedor relevante são guiados por uma regra que trata essas normas como autoritativas. Nas palavras de Shapiro (Shapiro, 2001, p.154), a constituição possui a autoridade que ela clama porque certos membros da sociedade são guiados por uma regra de reconhecimento que impõe a obrigação de levar a constituição a sério; a regra de reconhecimento, por sua vez, existe e é autoritativa

\footnotetext{
${ }^{48}$ Raz prefere o termo 'normas' em referencia às normas mandatórias, encompassando tanto regras quanto princípios (1999, p.49). Não é do escopo do presente trabalho adentrar na distinção entre os dois tipos normativos, nem no debate a respeito da inclusão da categoria dos princípios dentro do positivismo hartiano (Hart, [1961] 2009, pp.319ss). Ao se falar em 'regras' aqui se faz referência, portanto, às regras mandatórias (prescritivas), a não ser quando expressamente indicado em contrário; afinal, nem todas as regras são prescritivas ou conferem razões para agir (Schauer, 1991, p.3, nota 3).
} 
meramente por ser aceita, ou seja, ela governa comportamentos na sociedade em geral em virtude de ela mesma guiar comportamentos do grupo reconhecedor de um determinado modo relevante. O tema será retomado oportunamente.

\subsection{1}

Regras que conferem poderes, regras que impõem deveres e regras constitutivas

Uma das principais críticas de Hart a Austin envolve a constatação da incapacidade de sua teoria do comando em dar conta da "diversidade das normas jurídicas”, representando-o apenas com regras que, baseadas na ameaça de sanções, impõem deveres e obrigações. Como Hart ([1961] 2009, p.35) demonstra, nem todas as normas impõem deveres e obrigações, entre as quais as normas sobre como fazer um testamento ou um contrato. Os sujeitos possuem o poder, ao praticar o ato nas condições especificadas, de efetuar uma alteração normativa (MacCormick, 2008, p.135); como existem normas que conferem poderes, também há poderes para criar e regular a aplicação dessas normas, e normas conferindo poderes para tanto (Raz, 1999, p.106). O não cumprimento de tais regras não seria propriamente uma infração ou transgressão, mas apenas a nulidade dos atos praticados com base nos poderes legalmente adquiridos. Hart, refutando Austin e Kelsen, demonstra que a nulidade - a não produção de efeitos jurídicos - cominada à violação das normas que conferem poderes não pode ser confundida com uma sanção ([1961] 2009, pp.44ss). Como afirma o autor, entender a nulidade como sanção é análogo a pensar que, nas regras de um jogo, são proibidas todas as jogadas exceto as que pontuam (Hart, [1961] 2009, p.46).

Regras que impõem deveres e obrigações guiam especificamente a conduta do agente derrotando as suas demais razões para agir. E como as regras que conferem poderes funcionam na razão prática de seus destinatários? Segundo Raz (1999, p. 106), guiam o comportamento (sua decisão de exercer ou não o poder/faculdade) de modo indeterminado, não sendo elas mesmas razões completas para ação, mas dependendo de razões outras: se o agente tem razões para obter o resultado que o poder lhe permite lograr (razões para definir antecipadamente a repartição de seus bens entre seus herdeiros em um testamento, por exemplo), ele o fará; se não tiver, não fará (Raz, 1980, p. 227). 
Mais importante para o presente estudo que as normas relativas a poderes privados são as normas que conferem poderes públicos, como as normas que conferem e delimitam poderes jurídicos a autoridades públicas (Hart, [1961] 2009, p.38). Como afirma MacCormick (2008, p.134), para Hart o importante não é tanto que que algumas regras conferem poderes, mas o tipo de poderes que certas regras conferem. Entre elas, estão algumas das mais importantes regras nos ordenamentos jurídicos modernos (quer possuam constituições escritas ou não), como as regras que conferem poderes legislativos (regras de alteração) e jurisdicionais (regras de adjudicação). Em verdade, as regras que conferem poderes são essenciais ao ordenamento jurídico na teoria hartiana. Este é um conjunto relacionado de normas e poderes, de normas que dão vida a poderes e de poderes que produzem normas. Mais: há, por um lado, um conjunto de normas que criam outras normas mediante poderes e, por outro, um conjunto de poderes que dão vida a novos poderes mediante normas (Páramo Argüelles, 1984, p.229). Segundo Shapiro (2009, p.235), em contraste com Bentham and Austin - que insistiam na afirmação de que é o poder soberano que faz as normas - para Hart são as normas que fazem o soberano.

Contudo, a noção de regra que confere poderes não deve ser confundida com as chamadas regras constitutivas (Searle, 1970) ${ }^{49}$. Regras constitutivas criam, definem e constituem fatos institucionais que não existiriam sem elas, que podem ser reduzidas a uma forma “X conta como Y no contexto C” (Searle, 1970, p. 35; Raz, 1999, p.108). Tais regras desempenham um papel muito importante na construção do mundo, pois uma boa parte da realidade em que vivemos consiste em fatos instuitucionais: entidades sociais existem por conta da contínua aceitação de regras constitutivas. Ao contrário de fatos brutos (como pedras e árvores), que existem independentemente do que os homens pensam delas, fatos institutcionais existem apenas em função de suas regras constitutivas (Barber, 2010, p. 69), como ocorre com dinheiro e com o próprio direito (Lagerspetz, 1999, p. 232). Regras de jogos também são bons exemplos de regras constitutivas, pois a

\footnotetext{
${ }^{49}$ Não é do escopo do presente trabalho apresentar uma defesa das formulações de Searle - especialmente no que diz respeito à autonomia das regras constitutivas em relação às regulativas - das críticas de outros filósofos (Raz, 1999, pp. 109-111), mas tão somente apresentar uma visão geral que permita a análise da regra de recohecimento, segundo uma certa visão, como uma regra constitutiva.
} 
possibilidade de marcar um gol não advém de uma regra criando uma obrigação ou conferindo um poder para tanto, mas sim das regras que constituem o jogo de futebol (Schauer, 1991, p. 6). No entanto, é possível perceber que muitas regras constitutivas têm seu lado regulativo, possuindo, portanto, um duplo aspecto, primeiro definindo o processo e depois regulando-o (Lagerspetz, 1995, p.18; Raz, 1999, p. 109; Schauer, 1991, p.7; Barber, 2010, p. 68). Isto é assim pois a regra que impede que gols sejam marcados utilizando-se as mãos não apenas controla o processo de marcar gols, impondo deveres nos jogadores, mas verdadeiramente constituem os processos; por sua vez, regras constitutivas que criam instituições como o caso das legislaturas e cortes - possuem um aspecto regulativo que confere poderes aos sujeitos que ocupam tais posições criadas. Isto não significa, entretanto, que o conceito de regras constitutivas seja supérfluo ou desnecessário; ainda que se diga que geralmente regras constitutivas possuem um aspecto regulativo, nem todas as regras regulativas possuem um aspecto constitutivo. Sem o aspecto constitutivo, as ações e coisas inseridas nos fatos institucionais não teriam sentido: por exemplo, é possível deslizar no chão e acertar uma pessoa com as pernas sem fazer referência às regras do futebol. “Dar um carrinho”, entretanto, é algo diferente, sendo constituído por algumas de tais regras, e a regra (ou o aspecto regulativo) que proíbe a entrada de “carrinho” opera, dentro do sistema das regras do futebol, do mesmo modo como a regra que proíbe matar alguém opera em um ambiente não constituído por regras (Schauer, 1991, p.7).

Esta breve análise nos permite chegar à muito debatida questão a respeito da normatividade da regra de reconhecimento e sua caracterização em um dos tipos de regras. Hart não chega a afirmar, n’O Conceito de Drireito, qual tipo de regra é a regra de reconhecimento - uma regra que impõe deveres ou uma que conferer poderes (Shapiro 2009, p.235; MacCormick, 2008, p. 132). Hart igualmente não chega a tratar expressamente (apesar de parecer implicar) as regras secundárias coletivamente como regras que conferem poderes, a despeito de parecer incluir, como notado, este aspecto deôntico como critério na sua confusa classificação entre regras primárias e secundárias. 


\subsection{2}

O papel da regra de reconhecimento na normatividade do direito

Como indicado, os conceitos de normatividade e autoridade estão intrinsecamente ligados; afinal, Hart pretende explicar a idéia de normatividade do direito em termos de obrigação, e isso só pode ser feito recorrendo à noção de regras, que são a forma pelo qual o direito instrumentaliza as razões peremptórias de segunda ordem. Só as regras possuem uma dimensão interna e geram obrigações (Struchiner, 2005, p.63).

A regra de reconhecimento se insere nesses debates como o ponto inicial a partir do qual se deve perquirir a respeito da normatividade e autoridade do direito. Aqui serão investigadas duas questões, muitas vezes tratadas de uma forma conjunta, mas que merecem ser reconhecidas em suas diferenças (Schauer, 1998, p.71): (i) como a regra de reconhecimento confere normatividade ao direito por ela identificado; e (ii) o que explica a normatividade da própria regra de reconhecimento.

Segundo Raz (1999, p.170), há duas formas de explicação para o uso de linguagem normativa no direito, sejam elas baseadas em crenças (belief-based) ou na validade dos enunciados jurídicos (validity-based). Com relação às normas primárias e até secundárias que são identificadas de acordo com os critérios especificados pela regra de reconhecimento, é possível afirmar que sua autoridade é baseada na sua validade, ou seja, decorre do pertencimento e validade perante o ordenamento segundo os critérios da regra de reconhecimento (Coleman, 1991, pp.707ss; Dickson, 2007, p.5). A regra de reconhecimento funciona, portanto, como fonte de autoridade para o resto do ordenamento (Hart, [1961] 2009, p.123). Mas como ela operacionaliza esta normatividade, se ela parece funcionar, na concepção original, mais como um teste, oferendo critérios de validade? Mais, como explicar a afirmação de Hart ([1961] 2009, p.126) de que, em certas circunstâncias, a norma de adjudicação, que conferir jurisdição, será também em certa medida (imperfeita) uma norma de reconhecimento, pois dá aos tribunais o poder de “dizer o direito", de modo que os julgamentos se tornam "fonte” do direito? Estaria Hart implicando que a regra de reconhecimento seria uma regra que confere poderes? Se sim, como ao conferir poderes ela explica a obrigação de seguir o direito por meio dela reconhecido? 
Parece não ser esta a interpretação correta, o que foi posteriormente confirmado por Hart (Raz, 1980, p. 198). Para alguns autores na tradição hartiana, a normatividade decorre do fato de que a regra de reconhecimento é uma norma que - ao menos em parte (Wacks, 2005, p. 77), ou primariamente (Coleman, 2001, p.384, nota 19) - impõe deveres nos agentes relevantes (os officials, em especial juízes) para que identifiquem e apliquem como direito apenas as normas que passam no teste de validade proposto pela regra de reconhecimento (Coleman, 2001, pp.357 e 368; Dickson, 2007, p. 6; MacCormick, 2008, p.132; Shapiro, 2009, p.240; Lamond, 2013, p. 115). “O padrão comum reconhecido pelos juízes é claramente uma regra que impõe deveres. Eles devem agir em acordo com o direito válido no exercício de seus poderes de decidir casos.” (MacCormick, 2008, p.132). Note-se que o poder mencionado por MacCormick advém da regra secundária de adjudicação, não da própria regra de reconhecimento. Gardner (2011, pp. 179-181) apresenta a seguinte explicação:

Na constituição - onde achamos as regras últimas de adjudicação e alteração elas conferem poderes inerentes para aplicar e alterar o direito. Mas se as regras de reconhecimento últimas de um sistema jurídico já concedem esses poderes para as mesmas instituições, por que seriam necessárias regras de adjudicação e alteração? Não seriam elas apenas duplicatas? A resposta é que elas são necessárias pois a regra de reconhecimento não confere esses ou quaisquer outros poderes legais. A regra de reconhecimento é uma regra que impõe deveres. Ela impõe um dever legal em autoridades públicas que aplicam o direito. Uma das regras de reconhecimento do Reino Unido - o clássico exemplo de Hart para regra de reconhecimento - é a regra pela qual o que a Rainha no Parlamento decreta é direito. Essa regra impõe nas autoridades públicas aplicadores do direito o dever legal de aplicar quaiquer regras que o Parlamento aprovar. Mas ela impõe esse dever no próprio Parlamento? Não. (...) Do mesmo modo como o exército é identificado pelo Bill of Rights de 1689 mas não é regulado por ele, também o Parlamento é identificado pela famosa regra de reconhecimento mas não é regulado por ela. Ele é regulado, entretanto, pela correspondente regra de alteração que a ele confere poderes legais para passar leis, e no processo impondo, pela regra de reconhecimento, um dever legal nas autoridades públicas aplicadores do direito de aplicar as regras contidas nessas leis. Assim, o argumento de Hart de que regras últimas de reconhecimento só podem ser regras customeiras não implica que apenas regras customeiras regulam instituições de poder inerente. Isso deixa aberta a possibilidade de que em alguns sistemas jurídicos as regras constitucionais de adjudicação e alteração - as regras que conferem às instituições de poder inerente o seu poder - sejam regras não customeiras.

Entender a regra de reconhecimento exclusivamente como uma regra que impõe deveres - e não como um mero teste de validade - parece resolver a questão da normatividade do direito por ela reconhecido, ainda que esta não seja a única saída possível. Perceber a regra apenas como um teste de validade - como 
um manual ou guia para saber quais regras pertencem ao respectivo ordenamento - além de colapsar entidades que possuem naturezas distintas (uma regra é normativa, enquanto um critério é meramente descritivo) (Himma, 2009, p. 98), é reduzí-la a sua função epistemológica, desconsiderando os seus outros caracteres, principalmente no que diz respeito à aceitação da regra de reconhecimento como padrão público comum de comportamento das autoridades públicas, o que sugere o próprio caráter normativo da regra (Lamond, 2013, pp. 114-115).

Mas em que se baseia a autoridade da própria regra de reconhecimento? Como visto anteriormente, não é possível falar na validade ou invalidade da regra de reconhecimento, sendo ela mesma o fundamento de validade de qualquer ordenamento jurídico. Assim, parece não ser possível tratar a normatividade da regra de reconhecimento em termos jurídicos internos ao sistema, muito menos em razão de aspectos morais, o que leva à conclusão que a sua normatividade é uma questão de fatos sociais (Coleman, 1991, p. 718); afinal, como visto, a regra de reconhecimento é uma regra social, e, como tal, composta por dois elementos: (i) uma regularidade de comportamento convergente somada à (ii) atitude críticoreflexiva característica do ponto de vista interno (Hart, [1961] 2009, p.76; Coleman, 2001, p.366). Qual dos dois elementos faz o trabalho normativo, qual deles explica sua força normativa?

Por um lado, Leiter e Coleman (em posição posteriormente revisada) parecem (pareciam) atribuir à convergência a normatividade da regra de reconhecimento, apesar de reconhecer que a aceitação, além de condição necessária para que uma prática social se transforme em uma regra, é um indicador de que tal prática é normativa (Coleman e Leiter, 2010, p. 235). Ao contrário dos que rejeitaram precocemente a possibilidade de que práticas sociais provejam a base para normatividade, Coleman coloca (em sua postura inicial) toda a força normativa da regra de reconhecimento na convergência - como se o próprio fato de que práticas habituais compartilhadas por certos membros em um grupo pudesse prover razões suficientes para ações destes e de outros no grupo; em especial, como se o fato da convergência entre os agentes relevantes (os juízes, para Coleman) provesse uma explicação de como certas práticas sociais o direito em especial - podem ser, assim, autoritativas (Schauer, 1998, p.72). 
Mas parece ${ }^{50}$ ser o outro elemento - a aceitação da regra de reconhecimento pelo grupo reconhecedor relevante - que explica a sua normatividade (Coleman, 2001, p.369). Ela seria capaz de regular a conduta dos agentes que a adotam no ponto de vista interno (pelo próprio fato de assim o fazerem) e impor neles o já mencionado dever de aplicar os critérios pela regra apontados para a identificação do direito (Hart, [1961] 2009, p.80; Coleman, 2001, p.367 ${ }^{51}$ ).

Uma nota é, contudo, necessária: deve-se distinguir o fato de que a regra de reconhecimento - como regra social - é dotada de autoridade, ou seja, gera razões para ação, e o fato de que o tipo (ou um dos tipos) de razão que ela provê consiste em um dever. Como nota Coleman, o ponto de vista interno (que será mais profundamente estudado na próxima seção) apenas explica como a prática social convergente do grupo reconhecedor gera razões, como um fato social pode dar origem a uma norma; Hart não propõe - e nem poderia - que o ponto de vista interno explique qual o tipo de razão que a citada regra social provê (Coleman, 2001, p.367). Para fazê-lo, Coleman propõe que se olhe além do ponto de vista interno e considere a estrutura da prática social que a regra governa (2001, p.370): é a natureza de uma prática conjunta (e não uma soma de práticas individuais), a natureza convencional (ao tema se retornará posteriormente) da regra de

${ }^{50}$ De modo não unânime. Por exemplo, Shapiro (2006, p.1166) afirma que o ponto de vista interno não explica a normatividade do direito. Mais ainda: acredita que Hart não parecia crer ser do escopo da teoria do direito prover tal explicação.

51 Jules Coleman parece ter abrandado a posição de que a regra de reconhecimento gera razões (ao menos em um sentido "forte”), conforme visto em discussão travada com Leslie Green e Brian Leiter retirada do blog de filosofia jurídica deste último (http://leiterlegalphilosophy.typepad.com/leiter/2008/02/dickson-on-the.html. Acesso em 29 de dezembro de 2014). As posições tomadas por Coleman, Leiter e Green não foram reafirmadas em trabalhos acadêmicos de que se tenha notícia, mas independentemente de como tenham colocado seus respectivos argumentos, ainda assim as ideias neles traçadas merecem ser expostas. Confirase, portanto, o trecho em que Coleman revisa sua posição

“Claro que eu acredito em regras reconhecedoras, mas, como Raz, eu não acredito em uma regra mestra de reconhecimento. Quando eu acreditava, eu também acreditava em duas outras coisas que não mais acredito. Eu acreditava que a regra tinha que oferecer razões no sentido completo (full) de razões; e eu acreditava que ela era uma convenção coordenativa. Mais tarde eu acreditei em um outro tipo de regra social, e.g. em uma Atividade Cooperativa Compartilhada. Em ambos os casos eu continuei a manter a visão de que ela oferecia razões em um sentido completo. Foi isso que eu abandonei

E ao abandonar isso eu abandonei as teses de convenção coordenativa e Atividade Cooperativa Compartilhada. Então eu desisti da ideia de que existe uma Regra de Reconhecimento, não da ideia de que existem regras reconhecedoras. Eu desisti da visão de que ela precisa ser uma regra que oferece razões; e, é claro, eu desisti das várias explicações do tipo de razão que ela oferece.” 
reconhecimento que explica a criação de razões no tipo deveres (Coleman, 2001, p.371).

Em resumo: ao impor deveres nos agentes relevantes para que considerem as normas identificadas como razões jurídicas autoritativas, ou seja, como razões peremptórias e excludentes para agir, a regra de reconhecimento parece dar conta da normatividade do direito. Por outro lado, a sua própria normatividade só pode ser explicada com base na aceitação da regra por parte dos agentes relevantes. Aceitar a regra de reconhecimento vem, como visto, a consistir em aceitar considerar certas normas como jurídicas, independentemente de seu conteúdo, como razões peremptórias para ação (Ruiz Manero, 1990, p.173).

\subsection{3}

\section{O problema da normatividade}

Como visto, a normatividade do direito decorre do fato que regra de reconhecimento última impõe um dever de seguir e aplicar o direito que é identificado de acordo com seus critérios de validade (Hart, 1982, p.156). Um primeiro problema é constatado ao perceber-se que, no seu modelo de regras sociais, a regra de um subgrupo (os officials) não pode criar deveres legais para o grupo inteiro (a população como um todo). Nas palavras de Lamond (2013, pp. 116-117):

Na concepção de regras sociais de Hart, a regra de um sub-grupo não cria deveres para o grupo inteiro. Sujeitos que não são autoridades públicas podem, claro, aceitar que devem seguir as regras jurídicas (e que autoridades públicas e cidadãos comuns devem seguir a regra de reconhecimento), mas isso levaria a uma outra regra social que indica que o direito deve ser obedecido - isto é, criaria uma obrigação social de obedecer o direito, não uma obrigação legal de obedecêlo. Uma obrigação legal, nesta concepção, é uma imposta pela regra de reconhecimento, e a regra de reconhecimento é uma regra das autoridades públicas.

Assim, a teoria tradicional apenas explicaria como os officials estão legalmente obrigados a seguir o direito, mas não como o povo está legalmente obrigado a seguir o direito (Beehler, 1976, p. 130; Himma, 2001, p. 289). Poderia ser dito que a normatividade do direito na população não decorreria da regra de reconhecimento, mas da aceitação do conjunto de regras primárias. Isso, entretanto, vai contra a segunda das condições necessárias e suficientes 
apresentadas pelo próprio Hart para a existência de um sistema jurídico: que as regras primárias sejam geralmente obedecidas pelo povo, não sendo necessário para a população aceitar o direito, mas apenas obedecê-lo (Hart, [1961] 2009, pp.150-151). Como visto, a normatividade do direito depende da aceitação da regra de reconhecimento; mas esta, como indica a teoria tradicional, é dirigida somente aos officials e não ao povo (Himma, 2001, p. 292).

Uma opção seria afirmar que o povo está obrigado a seguir o direito, mas não tem uma obrigação de fazê-lo. É este o caso do sistema jurídico mínimo de Hart, em que officials impõem um ordenamento jurídico contra a vontade de toda a população, um caso em que o povo somente obedeceria o direito (regras primárias e secundárias) por razões prudenciais. Como os officials aceitam e seguem a regra de reconhecimento, diz-se que esta conferiria normatividade a todo o direito e autoridade legítima para que as autoridades públicas imponham o direito na população.

O problema é que esta tese hartiana é vulnerável às mesmas críticas que o próprio faz a Austin (Páramo Argüelles, 1984, p. 278). Para Hart, a coerção pura e simples não pode gerar uma obrigação legal; afinal, é exatamente este o conteúdo de sua mais famosa crítica a Austin: o assaltante que coage o cidadão a passar o dinheiro obriga, mas não gera uma obrigação na vítima. Infelizmente para Hart, a situação não é diferente se o assaltante toma o ponto de visto interno em relação à sua autoridade para fazer tais ameaças. A atitude do assaltante não seria menos coerciva se ele acreditasse que tem autoridade ou legitimidade para fazer a ameaça $^{52}$, e não é menos coerciva que a atitude dos officials do sistema jurídico mínimo de Hart (Himma, 2003, p. 307; Páramo Argüelles, 1984, p. 319). Nas palavras de Schauer e Alexander (2009, pp.178-179):

Como é neste caso a representação do sistema jurídico de Hart diferente da representação Austiniana - o sistema jurídico como a "situação do assaltante ampliada" - que Hart expressamente rejeita? Afinal, as autoridades públicas só são "autoridades públicas" porque existe uma regra de reconhecimento que valida as regras que as declaram autoridades públicas; e a regra de reconhecimento, por sua vez, é apenas a regra de reconhecimento porque elas (as autoridades públicas) a tratam como tal. Assim, elas são autoridades públicas apenas em seu ponto de vista, não no ponto de vista dos cidadãos que não aceitam a regra de reconhecimento dessas autoridades públicas. Para os cidadãos, as “autoridades

\footnotetext{
${ }^{52}$ Por exemplo, se o assaltante acha que é Robin Hood, e rouba dos ricos para redistribuir aos pobres, corrigindo, assim, "injustiças históricas”.
} 
públicas” podem não ser diferentes de uma quadrilha de assaltantes. Se os cidadãos obedecem as autoridades públicas somente por medo mas consideram, digamos, um governante exilado como o legítimo - eles aceitam a regra de reconhecimento que valida o governo exilado e suas promulgaçãoes - por que deveríamos concluir que a regra de reconhecimento das autoridades públicas e as regras por ela reconhecidas formam o sistema jurídico que governa a população? Esta conclusão não estaria mais de acordo com a concepção de Austin do assaltante? Se apenas juízes e legisladores - que são "autoridades públicas" apenas em virtude das regras que eles (e talvez a 101st Airborne e o FBI) aceitam - precisam aceitar a regra de reconhecimento em ordem para as regras por ela reconhecidas formarem o sistema jurídico governante do resto da população, então a visão de Hart começa a lembrar uma versão em nuance da de Austin. E mesmo se as autoridades públicas aceitarem a regra de reconhecimento por razões puramente prudenciais - como medo do rei ou aspirações de promoção na carreira - a mesma conclusão não deve ser tirada?

Na crítica à teoria imperativa, Hart comprometeu-se não somente com a afirmação (que já bastaria para seus propósitos) que não é verdade, para todo sistema jurídico possível, que a obrigação legal seja puramente coerciva; ele optou por abraçar a tese de que é verdade, para todo sistema jurídico possível, que a obrigação legal não seja puramente coerciva. Ou seja, para além do claim que a obrigação jurídica não é essencialmente coerciva, Hart afirmou que a obrigação jurídica é conceitualmente não-coerciva. Esta segunda afirmação é incompatível com o sistema jurídico mínimo de Hart, pois nele a relação dos agentes públicos que internalizam as regras secundárias com os cidadãos que apenas obedecem as regras primárias é uma relação coerciva (Himma, 2001, p. 308). A sua noção de aceitação não permite a Hart distinguir entre um sistema jurídico mínimo baseado exclusivamente em termos de poder e um sistema baseado em termos de autoridade (Páramo Argüelles, 1984, p. 278).

Este é conhecido como o "Problema de Payne”, após ter sido indicado por Michael Payne em “Hart’s Concept of a Legal System” (1976, p. 381):

Por exemplo, se as autoridades públicas (uma fração da população) aceitarem de um modo geral as regras secundárias apenas pela razão de que sem sua cooperação voluntária eles não conseguiriam manter seu poder coercivo, e se eles coagem os cidadãos para obedecerem as regras primárias, então o sistema jurídico existe e seu poder coercivo reside na aceitação dos agentes públicos de sua autoridade. Esse é um sistema de poder sem autoridade e é consistente com o conteúdo mínimo do direito natural. Mas tal sistema de poder baseado em ameaças é precisamente o tipo de modelo de direito que Hart rejeita, e é claramente inconsistente com a caracterização de Hart de regras de obrigação.

O exemplo extremo do Problema de Payne é oferecido por Hodson (1976, p. 394). O autor imagina um sistema (“Outlandia”) controlado por um monarca (“Leviathan”) que impõe o seu sistema jurídico (composto de regras primárias e 
secundárias, inclusive uma regra de reconhecimento que reconhece tudo que Leviathan diz como direito) com base apenas no medo gerado em seus officials. Destes, Leviathan consegue aceitação por razões puramente prudenciais - eles têm medo de receberem uma dolorosa punição se não guiarem seu comportamento pelas regras impostas pelo monarca, estão apenas preocupados em evitar a punição. Os officials por sua vez, impõem o direito reconhecido na população de Outlândia, tal qual ocorre no sistema jurídico mínimo de Hart. Para Hodson, a única diferença entre este cenário extremo de Outlandia e de algumas ditaduras ou do sistema mínimo é a tecnologia usada por Leviathan para controlar o aspecto psicológico de seus officials, devendo, por este modo, ser também considerado um sistema jurídico ${ }^{53}$ segundo a leitura canônica, pelo atendimento dos elementos formais (i) aceitação (ainda que por motivos puramente prudenciais) das regras secundárias pelos officials e (ii) obediência ao direito pela população. Tal sistema revela-se inconsistente quando visto à luz das críticas de Hart a Austin, e o fato de que a coerção alcança também os officials põe em dúvida a consistência dos critérios oferecidos na leitura canônica.

A situação da população em geral em Outlândia, no sistema mínimo de Hart ou no sistema de Austin e seu soberano é similar (Beehler, 1976, p. 127): ela é obrigada a seguir o direito, não tendo uma obrigação legal de fazê-lo. Deste modo, o sistema mínimo de Hart, em que somente os officials aceitam a regra de reconhecimento, não é menos coercitivo que o sistema jurídico de Austin (Himma, 2001, p. 307, Shiner, 1992, p.160, Payne, 1976). Para desenvolver uma teoria que desse conta de todos os sistemas jurídicos possíveis, Hart parece ter construído um ponto central de sua teoria baseando-se em um caso extremo e de penumbra (o sistema jurídico mínimo), um caso que, na verdade, é patológico

${ }^{53}$ Oferece-se aqui uma versão mais caridosa do argumento de Hodson, relevando leituras incorretas de Hart (como a que equipara aceitar a endossar as regras secundárias como legítimas (1976, p. 392)) e uma construção questionável à luz do pós-escrito d’O Conceito de Direito: seria possível afirmar que não há regra de reconhecimento em Outlandia pela inexistência de um aspecto convencional na prática convergente de aceitação entre os officials; ou seja, que pelo fato de os demais atuarem do mesmo modo não constituir ao menos parte das razões para agir não seria possível falar em uma regra de reconhecimento no sentido que colocado por Hart no pós-escrito Esta objeção pode ser afastada se consideramos, como visto, que o debate a respeito da ontologia da regra de reconhecimento não apresenta uma resposta clara e definitiva, e que ela (assim como a incorreta leitura a respeito do conceito de aceitação) não afeta em nada a questão da normatividade do direito. 
(McBride, 1965, p. 386) segundo os próprios conceitos que havia estabelecido no início d’O Conceito de Direito.

Poderia ser argumentado aqui que a analogia é imperfeita, que o assaltante nunca se sente legitimado a fazer a ameaça e que as autoridades públicas assim sentem-se. Mas essa é uma afirmação empírica e absolutamente contingente, pois, como visto, é possível conceber um assaltante que parta da crença de que ele está legitimado a fazer as ameaças e um ordenamento jurídico em que todos os assaltantes se considerem legitimados a fazer ameaças, e essa mera possibilidade parece ser suficiente para derrubar tal objeção. Seria possível ainda insistir na diferenciação dos casos em dois aspectos: (1) as diretivas do sistema jurídico mínimo de Hart são gerais e abstratas; (2) a regra de reconhecimento é aceita por prover standards de comportamento oficial. Contudo, por mais que seja possível ver uma separação conceitual entre as situações, ela não é suficiente para justificar a caracterização do sistema mínimo como não coercivo (Himma, 2001, p. 309).

\section{3}

\section{Quem é o grupo reconhecedor relevante?}

Até agora, ao tratar de quem é o responsável pela prática social que funda a regra de reconhecimento, fez-se, na maior parte dos $\operatorname{casos}^{54}$, menção apenas genericamente ao "grupo reconhecedor relevante" ou "comunidade reconhecedora relevante”, sem especificar que tipo de grupo é este. Neste último tópico, serão analisadas as propostas de compreensão a respeito do grupo reconhecedor relevante, encaminhando a discussão para o próximo capítulo.

Hart não parece identificar precisamente o grupo que tem em mente, de modo que é possível achar passagens contraditórias na versão original e no pósescrito d'O Conceito de Direito, sendo essa uma questão que parece não ter recebido a devida atenção de seus comentadores (Adler, 2006, p.729). Entretanto, parece que, para Hart, dois grupos se destacam: o dos officials e dos juízes (Shapiro, 2009, p. 235 e Raz, 1979, pp. 92ss). Isso porque, como já mencionado, para o autor d'O Conceito de Direito, apenas a aceitação destes grupos é condição

\footnotetext{
${ }^{54}$ Excetuando-se os casos de citações em que o autor citado especifica algum dos grupos.
} 
necessária para a existência de um ordenamento jurídico; é possível, mas não necessário, que as pessoas que não possuem poderes legais (os leigos, cidadãos comuns) compartilhem a aceitação da regra de reconhecimento (MacCormick, 2008, p.34; Hart [1961] 2009, pp.150-151).

Segundo Hart, condicionar a existência de um ordenamento jurídico à aceitação da regra de reconhecimento por cidadãos comuns num Estado moderno complexo seria “insistir numa ficção”, pois “uma grande parcela dos cidadãos comuns - talvez a maioria - não tem uma concepção geral da estrutura jurídica ou de seus critérios de validade. A lei à qual o cidadão obedece é algo que conhece apenas como 'a lei'” (Hart [1961] 2009, p. 147). Este “argumento da ignorância” encontra forte respaldo nos jusfilósofos hartianos, que reconhecem a complexidade dos ordenamentos jurídicos modernos e a ignorância da população em geral: a maioria do povo parece mal saber o que diz a Constituição, quanto mais detalhes de complexos critérios não formalmente enunciados de validade da própria Constituição (Shapiro, 2001, p. 154), ocupando os officials lugar central no sistema jurídico, enquanto o povo é relegado à margem, bastando que ele assegure a eficácia geral do ordenamento (Galligan, 2007, p.121).

Assim, chega-se a mais uma situação de aparente autorreferência: é a prática das autoridades públicas que indica o que as autoridades públicas devem fazer. Mesmo que o povo tente influenciar tais práticas por meio do voto ou outras formas de expressão popular, estas são necessariamente irrelevantes, a não ser que sejam validadas pelas práticas das autoridades públicas. O povo não teria nenhum papel na definição do próprio lugar nem mesmo nas questões constitucionais (novamente no sentido empregado por Gardner (2011)) a não ser que as autoridades públicas venham a conceder ao povo alguma função nesses processos (Adler, 2006, p.722), o que seria de difícil ocorrência em sociedades complexas onde as práticas associadas com a definição e identificação dos critérios de validade parecem envolver cada vez mais processos ininteligíveis para a grande maioria da população (Waldron, 1999, p.178).

Por ora, não se pretende argumentar a favor de uma visão que inclua o povo no grupo reconhecedor relevante: esta tarefa ficará para o próximo tópico. Nesta seção, portanto, a questão será delineada em termos descritivos, apresentando-se as quatro propostas existentes na doutrina: os agentes públicos (officials); os juízes; o povo; e a posição grupo-relativa de Matthew Adler. 
Na primeira versão d’O Conceito de Direito, Hart parece indicar que são apenas os officials - as "autoridades públicas” ou "agentes públicos” os responsáveis pela aplicação do direito dentro e fora das cortes ([1961] 2009, pp. 148, 150, 151, entre outros). Os comentadores de Hart identificam nesta categoria desde Chefes do Executivo e Parlamentares até meros funcionários públicos encarregados de serviços burocráticos e de aplicação do direito como policiais, fiscais,etc. (Greenwalt, [1987] 2009, p. 38; Waldron, 1999, p. 177; Coleman, 2001, p.357; Shapiro, 2002, p. 426; Wacks, 2005, p. 74; Adler, 2006, pp.731-732; Himma, 2009, p. 98; Páramo Argüelles, 1984, pp.230-231; Marmor, 2011, p.55; Lamond, 2013, p. 111).

Isso se deve ao fato de que, para esses autores, é insuficiente para a eficácia normativa do sistema jurídico que apenas os juízes aceitem a regra de reconhecimento. Em outras palavras, os juízes dependem de outros agentes públicos para aplicar (enforce) suas decisões, o que ficaria evidente em conflitos entre tribunais e outros agentes públicos. Nas palavras de Himma (2003, p. 154):

É importante perceber que autoridades jurisdicionais não são os únicos participantes cujos comportamentos e atitudes determinam a existência e o conteúdo da regra de reconhecimento. Enquanto alguns positivistas pensam que a regra de reconhecimento não é mais que um costume judicial, isso é um erro. A autoridade das cortes é limitada, por exemplo, pela aceitação dos agentes públicos que possuem autoridade para aplicar o direito. Se um número suficiente destes agentes públicos se recusa a garantir decisões judiciais com o poder de polícia estatal, então essas decisões carecem do tipo de efeito que conceitualmente supõe-se que diretivas legais possuem. Uma vez que a autoridade legal das cortes é limitada pela aceitação de outras autoridades públicas, a existência e o conteúdo da regra de reconhecimento dependem da prática conjunta de ambos juízes e demais agentes públicos.

Por outro lado, se passagens em que Hart menciona apenas juízes ou tribunais podem ser achadas no texto original d'O Conceito de Direito (entre outras, [1961] 2009, pp. 140, 149), foi apenas na segunda edição do livro, em seu pós-escrito que Hart expressamente adotou esta versão, afirmando que a existência e autoridade da norma de reconhecimento dependem do fato de sua aceitação pelos tribunais ([1961] 2009, p.323); e em passagens como "norma de reconhecimento, que é na verdade uma forma de norma jurídica consuetudinária que existe apenas quando é aceita e praticada nas operações de identificação e aplicação das leis pelos tribunais” ([1961] 2009, p.330); “consenso geral existente entre os juízes sobre os critérios para a identificação das fontes do direito ao fato de compartilharem a aceitação das normas que fornecem esses critérios” (Hart, 
[1961] 2009, p. 344); “forma convencional de consenso judicial” (Hart, [1961] 2009, p.344); “identificação judicial das fontes do direito” (Hart, [1961] 2009, p.345); “regra convencional de reconhecimento cuja existência e autoridade dependem de sua aceitação pelos tribunais” (Hart, [1961] 2009, p.345).

Mesmo considerando esta "virada jurisdicional” dada por Hart, seus seguidores parecem bem divididos entre os que consideram os officials e os que tomam apenas os juízes como relevantes para a prática do reconhecimento, entre os quais Ruiz Manero (1990, p. 136), Christopher Kutz (2001, p. 461) e Raz (1980, p. 190), que os chama de “órgãos primários de aplicação do direito”.

Mais especificamente, explica Shapiro (2001, p. 155), o que se confundiria ao incluir os demais officials no grupo reconhecedor relevante são os processos de internalização da regra de reconhecimento e das demais regras secundárias. Regras de reconhecimento existem somente quando sistemas jurídicos existem, e sistemas jurídicos existem somente quando certas condições são atingidas, como outros officials internalizando as regras secundárias que lhes conferem poderes (além, é claro, da obediência pela população das regras reconhecidas). As cortes gerariam regras de reconhecimento não por causa de uma superioridade política ou em termos de autoridade jurídica, mas sim porque possuem a capacidade de guiar o próprio comportamento pela regra que é criada pela sua prática convergente - "é o poder sobre elas mesmas, e não sobre os outros, que fundamenta sua autoridade”. Contudo, como indicado, essa regra não é a regra de reconhecimento até que todas as condições de existência do sistema jurídico são atingidas (Shapiro, 2001, p. 155).

É entretanto possível achar passagens n’O Conceito de Direito em que Hart também menciona sujeitos privados desprovidos de poderes legais como membros da comunidade reconhecedora relevante, tais como: "sua existência fica demonstrada pela forma como se identificam normas específicas, seja pelos tribunais ou outras autoridades, seja por indivíduos particulares ou seus advogados e assessores jurídicos” ([1961] 2009, p. 131); "Podemos perguntar se os tribunais, corpos legislativos, autoridades ou cidadãos comuns costumam realmente utilizá-la na Inglaterra como uma norma última de reconhecimento" (Hart, [1961] 2009, p.138); “Não há dúvida que a prática de juízes, autoridades $e$ outros na qual consiste a existência real de uma norma de reconhecimento" ([1961] 2009, p. 140); “a norma de reconhecimento só existe como uma prática 
complexa, embora normalmente harmoniosa e convergente, que envolve a identificação do direito pelos tribunais, autoridades e indivíduos privados" ([1961] 2009, p. 142).

Matthew Adler (2006, p.725) chama os teóricos que colocam as práticas dos cidadãos como fundação para o direito como constitucionalistas populares em um sentido profundo (deep popular constitutionalists). Para esses autores, o status do povo na base do sistema jurídico (Adler, 2006, p.719) não adviria de um argumento normativo, de uma melhor forma de entender um determinado sistema constitucional (particularmente o norte americano) através de uma argumentos políticos e morais - tal qual defendem os constitucionalistas populares em um sentido raso (shallow popular constitutionalists) -, mas sim de um argumento conceitual, uma afirmação de uma verdade conceitual a respeito da própria natureza do direito (Adler, 2006, p.726). Aos constitucionalistas populares profundos se oporiam os supremacistas judiciais profundos (deep judicial supremacists) - autores como Raz, Kutz e Hart no pós-escrito - para quem somente a prática de juízes conta para a definição do direito válido; suas preocupações não estão no conteúdo do direito constitucional, mas em uma questão teórica mais profunda, que repousa na interseção entre a teoria do direito e a teoria constitucional (Adler, 2006, p.720). Supremacistas judiciais rasos (shallow judicial supremacists), tal qual os constitucionalistas populares rasos, estão preocupados com argumentos de arranjos constitucionais, de constitutional decisionmaking (Adler, 2006, p. 798). Um mesmo autor pode ser um constitucionalista popular profundo e um supremacista judicial raso, como parecem ser Frederick Schauer e Larry Alexander. Basta que ele admita que o povo necessariamente reconheça como direito válido um arranjo institucional em que as decisões da Suprema Corte vinculem todos os demais operadores do direito em suas interpretações. No próprio artigo em que defendem que a Suprema Corte tem a palavra final sobre questões constitucionais utilizando-se de argumentos relativos à estabilidade e coordenação, os autores citados parecem adotar a postura que reconhece a sociedade civil como grupo reconhecedor relevante ou, nas próprias palavras, como “desenhista institucional” (Schauer e Alexander, 1997, p.1379, nota 85).

Ainda, em trabalho posterior, Schauer (1998) sugere que o locus da regra de reconhecimento seria melhor situado na sociedade, ou "nas fontes de força em 
uma sociedade" (o Poder Executivo, os militares e os costumes inseridos na consciência da comunidade, etc.), de cujo suporte contínuo o poder do sistema jurídico depende (Schauer, 1998, p.72). Atienza e Ruiz Manero (1998, p. 149) falam em uma fundamental atitude de aceitação por parte de juristas, da classe política e do público em geral.

Para Schauer, se é possível conceber um sistema onde os juízes só usam o direito não pela sua força normativa, mas por influências externas, como o desejo de agradar a mídia ou o resto sociedade (que deseja ver o direito aplicado) em troca de auto-promoção, de modo que a única razão para os juízes adotarem o ponto de vista interno é prudencial; se esse sistema hipotético é jurídico, é “direito” (e Schauer diz que sim), então seria possível ver que a existência e validade do direito são diferentes de sua autoridade - este direito concebido no exemplo seria um direito sem autoridade, ao menos se o locus da autoridade são os juízes. Assim, a possibilidade conceitual de que os juízes atuem aplicando o direito para também serem bem vistos pela mídia, pela classe política, pela doutrina e pela sociedade como um todo mostra que os juízes não são o locus apropriado para a regra de reconhecimento. Na verdade, "a regra de reconhecimento existe na medida que é internalizada pela sociedade, pelos políticos, pelos advogados, ou pela doutrina” (Schauer, 1998, p. 74). Nas palavras de Struchiner (2005, p. 74):

Na medida em que juízes, como todos nós, são vaidosos, e querem agradar a jornalistas, políticos, advogados e cidadãos de uma maneira geral, enfim, a todos aqueles que são responsáveis por torná-los figuras reverenciadas ou fazer com que caiam no esquecimento, então o que conta como o critério último de identificação do direito é o que foi internalizado pela sociedade como um todo.

Além disso, a figura dos juízes e autoridades públicas que baseia as concepções juriscêntricas não sobrevive a uma ciência política ou sociologia dos tribunais mais apurada. Assim como legisladores se importam com sua reeleição, também juízes procuram promoções (quando também os juízes não dependem de eleições, como nos Estados Unidos). Do mesmo modo, detentores de altos cargos no Poder Executivo e até mesmo funcionários públicos de médio e baixo escalão podem possuir algum tipo de vinculação com o público em geral. Para Adler (2006, p.774), “a identificação Raziana/Kutziana dos juízes como a comunidade reconhecedora canônica, tomada como um axioma de prática social cientítica, é profundamente problemática”. Ainda que não sejam teses empíricas, mas 
conceituais, deve-se frisar o compromisso do positivista hartiano com uma teoria que possua uma capacidade explicativa do fenômeno jurídico, em especial uma teoria que seja compatível com o constraint hermenêutico.

Por fim, cabe destacar a posição "grupo-relativa” desenvolvida por Matthew Adler (2006), tratada mais como um caso de "teoria especial” do direito, aplicada especificamente ao caso norte-americano. Adler não chega a afirmar que a posição grupo-relativa é uma verdade conceitual para todo e qualquer ordenamento jurídico em todos os mundos possíveis, mas apenas que este parece ser o caso para o direito norte-americano. Seu esforço argumentativo é de demonstrar que, na história constitucional norte-americana, vários grupos diferentes influenciaram e continuam a influenciar a prática de reconhecimento, mesmo divergindo profundamente em muitos casos. Para ele, a prática de reconhecimento não é monopólio de um determinado grupo, mas uma atividade complexa partilhada por diversos setores da sociedade que podem divergir entre si estando comprometidos com um mesmo quadro geral de instituições jurídicas e políticas que permita falar-se em um único sistema jurídico (e não um caso de patologia). $\mathrm{O}$ autor adota como base ontológica para sua teoria a concepção de Atividades Cooperativas Compartilhadas do filósofo Michael Bratman ${ }^{55}$, mas afirma ser possível conceber a tese grupo-relativa a partir de uma concepçãoo convencionalista, de regras constitutivas Searlianas ou da Teoria das Regras Sociais como Práticas.

Adler (2006, p.749) rejeita ambos os pólos "profundos”, afirmando que nem somente cidadãos, nem somente juízes conformam a comunidade reconhecedora; para ele, não há um único grupo reconhecedor canônico, mas grupos diferentes (de todas as esferas) podem se engajar em práticas reconhecedoras que estejam de algum modo estreitamente conectadas (por exemplo, dando força substancial ao mesmo texto básico, referindo-se a ele pelo mesmo nome, aplicando-o no mesmo território), mas ainda assim divergirem em relação ao seu conteúdo (2006, p. 746). Haveria, pois, uma pluralidade de sistemas menores, constituídos pelas práticas dos diferentes grupos

${ }^{55}$ Michael E. Bratman, "Shared Cooperative Activity," The Philosophical Review, Vol. 101, No. 2, Abril 1992 e "Shared Intention," Ethics n.104, Outubro 1993, pp. 97-113. 
reconhecedores, e que, conjuntamente, formariam o que se chama de "direito norte-americano” (2006, p.749).

Assim, a prática dos diferentes grupos geraria diferentes “corpos jurídicos” constitucionais que compartilham uma fundação em comum no texto da constituição americana e em outros fatores, como o reconhecimento das instituições de poder inerente, o reconhecimento da validade de alguns textos legais, etc, mesmo que divirjam de modo relevante quanto a várias questões de conteúdo (Adler, 2006, pp.747-748).

É, portanto, preciso tratar a teoria grupo-relativa com certo cuidado, pois, como visto, seu próprio autor a coloca não como uma solução conceitual para um problema geral e abstrato, mas como um exercício de sociologia jurídica descritiva na análise de uma questão de teoria do direito e teoria constitucional.

Em resumo, neste tópico procurou-se apresentar as quatro concepções apresentadas na doutrina para a identidade do grupo reconhecedor relevante: (i) a concepção original de Hart (e que parece contar com a adesão da maioria dos autores na tradição positivista hartiana), que afirma serem os officials, as autoridades públicas judiciais e não judiciais igualmente responsáveis pelo reconhecimento; (ii) a posição adotada por Hart no pós-escrito d'O Conceito de Direito e compartilhada por Raz e Kutz, que vê nos órgãos jurisdicionais o grupo reconhecedor relevante; (iii) a posição de Schauer e Alexander, que estende à sociedade como um todo a prática de reconhecimento; e (iv) a teoria gruporelativa de Adler, que afirma existirem vários grupos reconhecedores com práticas concomitantes e paralelas, produzindo regras de reconhecimento diferentes mas unidas em um mesmo ordenamento jurídico.

\subsection{1}

Ignorantes, ovelhas e a aceitação do direito

É chegada a hora de analisar as duas objeções levantadas por Hart e a maioria de seus seguidores contra a inclusão do povo no grupo reconhecedor relevante. Apesar de conceitualmente diferentes, ambas são muito próximas, fortemente relacionadas, e costumam vir conectadas na rejeição da inclusão do povo no grupo reconhecedor relevante. À primeira delas já se fez referência no tópico anterior, e diz respeito ao argumento hartiano ([1961] 2009, p. 147) de que 
o povo é ignorante, não possui o conhecimento jurídico necessário para entender os detalhes técnicos complexos que fazem parte da atividade de reconhecimento.

Ironicamente, o próprio Hart chegou a advogar posição contrária em obra anterior (1958, pp. 89-90), tendo sido por isso criticado por Hughes (1960). Hart incorporou a crítica n’O Conceito de Direito([1961] 2009, p.80):

"mas num Estado moderno seria absurdo pensar que a maioria da população, por mais que seja obediente à lei, tenha compreensão clara das normas que especificam as qualificações de uma classe de pessoas, em contínua mudança, autorizadas a legislar. Falar da "aceitação" dessas normas pela população da mesma forma como os membros de uma pequena tribo poderiam aceitar a norma que outorga autoridade a seus chefes sucessivos significaria atribuir aos cidadãos comuns uma compreensão dos temas constitucionais que eles põem não possuir. Só exigiríamos tal compreensão das autoridades ou dos especialistas do sistema, ou seja, os tribunais, que têm a responsabilidade de determinar o que é o direito, e os advogados e juristas, que o cidadão comum consulta quando quer se informar.

Este "argumento da ignorância" é também conhecido como o "Problema de Hughes” (McBride, 1965, p. 385; Shiner, 1992, p. 162). Hughes (1960, p. 1011) parte da observação de que na maioria dos sistemas contemporâneos os cidadãos comuns possuem uma relação mediata com o direito: eles não lêem leis e decretos, mas adquirem conhecimento jurídico "de um modo acidental”, ou, pior ainda, sequer possuem ideia do “esquema de autoridade” vigente (Green, 1996, p.1700). Ademais, identificar normas fundamentais seria uma questão controvertida mesmo para os próprios juristas, estando completamente fora do alcance da massa dos cidadãos (Waldron, 1999, p. 178); a preocupação com as normas fundamentais de um ordenamento jurídico seria característica apenas dos juristas e officials de alto escalão, de modo que incluir o povo no grupo reconhecedor relevante “desafiaria a experiência ordinária” (Hughes, 1960, p. 1013). O autor (1960, p. 1012) afirma que:

Na pirâmide das normas, o cidadão está, na maior parte dos casos, na base; no topo a norma fundamental está acima das nuvens. Há algo de artificial na afirmação de Hart de que a existência de uma norma fundamental é a sua aceitação pela generalidade da população. Pode esta existência consistir na aceitação da norma pelo povo que não tem ciência dela?

Hughes ainda procura apresentar alguns exemplos históricos e outros hipotéticos para demonstrar que não é somente nos ordenamentos jurídicos modernos que ocorre o problema, mas que esta característica da população em geral é um dado sociológico e histórico, não devendo por isso ser menosprezado. 
Ele inicia argumentando que o povo romano não poderia ter noção das muitas mudanças ocorridas na norma fundamental do seu direito em períodos conturbados, como a queda da República e a ascenção de imperadores, e com a "sucessão de líderes de guerra superimposta na tradicional autoridade do senado e da magistratura convencional” (Hughes, 1960, p. 1012). Indaga, ainda, se "um pequeno fazendeiro da Etrúria” poderia ter conhecimento das constantes e rápidas transições, e se poderia ser atribuído a ele algum tipo de participação no sistema jurídico romano. O exemplo romano não é de todo problemático, pois é possível construir uma norma fundamental de reconhecimento compartilhada pelos súditos romanos de que o direito é tudo que vem de Roma, seja o aparato governamental controlado por quem quer que seja. Ainda, é possível argumentar que as rápidas mudanças não poderiam ser captadas nem por uma regra que seja reconhecida apenas pelos officials, pois muitas vezes só é possível reconhecer a alteração da regra de reconhecimento ex post facto.

Há, entretanto, uma primeira falha mais grave no argumento de Hughes: para que o povo seja inserido no grupo reconhecedor relevante, não é necessário que absolutamente todos os integrantes da população de um local concordem na identificação das normas mais básicas de seu direito (MacCormick, 2007, pp. 5152). Não é necessária uma conformidade unânime dentre os participantes do grupo reconhecedor, sendo possível existir uma regra mesmo quando uma minoria se recuse a encará-la como padrão de conduta (Hart, [1961] 2009, p.75). Se é possível afirmar que não se exige unanimidade entre o grupo de officials quanto aos critérios de reconhecimento, podendo ocorrer desvios pontuais e que não ameacem o caráter convencional da regra, também aqui será possível falar em uma aceitação pela população sem que ela seja unânime. Do mesmo modo como a possibilidade conceitual da existência de um official (ou um grupo minoritário de officials) desviante que se recuse a aplicar os critérios identificados pela regra de reconhecimento não desnatura a tese de que os officials são o grupo reconhecedor relevante, a existência de sujeitos marginalizados da sociedade que deliberadamente desviem ou não façam ideia do que é o direito local não pode desnaturar a tese que coloca o povo no grupo reconhecedor relevante.

O segundo exemplo apresentado por Hughes envolve a ocupação de um território por um inimigo estrangeiro, que deixa províncias distantes da capital isoladas. Nestas, os magistrados continuariam a aplicar o direito do governo 
deposto e que este seria um caso de vida post mortem do direito, como da "galinha que tem sua cabeça cortada e continua andando" (Hughes, 1960, p. 1013). Em outra passagem, Hughes (1960, p. 1018) cita a ocupação nazista de países europeus como um cenário de dificuldade para teorizar a aceitação popular do direito. Em ambos os casos, parte da população não aceitava o direito reconhecido pelos officials impostos pelo regime invasor, que tinha sua efetividade calcada apenas na força, na coerção. Aqui, além de trazer exemplos que são claramente casos patológicos do sistema jurídico na própria definição de Hart ([1961] 2009, p. 152), é retomado o problema da normatividade (essas populações são obrigadas mas não possuem uma obrigação de seguir o direito).

Se os exemplos apresentados por Hughes não são os mais convincentes, deve-se retornar para a análise teórica do problema da ignorância. Afastá-lo, neste plano, somente pode ser feito argumentando-se que (i) ou o povo não é ignorante, ou (ii) a sua ignorância não o impede de aceitar, pois o que lhe é exigido não é um conhecimento detalhado dos critérios jurídicos. Como a primeira opção é inviável (pois importaria em dizer que não é concebível um sistema jurídico em que a população seja ignorante quanto aos critérios últimos de reconhecimento), cabe analisar a viabilidade teórica da segunda opção. Neste sentido, tratar a aceitação como uma atividade intelectualmente complexa importa em pressupor um requisito conceitual que Hart não parece ter indicado em seus escritos. Pressupor este requisito implícito de “conhecimento jurídico mínimo” e dizer que é condição necessária para a aplicação do conceito de 'aceitação' que os sujeitos tenham um conhecimento razoável das operações jurídicas é, entretanto, inviável à luz da própria teoria hartiana. Isto porque, se assim fosse, os cidadãos jamais poderiam aceitar regras secundárias ou até mesmo primárias (Payne, 1976, p. 309). Lembrese que Hart ([1961] 2009, p. 329) conceitua aceitação como uma "atitude normativa específica” em relação a certos padrões de conduta, consistindo na “disposição permanente dos indivíduos de aceitar esses padrões de comportamento tanto como orientações para sua própria conduta”. Tomar um padrão como razão para ação não parece pressupor um conhecimento técnico específico a seu respeito. Recorde-se o que foi dito anteriormente que aceitação não é uma questão de "tudo ou nada”, mas “uma noção variável e condicional que pode ser mais forte ou mais fraca, mais ou menos contingente” (Galligan, 2007, p. 
94), e que a natureza e qualidade da aceitação da regra de reconhecimento são “uma grande variável no estudo social do direito” (Galligan, 2007, p. 96).

É necessário, portanto, tomar os conceitos de ‘aceitação' e seu correlato 'ponto de vista interno' pelo que de fato são. São apenas exigidos (i) o elemento cognitivo (representado pelo reconhecimento do padrão); e (ii) o elemento crítico (de conformidade ao padrão nas circunstâncias devidas - conformidade esta que, como visto, pode ser pelo caráter convencional da regra de reconhecimento condicional à aceitação do mesmo padrão pelos demais agentes). Como será visto adiante, é preciso apenas que os cidadãos comuns sejam capazes de identificar a existência de um padrão de critérios últimos de validade jurídica (ainda que eles não consigam expressar com precisão estes critérios ou que sequer entendam os detalhes da relação de validade jurídica para além do simples “isto é o direito, pois as demais pessoas da comunidade assim o consideram”) e estejam dispostos a guiar suas condutas por este padrão.

A segunda objeção levantada por Hart contra a possibilidade conceitual de inclusão do povo no grupo reconhecedor relevante diz respeito ao caráter eminentemente passivo da relação dos cidadãos leigos com o direito. É célebre a metáfora usada pelo professor de Oxford (Hart [1961] 2009, p. 151):

Num tal sistema complexo, só as autoridades aceitariam e utilizariam os critérios de validade jurídica do sistema. Uma sociedade assim poderia ser deploravelmente subserviente e acarneirada, e os carneiros poderiam acabar no matadouro; mas não há motivos para pensarmos que não poderia existir ou para negar-lhe a qualificação de sistema jurídico

Essa “conformidade ovina” (Waldron, 1999) ao direito, característica do ponto de vista externo, supõe uma adesão cega, automática e acrítica e, mais importante, que assim seja de um modo permanente (Shiner, 1992, p. 164). Apesar de conceitualmente possível, isto não parece proceder na esmagadora maioria dos casos de sistemas jurídicos históricos e modernos. Aqui, Hart parece pecar do mesmo modo que acusa Austin de fazê-lo: "a distorção como preço da uniformidade” ([1961] 2009, p. 52). Hart paga um preço alto para encaixar todas as hipóteses de sistemas jurídicos possíveis em seu sistema jurídico mínimo, não só pelos problemas da circularidade e normatividade, mas ao perder considerável poder explicativo da realidade jurídica construindo seu modelo com base em um exemplo extremo. 
Caso o compromisso com a "sociologia jurídica descritiva” seja levado a sério, uma proposta na tradição hartiana deve levar em conta a potencialidade explicativa de uma teoria no mundo dos fatos. Assim, se o próprio fundamento para a mudança de posição de Hart entre "Legal and Moral Obligation” (1958) e “O Conceito de Direito” (1961) foi a capacidade explicativa de sua teoria (recorde-se que Hart fala em não "insistir numa ficção (Hart [1961] 2009, p. 147)), parece ser viável reconsiderar a posição sob os mesmos motivos.

Isto porque a efetividade de qualquer sistema jurídico depende, em último caso, "nos interesses comuns da população participante e no reconhecimento destes interesses, refletidos na contínua predisposição para apoiar as prescrições e procedimentos do sistema” (McDougal e Lasswell, 1959, p. 5). Mesmo as ditaduras mais cruéis do mundo moderno sempre se preocuparam em conseguir a adesão de boa parte da população, seja criando um interesse mútuo com parte da população, seja apelando para sentimentos como patriotismo e ódio por inimigos externos ou internos. Somente a força bruta não é suficiente para manter um sistema jurídico, apesar de necessária em muitos casos (Hughes, 1960, p. 1018).

Assim, o argumento de que é só o conjunto de atitudes e opiniões dos officials qua officials que importa, e que, portanto, somente é necessário e suficiente que eles aceitem a regra de reconhecimento última só se verifica até certo ponto - o ponto em que tais opiniões e práticas passem a interferir nas bases do sistema político-jurídico aceitas pelo povo, nos pressupostos de validade (Schauer, 1995) do ordenamento, de tal modo que não se fale mais em uma regra de reconhecimento e um ordenamento, mas de um caso patológico de sistema jurídico.

Nas situações de normalidade, parece que somente a opinião dos officials importa, pois, quando confrontada com a opinião pública, prevaleceria ${ }^{56}$. A normalidade é mantida mesmo que ocorram decisões juridicamente "erradas" (segundo a própria regra de reconhecimento) e que essas decisões sejam obedecidas, ainda que justificadamente criticadas. Mas essa obediência pode

\footnotetext{
${ }^{56}$ Sem considerar as posições que indicam que os officials sao permeáveis à opinião púublica. Ver Schauer (falando conceitualmente, em "Positivism Through Thick and Thin”, 1998, pp.73-74) e de estudos de "sociologia juridica descritiva" como os de Barry Friedman (The Will of the People: How Public Opinion Has Influenced the Supreme Court and Shaped the Meaning of the Constitution. New Yotrk: Farrar, Straus and Giroux, 2009).
} 
também indicar (i) que a divergência não foi suficientemente profunda para caracterizar duas regras de reconhecimento distintas (o caso patológico descrito por Hart ([1961] 2009, p. 157), e (ii) que o povo aceita uma regra de reconhecimento em cujo ordenamento jurídico os juízes possuem tal autoridade, a de decidir contra a vontade popular ${ }^{57}$ em determinadas questões, mas não em todas, não quando a decisão/conduta dos officials interfere nos pressupostos de validade do ordenamento local. O problema ocorre na situação extrema de divergência entre regras de reconhecimento aceitas pelo povo e pelos officials; em outras palavras, na ocorrência de "golpes", que geram casos patológicos de sistema jurídico. Ora, se toda situação de descompasso entre a regra de reconhecimento reconhecida pelos officials e a regra de reconhecimento reconhecida pelo povo for considerada uma situação patológica, é possível afirmar que para que um sistema não seja patológico é preciso da aceitação da regra de reconhecimento de um modo minimamente congruente entre o setor público e a população.

Isso parece ser verdadeiro quer considere-se o conceito de officials apenas englobando os juízes, quer englobando todos os agentes públicos. Tome-se o exemplo brasileiro: considere-se a hipótese em que Supremo Tribunal Federal (no que é seguido por todos os tribunais) começa a aplicar regras inexistentes na Constituição, como, por exemplo, que as suas decisões importam na emenda à Constituição. Esta “nova interpretação” revela na verdade uma nova regra de reconhecimento, aceita apenas pelo Poder Judiciário, e é de se predizer que haja a resistência dos outros poderes e do povo para aplicar o "novo direito". Tal conduta desviante será objeto de crítica justificada, e uma crise institucional será instaurada, com as duas regras de reconhecimento (a anterior, e a "nova", que confere tais poderes ao Supremo Tribunal Federal) competindo entre si. A diferença para a concepção de officials como agentes públicos incluindo os demais poderes constituídos é apenas de grau, não de espécie. Considere-se a hipótese de uma revolução “completa”, em que os três poderes da República em todas as esferas apoiam a Constituição Noelina e declaram Noel Struchiner o

\footnotetext{
${ }^{57}$ Como parece ser o caso nos ordenamos jurídicos modernos que possuem constituições escritas com certo grau de rigidez. É digno, pois, de nota, que a doutrina constitucional no Brasil, EUA e Europa é extensa ao falar no caráter contramajoritário do Poder Judiciário.
} 
Presidente do Brasil (Struchiner, 2005, p. 77). Como no exemplo anterior, haverá resistência da população, crítica justificada ao desvio e uma possível guerra civil. Não é, como indicado, qualquer decisão errada ou até mesmo aberrante que pode levar a essa insurgência. Como Schauer e Alexander (2009, pp.190-191) mostram, apenas decisões “substantivamente obnóxias” que representem uma má-fé dos officials na prática de aplicação da constituição, mesmo que a maior parte da população divirja da interpretação dada. De todo modo, a situação patológica se mantém até que o "golpe” seja derrotado ou até que a maior parte da população aceite esta nova regra, revelando a ocorrência de uma alteração nos pressupostos e na regra de reconhecimento.

Note-se que a reação da população pode não ser imediata ao surgimento de uma nova regra de reconhecimento no seio da prática dos officials ou mesmo ser completa, envolvendo apenas parte da população. Como Hart ([1961] 2009, pp. 78 e 152) indica, é possível a existência de estágios intermediários entre os casos centrais e os patológicos do sistema jurídico. O importante é considerar que há limites externos à prática de reconhecimento pelos officials, um limite que se encontra na própria atividade de reconhecimento pelo povo. Tanto o é que “quando a reação popular às prescrições do regime se tornam hostis e desobedientes, é recorrente na história que as camadas mais baixas dos agentes públicos percam a dedicação ao sistema e este rapidamente se desintegre” (Hughes, 1960, p. 1022). Nesses casos, somente os líderes dos officials não conseguem manter o suporte necessário à sobrevivência do sistema. Isso demonstra duas coisas: em primeiro lugar, que o grupo relevante sempre envolve o povo, que o "fiel da balança” é sempre o povo, de cuja adesão (ainda que manifestada de forma não ativamente participativa) depende a continuidade do sistema jurídico; e que o conteúdo da regra de reconhecimento última aponta para as fundações do ordenamento jurídico em questão. Esta última questão será abordada no próximo tópico

\section{4} Por uma nova compreensão do grupo reconhecedor relevante

Derrubadas as objeções à inclusão do povo no grupo reconhecedor relevante, é preciso oferecer uma concepção da regra de reconhecimento que seja 
compatível com a estrutura geral do positivismo jurídico e que não seja vulnerável aos problemas anteriormente expostos (da circularidade e da normatividade). Propõe-se uma visão que seja aceitável não somente sob o foco da teoria analítica do direito, mas que tenha um potencial explicativo para uma visão do direito como ele é praticado, ou seja, como ele se manifesta nas sociedades (Galligan, 2007, pp.121-122).

Gardner (2012, p. 78) afirma que a tese central do positivismo jurídico - a única compartilhada por todos os positivistas clássicos e contemporâneos - é a de que em qualquer sistema jurídico uma norma é válida como norma daquele sistema somente em virtude do fato de que em um momento e lugar relevantes agentes relevantes se engajaram de um modo relevante com aquele material normativo. Afirmou-se no tópico anterior que o modo relevante como ocorre esta interação com o material normativo não exige um conhecimento detalhado das tecnicidades jurídicas, e que os conceitos que se referem a esta relação ('aceitação', 'ponto de vista interno') devem ser tomados em seu valor de face. O que se quer argumentar aqui é que os agentes relevantes não são apenas os juízes ou apenas os officials, mas necessariamente também os cidadãos comuns, o povo.

Não se pretende fazer "teoria do direito democrática” (democratic jurisprudence), um tipo particular de teoria do direito que cuide apenas de democracias (Waldron, 2009a, p.679). Também não são atribuídas “aspirações democráticas” para o direito (Waldron, 2009a, p. 694). A visão aqui oferecida deve fazer sentido tanto em uma monarquia absolutista, uma ditadura, ou uma democracia constitucional. Por óbvio, a visão aqui avançada dá espaço aos cidadãos comuns nas fundações do direito, mas isso não significa dizer que é uma visão conceitualmente comprometida com valores democráticos, ou que ingenuamente negue que o direito pode ser usado para fins moral e politicamente condenáveis, como insistem em alertar Hart ([1961] 2009, p. 151) e Waldron (1999, p. 186).

Afirma-se que o povo é corresponsável pela prática de reconhecimento fundamental do direito, e que esta é relativa ao arranjo das instituições de poder inerente (Gardner, 2011, p. 173) e às suas limitações, mas não exclusiva a elas. A prática de reconhecimento diz respeito ao “conjunto de decisões políticas logicamente antecedentes ao direito”, que determinam seu conteúdo (Schauer 1993, p. 815). 
Mas o que se quer dizer com “conjunto de decisões políticas”? A resposta mais óbvia seria olhar para a Constituição. Entretanto, como já foi mencionado, a regra de reconhecimento não se confunde com a constituição, mas com as práticas que são expressas quando ela é aplicada, pois a própria questão da existência da constituição é uma questão respondida pela regra de reconhecimento (Green, 1996, p.1706). Nas palavras de MacCormick (2007, p.287):

O que faz as constituições funcionarem, quando elas funcionam? Obviamente, o que as faz funcionar é a vontade do povo que concebe a constituição para ser sua constituição, quando há um número suficiente de pessoas, suficicientemente de acordo (apesar de nunca unanimamente) a respeito de suas fundações ideológicas. O que eles acordam, articulada ou tacitamente, é uma norma comum que indica que eles devem respeitar a constituição assim fundada, e que qualquer pessoa pretendendo exercer poderes públicos deve fazê-lo apenas nos termos permitidos pela constituição. Consciência de tal norma (não necessariamente explícita ou tida nos mesmos termos por todos os participantes) leva a um costume (como a formação espontânea de uma fila). O costume pode ser formulado em termos como: ' todos no Estado S devem cooperar para garantir as funções estatais nos termos da constituição $C$ de acordo com os princípios estabelecidos', e isso pode muito bem ser chamado de uma norma fundamental.

Assim, é preciso compreender que a regra de reconhecimento aponta para questões como a forma constitucional (escrita ou não escrita em um ou um conjunto de textos canônicos), a possibilidade de sua alteração, as instituições de poder inerente (a distribuição dos poderes Executivo, Legislativo e Judiciário (Gardner, 2011, p. 171)), o seu relacionamento e a forma de limitação de tais poderes. São esses aspectos fundamentais do arranjo político-jurídico de uma sociedade que permitem diferenciar os gêneros e as famílias dos sistemas jurídicos e as consequentes diferentes formas de exercício do poder institucionalizado.

Apesar deste conteúdo mínimo, há casos em que a regra de reconhecimento incorpora outros fatores peculiares ao caso local. Por exemplo, no direito soviético a propriedade estatal dos bens de capital figurava como peça chave; em alguns países islâmicos, a base religiosa do direito é também inserida na regra mestra; nos Estados Unidos da América, a forma federativa certamente faz parte da regra última, interferindo inclusive no seu critério supremo apontando para cláusula constitucional entrincheirada que garante igual representação dos estados no Senado (Greenwalt [1987] 2009, p. 17).

A intensidade que esses fatores - tanto essenciais quanto os inessenciais são aceitos na sociedade é variável, mas rejeita-se aqui a hipótese de uma maioria 
da população completamente ignorante de todos esses aspectos da vida pública. Uma população completa de “ovelhas” absolutamente ignorantes é tão ou mais ficcional que uma população completa de cidadãos politicamente engajados e experts em direito constitucional. É possível que um fazendeiro do Wyoming não saiba exatamente os critérios de repartição de receitas na federação, ou da função do Senado Federal, ou até se Porto Rico é um estado americano, mas ele certamente sabe que o seu país é dividido em unidades administrativas chamadas 'estados'. Em Estados modernos, com regras de reconhecimento complexas que incorporem questões tormentosas como o peso da linguagem ordinária na interpretação dos textos jurídicos, a existência e vinculatividade de precedentes, a força normativa do Preâmbulo constitucional, entre tantas outras decisões políticas fundamentais que dão o contorno do sistema jurídico, pode ser que apenas uma pequena parcela da população - alguns cidadãos mais engajados politicamente, juristas e a imprensa, por exemplo - detenha conhecimentos técnicos mínimos a tal respeito. Como visto anteriormente (e o tema será retomado em breve), não é necessário expertise jurídica para aceitar a regra de reconhecimento. De todo modo, a possibilidade conceitual de uma população inteira de cidadãos acéfalos ou ignorantes deve ser ela mesma ignorada.

Parte-se da “inevitável dependência do direito do ambiente não jurídico em que existe”, da importância das compreensões e compromissos pré-jurídicos que fazem o direito possível (Alexander e Schauer, 2009, p. 192). A regra de reconhecimento não está “atrás” deste contexto social do fenômeno jurídico, como pretende Galligan (2007, p.87); ela conforma, é parte deste próprio cenário (Struchiner, 2005, p. 76). É neste pano de fundo que ela se desenvolve como como fato político (Schauer, 1995, pp.151-152), como prática social, padrão de comportamento visto na sociedade em aceitar certos critérios do que conta como direito e o que não conta como direito. É a partir desta compreensão que faz sentido afirmar que a regra de reconhecimento é uma prática social normativa que está situada logicamente antes das normas jurídicas mais básicas, as normas constitucionais (sejam elas escritas ou não), que conformam as instituições político-jurídicas mais básicas. Ela se expressa na disposição de tratar tais normas como direito válido (Waldron, 2006, p. 1713) e de formar o sistema jurídico a partir destas normas jurídico-constitucionais. Aqui fica claro o caráter constitutivo da regra de reconhecimento; nas palavras de Marmor (2009, p.165), “o papel 
básico das regras de reconhecimento é constituir as instituições relevantes. As regras fundamentais de reconhecimento são regras constitutivas”.

Para os propósitos da proposta aqui avançada, a regra de reconhecimento é convencional no sentido empregado por Hart, e não como uma convenção coordenativa de Lewis (Himma, 2009, p. 97) ou no sentido específico de convenção constitutiva de Marmor. Ela é uma regra convencional na medida e no sentido atribuído por Hart ([1961] 2009, p. 330) de que a aceitação pelo grupo está entre as razões que levam os membros individuais do grupo a aceitar a regra. A convencionalidade da regra é uma de suas propriedades, uma de suas características, mas aqui não será adotada uma visão que reduza a regra a uma convenção no sentido que filósofos como Lewis e Marmor atribuem ao termo. Ela é, portanto, uma regra constitutiva convencional.

Mas como dar conta das diferenças evidentes nas práticas de cidadãos e autoridades públicas? Certamente, o papel e a posição dos cidadãos comuns e o papel e a posição das autoridades públicas não são os mesmos na prática de reconhecimento da regra última. Se assim fosse, o problema da circularidade não seria resolvido. É preciso, pois, pensar na aceitação da população como um fato social logicamente anterior ao dos officials, apesar da aceitação destes ocorrer em um modo (Galligan, 2007, p. 95) mais intenso que a aceitação daqueles. Os officials precisam ser reconhecidos como tal por meio das regras secundárias que lhes confiram poderes. Assim, é primeiro preciso haver aceitação da sociedade da regra que estabelece o arranjo político-jurídico em que existam regras secundárias que permitam a afirmação de que officials são officials. Tome-se em conta o afirmado por Lagerspetz (1995, p. 160):

Pessoas comuns usualmente não conhecem o conteúdo da constituição ou das regras essenciais de direito público. De fato, o direito moderno é por demais complexo para ser compreendido exceto por especialistas. Mas pessoas ordinárias podem de um modo geral reconhecer certas pessoas como autoridades (como policiais, juízes, Membros do Parlamento ou Chefes de Estado). Eles têm uma concepção do que essas pessoas podem ou não podem fazer, e quando e até onde devem ser obedecidas.

O filósofo finlandês dá uma pista do caminho a seguir, mas se perde ao afirmar, parágrafos depois, que a autoridade (legal) de uma convenção constitucional em um país recém formado ou de um monarca usurpador advém de um fiat, e não do reconhecimento pela própria sociedade. Por óbvio, a convenção constitucional e o usurpador podem instaurar um período de terror, eliminando 
qualquer adversário político e qualquer resistência popular, impondo suas prescrições jurídicas por meio de um aparato de sequazes dispostos a levar a coerção às últimas consequências. Como visto na análise do problema da normatividade, tais sistemas jurídicos (que muito lembram o sistema jurídico mínimo de Hart) sofrem dos mesmos problemas que o soberano austiniano, sendo comparáveis a uma quadrilha ${ }^{58}$ e portanto casos patológicos, não centrais.

Adler (2006, p.766) reforça a ideia aqui em construção ao afirmar que sistemas jurídicos dependem da intencionalidade coletiva de grupos de indivíduos, que coletivamente reconhecem certas entidades (que existem somente em virtude deste reconhecimento) e fazem sua parte na criação e manutenção de um sistema jurídico. Aduz, também, que regras constitutivas podem ser praticadas por diversos grupos de pessoas - cidadãos ou officials - que podem agir conjuntamente para desenvolver um sistema jurídico, não havendo nenhum aspecto teórico que imponha um único grupo reconhecedor. A despeito da possibilidade teórica (contingente) desses diferentes grupos instanciarem diferentes regras dentro de um mesmo arcabouço - o que é o cerne da proposta de Adler por uma concepção “grupo-relativa” -, o foco aqui é na possibilidade de que os grupos convirjam na sua prática reconhecedora ${ }^{59}$.

Tem-se, então, diferentes grupos aceitando uma mesma regra, convergindo nesta prática, ainda que de modos e diante de situações diferentes. Isso contribui para explicar como as decisões dos officials, inclusive e especialmente dos juízes, são dependentes da aceitação da população de uma regra que lhes confira o poder para terem o efeito que lhes é característico. Se, por exemplo, a vasta maioria dos cidadãos parar de tratar como vinculantes as decisões das cortes baseadas em uma regra putativa de reconhecimento, tais decisões simplesmente não estariam funcionando do modo como o direito deve funcionar. Assim, mesmo aqueles autores que colocam a primazia da prática de reconhecimento nas cortes deveriam considerar que a adesão da sociedade à regra de reconhecimento tem um papel

58 Se toda forma de intervenção e coação estatal é ilegítima - visão representada pelo mote libetário "Não roube! O governo detesta concorrência!” ou pela afirmação de Murray Rothbard em "The Ethics of Liberty” de que o Estado é uma gangue de ladrões ampliada (a gang of thieves writ large) - é outra questão que não cabe aqui adentrar.

${ }^{59}$ Com isso quer-se apenas dizer que a concepção grupo-relativa avançada por Adler não pode sustentar uma teoria geral, sendo - como o próprio autor afirma em seu trabalho - mais uma tentativa de explicar o direito norte-americano. 
“mediato", funcionando como um limite factual externo ao conteúdo da regra de reconhecimento (Himma, 2003, p. 155, nota 8).

Mas não é só isso. Se, por exemplo, o povo brasileiro passar a aceitar a anteriormente mencionada Constituição Noelina como documento que governa as instituições jurídico-políticas no território brasileiro, e se as autoridades públicas por ela constituídas também levarem o documento a sério, aplicando suas provisões ao invés das provisões da “Constituição Cidadã”, então a Carta Noelina será a Constituição brasileira, enquanto que o documento datado de 5 de outubro de 1988 passará a ser apenas um punhado de folhas de papel de valor histórico mas juridicamente irrelevante (Schauer, 1995, p.153). Como explicado na abordagem do problema da normatividade, é o povo o "fiel da balança”, cuja aquiescência é necessária para o sucesso do direito (Galligan e Versteeg, 2013, p. 25) e que indica, em última instância, qual regra de reconhecimento prevalecerá de modo não patológico em determinado terriório.

Isso implica em reconhecer que a aceitação popular ocorre em um nível mais profundo que a dos agentes públicos. As práticas da população e dos agentes públicos são sobrepostas: sem as primeiras o sistema jurídico (mínimo) sofre com os problemas da circularidade e da normatividade, e representa um caso patológico que não sobrevive (Galligan, 2007, p.130); sem a prática dos officials, contudo, um sistema jurídico completo e moderno não tem operabilidade ${ }^{60}$.

Mas como explicar a aceitação da população diante do fato inquestionável que indivíduos leigos não possuem conhecimento jurídico? Retomando a questão iniciada no tópico anterior, que tipo ou nível de aceitação é este praticado pelo povo - ou, pelo menos, por parte considerável do povo ${ }^{61}$ ?

Parece ser o caso de uma aceitação indireta, mediata. Ainda que os cidadãos não tenham conhecimento dos detalhes técnicos a respeito da interpretação e aplicação da constituição e do direito como um todo, eles “confiam em outros corpos - os profissionais do direito, agentes políticos eleitos,

${ }^{60}$ É o que também afirma Hardin, (2013, pp. 59-60), entretanto focando, com usa teoria convencional dual, de matriz Humeana, no aspecto coordenativo do surgimento do direito e das instituições estatais, calcada na aquiescência da população em ambas as convenções.

${ }^{61}$ Não se pode esquecer que há cada vez mais uma participação popular na esfera pública, que pode ser explicada por uma gama de posturas, desde um patriotismo típico dos séculos passados até um engajamento em questões específicas como visto nos movimentos de direitos humanos (Adler, 2006, pp.773-774). Essa participação, contudo, não é conceitualmente necessária e não pode fundamentar uma teoria geral e descritiva. 
a imprensa - para informá-los a respeito de algum golpe constitucional” (Alexander e Schauer, 2009, pp.86-87). Eles parecem manter uma atitude proativa em momentos pontuais que afloram de um estado contínuo de vigilância. Trata-se de uma “disposição de longo termo” (Shiner, 1992, p. 177) com episódios esporáidicos de mobilização aguda $^{62}$ - quando surgem questões institucionais relevantes. Nos tempos de normalidade, o que se percebe é uma aquiescência uma aceitação tácita do estado de coisas, do arranjo institucional - no sentido em que as pessoas convencionalmente tomam o sistema e o arranjo constitucional como autoritativo (Galligan e Versteeg, 2013, p. 26).

Cabe, por fim, mostrar como a proposta ora avançada supera os problemas conceituais que afligem a posição canônica, a começar pelo problema da circularidade. Nas palavras de Greenwalt ([1987] 2009, p. 4 nota 6) “a quebra no círculo ocorre quando se olha para a população como um todo para ver quem é reconhecido como autoridade pública”. Já Lagerspetz (1995, p. 159) parte do fato de que a autoridade política é fato social e "baseado no reconhecimento geral da população relevante”. Burazin (2014, p. 9) aduz que:

A intencionalidade coletiva necessária para impor o status de autoridade legal é expressa por meio do reconhecimento coletivo de um grupo como possuindo um status especial. Aqueles reconhecendo coletivamente o grupo como autoridades legais são os cidadãos ordinários, bem como agentes públicos em potencial.

Isto porque parte-se do povo como um fato, um dado político-sociológico, identificável independente de regras jurídicas. Neste sentido, adota-se posição diversa da de Green (1996, p.1700), para quem falar em uma determinada população, como “o povo da Califórnia” é em si um conceito jurídico. Segundo afirma, “a irrelevância da atitude das pessoas que vivem em Tijuana é algo que precisa ser explicado e não suposto pela teoria do direito”.

Tome-se o exemplo dado pelo autor inglês: qual a diferença relevante entre as pessoas que estão em San Diego e as que estão em no México? O que faz de um agrupamento de pessoas 'norte-americanos' e de outro agrupamento ‘mexicanos’? É o direito de cada um destes países - direito este que só é

${ }^{62}$ Um exemplo é o descrito por Bruce Ackerman (We The People: Foundations. Cambridge: Harvard University Press, 1991) e a sua teoria da "democracia dualista”, mostrando a alternância entre períodos de normalidade política e “momentos constitucionais”, em que há uma notável mobilização - impossível de ser sustentada indefinidamente - do povo norte-americano. Nos períodos de normalidade política, entretanto, o povo parece confiar em seus representantes políticos para a criação das leis e manutenção do sistema jurídico. 
logicamente possível após a prática de reconhecimento e aceitação das regras secundárias - ou é o próprio reconhecimento do grupo, ou melhor, um reconhecimento de grupo? Parece ser o caso de lançar mão de teorias sociológicas para explicar este fenômeno que, repita-se, não é jurídico. O espaço e escopo deste trabalho, entretanto, não permitem tal abordagem, e fica apenas a menção à rejeição da abordagem de Green: não acredita-se ser tarefa da teoria do direito explicar um fenômeno eminentemente sociológico e político.

Por fim, a solução para o problema da normatividade. Com a inclusão do povo no grupo reconhecedor relevante, é possível falar que a população como um todo está no escopo da obrigação gerada pela própria regra de reconhecimento de seguir o direito por ela identificado, e não mais meramente obrigada - coagida - a seguir as prescrições jurídicas. Como visto anteriormente, a existência de sujeitos ou grupos (minoritários) desviantes não invalida a conclusão de que uma norma existe em determinado grupo (Hart [1961] 2009, p. 75).

Afirmar que o povo toma parte na prática social de reconhecimento (ou seja, que o povo aceita a regra de reconhecimento última) significa afirmar que o escopo de tal regra abrangeria a sociedade como um todo e não somente os indivíduos identificados como officials, gerando a obrigação geral de obediência ao direito e revelando o caráter normativo do direito derivado da regra última. Mais que isso, a inclusão do povo no grupo reconhecedor revela um caso central de sistema jurídico (Shiner, 1992, p. 182):

Se um sistema jurídico estável e funcional existe, e se o sistema não é coercivo, segue-se então que o sistema deve ser aceito. E se um sistema normativo não é um sistema jurídico a não ser que seja não coercivo, então um sistema normativo não é um sistema jurídico a não ser que seja aceito. Apontar para um sistema não coercivo e eficaz é apontar para uma entidade que é paradigmaticamente um sistema jurídico, não meramente um caso saudável de algo que seria um sistema jurídico mesmo sendo coercivo e patológico

Há, portanto, duas razões para chamar o sistema jurídico mínimo de Hart de um caso patológico. A primeira, mais forte, se refere à incapacidade de este sistema evitar a circularidade e gerar obrigação na população de seguir o direito: o problema da normatividade, aqui aludido. O segundo motivo - mais fraco - reside no fato de que são sistemas fadados ao fracasso, posto que "contém as sementes da sua própria futura rejeição” (McBride, 1965, p. 394). Esta “doença”, por si só, não daria razão para considerar o sistema jurídico mínimo um caso fora da zona central do respectivo conceito. Contudo, soma-se ao problema da normatividade 
para mostrar que Hart também pecou, pagando um preço alto pela uniformidade de sua teoria. Nas palavras de Galligan (2007, p.128):

Na preocupação de definir uma descrição ampla o suficiente para cobrir todos os sistemas jurídicos internos (municipal), dos bons aos maus até os intoleráveis, Hart teve que dar conta de sistemas jurídicos sustentados com o menor dos suportes da população. (...) Contudo, por mais convincente que possa ser para a teoria do direito, há diversos motivos para considerá-lo, e a distinção feita entre agentes públicos e o povo, como não persuasivos para o direito-e-sociedade. Em primeiro lugar, é difícil pensar em exemplos históricos de sistemas em que os cidadãos meramente obedeceram e os agentes públicos aceitaram. Quanto mais aprendemos sobre os sistemas considerados mais repugnantes dos tempos recentes, a Alemanha de Hitler, a União Soviética de Stalin, a China de Mao, mais claro fica que eles contavam não apenas com obediência mas com apoio positivo de grandes setores da população. Se exemplos de regimes que careciam de apoio popular podem ser achados, as chances são de terem tido vida curta, fazendo deles casos patológicos e não casos normais de um sistema jurídico.

Em resumo: o grupo reconhecedor relevante não envolve apenas os juízes, nem apenas os officials, mas toda a população. Isso não significa, contudo, que todos os subgrupos dentro deste conjunto devam exercer exatamente a mesma prática. Algumas tarefas são exclusivas de certos grupos, por definição de suas próprias funções, pelo fato que cada grupo lida com o material jurídico de uma forma diferente. Mas isto não implica que diferentes grupos aceitem diferentes regras últimas de reconhecimento; são atividades que estão de um modo ou outro relacionadas com uma mesma regra - ou melhor, contidas na mesma regra - que é aceita por toda a sociedade. Seguindo a Atienza e Ruiz Manero (1998, p. 150), Struchiner (2005, pp.75-76) afirma:

Os teóricos do direito também contribuem na construção e identificação da regra de reconhecimento. Assim, quando constitucionalistas sustentam em seus livros a importância da força normativa da Constituição, e os seus escritos influenciam uma mudança de perspectiva na leitura da Carta Maior, fazendo com que ela deixe de ser considerada uma carta política, para efetivamente ganhar um peso jurídico intrínseco, então eles estão moldando e solidificando a aceitação de uma determinada regra de reconhecimento. A contribuição dos operadores do direito, principalmente dos advogados, consiste na formação de expectativas: se eles nãot ivessem uma expectativa de que a mesma regra de reconhecimento seria internalizada pelos juízes, órgãos administrativos e legisladores, a sua própria função se tornaria obsoleta. (...) O advogado pressupõe a existência de uma regra dereconhecimento comum, compartilhada por todos que atuam na esfera jurídica, para poder desenhar os comportamentos possíveis de acordo com o direito (...). Finalmente, os cidadãos também participam ativamente da construção e manutenção da regra de reconhecimento. Seria impossível o uso do direito como um mecanismo de previsão acerca das conseqüências das próprias ações se não houvesse, mais uma vez, uma certa expectativa de que todos, pelo menos na grande maioria dos casos, concordassem ao menos sobre onde começar a procurar e buscar o que conta como direito. Conforme notou Schauer, se a opinião pública conta de alguma forma para a atuação dos juízes e legisladores, 
então os cidadãos também fazem parte do projeto arquitetônico da formação da regra de reconhecimento última.

Divergências podem ocorrer nesta prática de reconhecimento, e para que se identifique uma convergência não é necessário estabelecer uma regra numérica ou um limite estatístico a partir do qual considera-se ocorrida a aceitação. Como afirma Greenwalt ([1987] 2009, p.40), um standard pode prevalecer mesmo sem ser compartilhado por uma maioria.

Essa parece ser a lição possível de ser extraída da concepção grupo relativa (Adler, 2006) e de autores como Galligan (2007, p. 95), que falam na diferença das práticas que compõem a prática social da regra de reconhecimento. Cada grupo está envolvido com uma prática, desenvolve atividades que estão relacionadas a um ou outro aspecto da regra. Havendo diferentes formas e modos de interação com o direito, é também neste sentido possível falar em diferentes níveis de aceitação pelos diferentes grupos sociais e institucionais (Galligan, 2007, p. 94), o que justifica a afirmação de que a população em geral também participa desta prática de reconhecimento, ainda que em uma intensidade inegavelmente menor que a de grupos como juízes e legisladores e até mesmo confiando nestes e em outros grupos (como dos juristas, dos políticos) para mediar esta interação (Alexander e Schauer, 2009, pp.86-87).

Caso um grupo passe a atuar de modo irremediavelmente divergente da prática aceita por toda a sociedade, uma crise institucional será deflagrada e a coesão e unidade ordenamento jurídico passarão a ser questionadas. Nesse caso, parece ser possível falar que o ordenamento caminha para um estado patológico. 


\section{A regra de reconhecimento do direito brasileiro}

Como regra social, os elementos da regra de reconhecimento são empiricamente observáveis (Himma, 2009, p. 99). Neste último capítulo pretendese oferecer um mapeamento dos contornos da regra de reconhecimento última do direito brasileiro na atualidade. Não se pretende buscar uma formulação definitiva, mas trabalhar os principais aspectos que sobressaem na prática de reconhecimento do direito no Brasil. Parte-se, claro, de algumas noções anteriormente apresentadas, em especial quanto à inclusão do povo no grupo reconhecedor relevante.

Assim, em breve recapitulação dos aspectos conceituais que aqui são adotados como base para aplicar a teoria ao direito brasileiro, pode-se afirmar que a regra de reconhecimento é uma regra costumeira (costume in pays e não in foro) constitutiva que identifica certos institutos como critérios de validade e, com seu caráter regulativo, impõe a obrigação de seguir o direito reconhecido mediante tais critérios. Ela é constituída por três elementos:

a) uma base factual (a prática social convergente do grupo);

b) um conteúdo apontando os critérios de validade do direito de determinada sociedade;

c) caráter normativo (impondo a obrigação de seguir o direito reconhecido com o uso dos critérios apontados)

A inclusão de um elemento normativo é necessária, mas ele não pode ser confundido com o conteúdo da regra, pois os critérios em si são meramente descritivos, carecendo de normatividade (Himma, 2009, p. 98). A questão principal, entretanto, é separar a base factual da regra de reconhecimento do seu conteúdo.

Como será visto adiante, a regra de reconhecimento última não é a Constituição, mas seu conteúdo pode apontar para critérios que tomam formas constitucionais, sejam elas manifestadas em textos constitucionais ou em costumes constitucionais. Não se pode pensar que a regra de reconhecimento se confunde com normas materialmente importantes (Atienza e Ruiz Manero, 1998, p. 146), até mesmo pelo fato de que, como anteriormente explicado, ela em geral sequer é expressamente formulada. Ela é uma prática logicamente préconstitucional, o predicado para a validade (Schauer, 1995, p.152) da proposição 
de que o documento promulgado em 5 de outubro de 1988 é a Constituição da República Federativa do Brasil. Essa regra última irá, então, apontar para os critérios últimos de validade do direito, criando uma ordem hierarquizada (Greenwalt, [1987] 2009, p.8), em que a Constituição Federal prevalece sobre toda a legislação infraconstitucional, que a legislação prevalece sobre os costumes jurídicos, os atos normativos primários prevalecem sobre os atos normativos secundários $^{63}$ etc.

Ela também irá identificar as regras secundárias de adjudicação, alteração e regras de reconhecimento derivadas. É nesse “segundo nível” de identificação do direito válido que, por exemplo, as disputas a respeito da interpretação constitucional ocorrem. Como dito, a Constituição não é nem contém regras de reconhecimento últimas, pois elas (e todas as suas cláusulas) dependem deste fundamento pré-constitucional para sua validade. A regra de reconhecimento se localiza, fundamentalmente, na disposição convergente na sociedade em aceitar (com muitas qualificações) a Constituição de 1988 como norma jurídica suprema. Afirmar que a regra de reconhecimento advém de práticas de atores não judiciais e que não está contida na Constituição judicializada requer enxergar além do véu colocado pelo “caso de amor” da comunidade jurídica com a sua constituição (Dorf, 2009, p. 74).

O mapeamento da regra última será iniciado no próximo tópico com a análise do papel da Constituição na regra de reconhecimento (4.1), seguido de estudos sobre as cláusulas pétreas e sua relação com o critério supremo (4.2); sobre a regra de adjudicação do direito brasileiro e aspectos da regra de reconhecimento envolvendo a competência do Supremo Tribunal Federal, a supremacia judicial (e seus limites), os critérios interpretativos utilizados na aplicação do direito e a atividade normativa nas cortes (4.3); a regra de alteração do direito brasileiro, englobando as alterações formais e informais à Constituição, além dos processos de criação normativa (4.4); a incorporação de fatores morais por meio dos princípios como critério de validade no direito brasileiro, em

\footnotetext{
${ }^{63}$ Atos ou tipos normativos primários (ou autônomos), categoria do direito constitucional, não podem ser confundidos com a categoria de regras primárias da teoria do direito. Aqueles são todas as normas derivadas diretamente da Constituição Federal e, portanto, sujeitas à fiscalização direta de constitucionalidade. Com eles contrastam atos normativos secundários, que derivam sua validade dos atos normativos primários e que, portanto, somente podem violar a Constituição de maneira indireta ou reflexa.
} 
especial nos direitos fundamentais, e a existência de limites à aplicação de tais princípios por meio de postulados interpretativos (4.5).

\section{1}

\section{A Constituição Federal de 1988 como ponto de partida}

Uma constituição é uma necessidade conceitual de todo e qualquer sistema jurídico (Gardner, 2011, p.162). Em todo ordenamento, há regras que especificam as instituições de governo e agentes públicos, determinam como interagem e como ocorre sua sucessão. Estas normas, que indicam o "modo como o poder político é organizado e dividido” (Gardner, 2011, p.169), e sem as quais um conjunto de normas jurídicas não pode ser considerado um sistema jurídico, são normas constitucionais (Gardner, 2011, p.162), independente da forma como sejam veiculadas - em um único texto canônico, em um conjunto de textos produzidos ao longo dos séculos ou em costumes (Sgarbi, 2007, pp.348-349; Gardner, 2011, p.164). Seu status não é determinado pela forma como são criadas, mas como são recebidas pelo grupo reconhecedor relevante da comunidade política respectiva; são dependentes, portanto, da regra - não escrita - de reconhecimento (Gardner, 2011, p.167), fundada na convergência de expectativas da sociedade, incluindo tanto os agentes públicos quanto os cidadãos (MacCormick, 2008, p.141).

Mas isso não significa que nos casos em que há uma Constituição escrita (contendo aspectos da constituição) o texto não faça diferença. No Brasil (assim como nos Estados Unidos) parece haver uma “convergência institucional” apoiada no texto reconhecido como a Constituição da República Federativa do Brasil, que faz com que as concepções e expectativas dos diferentes subgrupos da comunidade reconhecedora partam do mesmo conjunto de instituições (“Congresso”, "Supremo Tribunal Federal”, "Presidência”, etc.) criado pelo texto da Constituição (Adler, 2006, p. 767).

Portanto, qualquer tentativa de estabelecer a regra de reconhecimento no direito brasileiro deve olhar inicialmente Constituição Federal; afinal, ela é tratada como o conjunto de normas jurídicas superiores no território brasileiro. Algumas formulações iniciais são candidatas a descrever a relação da 
Constituição com a regra de reconhecimento - em uma adaptação do proposto por Greenwalt, ([1987] 2009, p.16):

1) Toda ou parte da regra de reconhecimento é: o próprio texto da Constituição Federal de 5 de outubro de 1988, com todas suas alterações;

2) Toda ou parte da regra de reconhecimento é: tudo que a Constituição contiver que não tenha sido promulgado com base em outra parte da Constituição (ou seja, com a exclusão de todas as emendas constitucionais e dos tratados internacionais de direitos humanos recepcionados com status de emenda constitucional, de acordo com o artigo $5^{\circ}$, $\S 3^{\circ}$, inserido pela Emenda Constitucional 45/04);

3) Toda ou parte da regra de reconhecimento é: a Emenda Constitucional $n^{\circ}$ 26 de 27 de novembro de 1985, que convocou a Assembleia Nacional Constituinte e tudo que tiver sido adotado de acordo com ela.

Como visto anteriormente, a Constituição não tem validade em si mesma, ainda que contivesse dispositivo normativo ${ }^{64}$ que a indicasse como norma jurídica superior no Brasil. Excluir as emendas constitucionais (que parecem dever seu status de direito válido às cláusulas constitucionais que disciplinam o processo de alteração constitucional) não resolve o problema. Assim, as proposições 1 e 2, que apontam para o texto integral atual ou para o texto original da Constituição não parecem prosperar: a regra de reconhecimento não é a Constituição.

Um constitucionalista que tenha interpretado incorretamente a afirmação que a regra de reconhecimento se funda em algo anterior à Constituição poderia procurar fundamentação de validade no próprio processo que deu origem ao texto constitucional. Afirmaria, assim, que sua validade decorre de sua origem na Assembleia Nacional Constituinte - convocada pela Emenda Constitucional $n^{\circ} 26$, de 27 de novembro de 1985 (EC 26/85) -, de sua promulgação em 5 de outubro de 1988 de acordo com o disposto no artigo $3^{\circ}$ da referida Emenda ${ }^{65}$. Cabe, então, investigar a formulação 3, que identifica o fundamento jurídico de validade na transição constitucional entre o regime de 67/69 e o atual.

${ }^{64}$ Como é o caso do artigo VI da Constituição Americana, que a trata como "supreme law of the land". Afirmar que a Constituição é a norma suprema porque ela diz que é não é uma resposta satisfatória, como visto no início deste trabalho: trata-se de uma petição de princípio, pressupondo-se aquilo que se quer provar.

65 “A Constituição será promulgada depois da aprovação de seu texto, em dois turnos de discussão e votação, pela maioria absoluta dos Membros da Assembléia Nacional Constituinte.”. 
A situação brasileira pode ser comparada a outras, já estudadas por hartianos norte-americanos e espanhóis. Analisa-se aqui a possibilidade de o fundamento de validade das Constituições residir em proposições normativas que estabelecem formalmente as condições para sua aprovação, quer sejam fruto de uma ruptura formal com o sistema anterior (como no caso americano) quer sejam fruto de um continuum formal entre regimes jurídicos. Nos Estados Unidos da América, positivistas hartianos questionaram se a validade da Constituição não dependeria de sua cláusula de Rafiticação, o Artigo VII, que exigiu a ratificação de assembleias de nove dos treze estados para o estabelecimento da Constituição e a suplantação dos Artigos da Confederação. O caso espanhol, entretanto, é análogo ao brasileiro. A Lei para a Reforma Política ${ }^{66}$ foi o instrumento normativo que permitiu a transição do regime ditatorial do General Franco para a monarquia constitucional, que culminou na promulgação em 6 de dezembro de 1978 da atual Constituição Espanhola.

Duas são as possibilidades: a primeira considera que a regra de reconhecimento é a EC 26/85 (3A), e a segunda indica que a regra de reconhecimento identifica como direito válido tudo aquilo que for criado a partir da EC 26/85 (3B). A solução 3A sofre dos mesmos problemas de 1 e 2, pois não há nada na própria EC 26/85 que indique sua fonte de validade jurídica; seria necessário recorrer ao texto constitucional do regime militar (a Constituição de 1967 na redação dada pela Emenda Constitucional nº 1, de 1969, que suplantou integralmente o texto original), e assim sucessivamente. Esta regressão, que pode interessar ao constitucionalista pátrio de filiação kelseniana em busca da primeira constituição histórica ${ }^{67}$, não prospera para os fins do presente trabalho.

Apesar de dar conta do fato de que o status e a autoridade da EC 26/85 são externos a ela, e considerar que ela não é, mas descreve a regra de reconhecimento (Alexander e Schauer, 2009, p.180), afirmar, como em 3B, que a regra de reconhecimento aponta para estas formas jurídicas de transição é também

${ }^{66}$ A Lei 1/1977, de 4 de janeiro, aprovada em 18 de novembro de 1976 e submetida a referendo em 15 de dezembro de 1976.

${ }^{67}$ V. KELSEN, Hans. Teoria Geral do Direito e do Estado. 4a Edição. São Paulo: Martins Fontes, 2005, p. 168. O próprio Kelsen possui trabalho, como consultor, a respeito da Assembleia Nacional Constituinte de 1933/34 (in Revista Trimestral de Direito Público, nº 9, São Paulo: Malheiros, 1995, pp. 5-8, e sua influência no pensamento teórico-constitucional brasileiro não pode ser subestimada. 
incorreto, ao menos para uma formulação atual da regra de reconhecimento em todos os ordenamentos citados. Ainda que nos momentos de transição tais materiais normativos tenham sido importantes para validar a substituição dos regimes jurídicos - como no caso brasileiro, em que o poder constituinte originário se valeu da autodissolução da ordem anterior para realizar a nova obra constitucional (Mendes, Branco e Coelho, 2009, p. 235) -, nos dias de hoje não possuem mais relevância jurídica, não fazendo parte da regra de reconhecimento (Greenwalt, [1987] 2009, p.18; Atienza e Ruiz Manero, 1998, p. 147).

Mas por qual razão isso ocorre? Teria alguma relação com o fato que a Assembleia Nacional Constituinte seguiu todos os requisitos formais na feitura da Constituição, ou pelo fato de que a autoridade da Constituição Federal de 1988 resta na sua contínua e presente aceitação como norma jurídica suprema no direito brasileiro?

A primeira hipótese parece não se sustentar se for considerado que alguns dispositivos constitucionais não foram aprovados exatamente de acordo com o procedimento da EC 26/85: houve normas aprovadas só no segundo turno ou apenas na aprovação da redação final (Silva, 2014, p. 207). Ainda que se argumente que os desvios foram pequenos e não macularam o processo constituinte, o que aconteceria se fosse descoberto hoje um erro grave no processo constituinte? Suponha-se que as assinaturas no documento original foram forjadas, ou que os constituintes tenham sido subornados ou ameaçados de morte para aprovar o documento - amanhã a Constituição de 1988 seria tida como inválida? Certamente haveria uma comoção por parte da população brasileira, pessoas envolvidas seriam investigadas, carreiras políticas seriam manchadas e uma importante página da história política do povo brasileiro precisaria ser reescrita. Mas após quase trinta anos de aceitação e aplicação como o documento normativo hierarquicamente superior no direito brasileiro (e depois de tantos esforços da comunidade jurídica para fazer valer a sua força normativa como tal), parece impossível (ou ao menos extremamente improvável) conceber que o documento de 5 de outubro de 1988 possa ele também defenestrado da vida jurídica no Brasil por uma questão formal (por mais grave que fosse) em seu nascimento.

Pode-se até tentar alegar que durante a transição do regime militar para a democracia - e talvez até mesmo nos anos subsequentes à promulgação da 
Constituição Federal de 1988 - a norma de reconhecimento do direito brasileiro apontava para a EC 26/85 como peça chave nos critérios de validade jurídica, pois dela derivaria (como de fato derivou) um novo documento constitucional. Talvez tenha realmente sido este o caso, e uma confirmação desta hipótese demandaria uma investigação histórica e sociológica que não é do escopo do presente trabalho. Contudo, tal caracterização teria apenas significância histórica, pois já foi mostrado que o reconhecimento deve ser feito sempre no presente, e há boas razões para afirmar que a descrição mais apurada da prática atual de aceitação na comunidade jurídica brasileira indica que este processo não é mais diretamente relevante para a verificação do direito válido no Brasil - tal qual explicitado por Greenwalt ([1987] 2009, p.19) em relação ao artigo VII da Constituição Americana de 1787.

Mesmo em ordens jurídicas estáveis, o que conta como parte da regra de reconhecimento pode perder seu status ao longo do tempo e outros aspectos antes insignificantes podem ganhar importância. O período de alteração dos critérios últimos de reconhecimento pode ser nebuloso e confuso (Greenwalt, [1987] 2009, p.22), e podem ocorrer "incertezas profundas a respeito de onde a derivação termina e a aceitação começa em sistemas jurídicos operativos” (Greenwalt 1987] 2009, p.23). Se atualmente é correto afirmar que a Constituição Federal de 1988 ganhou autonomia própria, talvez seja possível identificar em algum momento entre sua promulgação e os dias de hoje o ponto em que seu status como norma jurídica superior deixou de ser derivado da EC 26/85 e passou a residir na aceitação do texto em si como tal. Alguns candidatos para este momento marcante podem ser o próprio dia 5 de outubro de 1988 (que, contudo, parece improvável); o dia 29 de dezembro de 1992, no qual o então Presidente Fernando Collor de Mello renunciou em meio a um processo de impeachment, prevalecendo a institucionalidade constitucional mesmo diante de uma grave crise política sem que se tenha cogitado da possibilidade de qualquer solução fora da legalidade constitucional; o dia 21 de abril de 1993, com a realização do plebiscito inicialmente previsto no artigo $2^{0}$ do Ato das Disposições Constitucionais Transitórias (ADCT); ou até mesmo o momento (caso seja possível precisá-lo) em 
que a chamada "doutrina brasileira da efetividade" ${ }^{68}$ prevaleceu e o Supremo Tribunal Federal passou a dar efetividade plena às normas constitucionais veiculadoras de direitos sociais. A definição deste marco, entretanto, é também tarefa da história do direito constitucional brasileiro, e não está inserida no escopo do presente trabalho.

As emendas constitucionais também estão sujeitas ao mesmo tipo de processo; contudo, ao contrário de suas similares norte-americanas, que parecem ter ganhado autonomia frente à cláusula constitucional que institui o procedimento de emendas (Greenwalt, [1987] 2009, p.28; Dorf, 2009, p. 91), no Brasil não parece ser este o caso. Alguns motivos poderiam ser levantados, como o fato de serem muitas as emendas (precisamente 84, até o fechamento deste trabalho) e ter havido uma "banalização" da alteração constitucional, ou de seu conteúdo não ser tão expressivo ou politicamente sensível quanto o das emendas norte-americanas (como o Bill of Rights - as dez primeiras emendas - ou as emendas do período da Reconstrução (pós guerra civil), que acabaram com a escravidão e garantiram cidadania a todas as pessoas nascidas em solo americano ou naturalizadas). De todo modo, o importante é notar que aqui as emendas parecem ainda derivar seu status jurídico da sua aprovação de acordo com a forma estabelecida no texto constitucional, mais precisamente com o artigo 60, que será objeto de estudo aprofundado no próximo tópico.

Por ora, cabe retomar a tentativa de apresentar uma formulação inicial para a regra de reconhecimento do direito brasileiro. Se as hipóteses que confundiam regra última e textos normativos merecem ser abandonadas, é preciso retomar as lições apresentadas ao longo do presente estudo e explorar um novo caminho, a partir da ideia de que a regra de reconhecimento representa a disposição $d a$ comunidade político-jurídica em aceitar a Constituição de 1988 como documento jurídico hierarquicamente superior no direito brasileiro:

4) É válido como direito o próprio texto da Constituição da República Federativa do Brasil, de 5 de outubro de 1988, com todas suas emendas, bem como todo o direito com ele compatível

${ }^{68}$ Para mais sobre a doutrina brasileira da efetividade, ver BARROSO, Luís Roberto. "A doutrina brasileira da efetividade.” In Temas de direito constitucional, tomo III. Rio de Janeiro: Renovar, 2005. 
Este parece ser um bom ponto de partida, mas merece diversas qualificações que dizem respeito às decisões político-jurídicas fundamentais que determinam os contornos do direito pátrio (Schauer 1993, p. 815).

A primeira delas se refere à possibilidade de normas constitucionais inconstitucionais ${ }^{69}$. Quanto ao texto original, obra do poder constituinte originário, adota-se no Brasil a postura de que deve ser concebido em sua unidade e coerência, não havendo portanto que se falar em hierarquia entre normas constitucionais originárias ou conflitos reais entre elas (Mendes, Branco e Coelho, 2009, p. 135). Também não se admite tradicionalmente ${ }^{70}$ limitação material jurídica ao poder constituinte originário (Mendes, Branco e Coelho, 2009, p. 232; Ferreira Filho, 2014, p. 95). Portanto, não há no Brasil o fenômeno da inconstitucionalidade de normas constitucionais originárias ${ }^{71}$.

A situação é diferente quando se fala de normas constitucionais não originárias, fruto do exercício do poder constituinte derivado. Este é condicionado e limitado às formas e conteúdos que o poder constituinte originário comanda e, portanto, é tranquilo o entendimento de que qualquer desvio em relação aos mandamentos constitucionais representa inconstitucionalidade a ser sanada (Silva, 2014, p. 205).

O segundo ponto diz respeito ao status do direito anterior a 5 de outubro de 1988. Afirmar que a validade do direito anterior depende de sua “compatibilidade” com a Constituição Federal não conta toda a história. É preciso primeiramente diferenciar, dentre o conjunto de normas anteriores, as normas constitucionais das normas infraconstitucionais. Estas passam por um processo de filtragem constitucional $^{72}$, uma releitura à luz do novo texto constitucional: todas as normas incompatíveis com o texto constitucional são consideradas

69 A possibilidade de existência de normas constitucionais inconstitucionais foi originalmente explorada por Otto Bachof em sua obra "Normas Constitucionais Inconstitucionais?” (Coimbra, Atlántida Editora, 1994).

${ }^{70}$ Entende-se em ampla maioria o poder constituinte originário, expressão da soberania popular, como poder de fato inicial, ilimitado, incondicionado, indivisível e permanente., caracteres estes atribuídos pela formulação tradicional de Sieyès (Ferreira Filho, 2014, pp. 33-36).

71 O STF corrobora esta posição, sequer conhecendo de ações que buscam a inconstitucionalidade de normas originárias. O leading case é a ADI 815/DF (Relator Ministro Moreira Alves, julgamento em 28.3.1996, Plenário, DJ 10-5-1996) em que se atacava o artigo 45, $\S 1^{\circ}$ da $\mathrm{CF} / 88$, que fixa números máximo e mínimo de depudatos federais por estado e cria distorções representativas. O STF considerou o pedido juridicamente impossível.

${ }^{72}$ Ver SCHIER, Paulo Ricardo. Filtragem Constitucional: construindo uma nova dogmática jurídica. Porto Alegre: Sergio Fabris, 1999. 
automaticamente revogadas, enquanto as normas compatíveis são consideradas recepcionadas pela nova ordem jurídica. Elas são renovadas pela recepção (Ferreira Filho, 2014, p. 116) passando a viger sob um novo fundamento de validade e, eventualmente, com nova interpretação (Barroso, 2009, p. 200; Mendes, Branco e Coelho, 2009, p. 3). Já a Constituição anterior é considerada revogada pela Carta que a substitui, sem necessidade de menção expressa a esta derrogação. A possibilidade de recepção de normas constitucionais depende portanto de expressa previsão constitucional - o fenômeno, na verdade, é o da novação: ocorre a alteração do fundamento de validade da norma, que passa a valer pelo novo texto constitucional ${ }^{73}$.

No Brasil não se adota a teoria da desconstitucionalização, pela qual seria possível a recepção automática de normas formalmente constitucionais anteriores compatíveis (não repetidas e não contrariadas), com um rebaixamento hierárquico para o nível infraconstitucional ${ }^{74}$.

É também necessário distinguir a compatibilidade material da formal. Normas anteriores materialmente incompatíveis com a constituição são consideradas automaticamente revogadas, como dito. Contudo, normas infraconstitucionais que sejam apenas formalmente incompatíveis com a Constituição são tidas como novadas, em um fenômeno chamado de recepção qualificada, ou recepção com eficácia passiva, em que a norma é recebida com o status que a nova Constituição demanda. Tradicionais exemplos são o Código Nacional Tributário (Lei $\mathrm{n}^{\circ} 5.172 / 66$ ), lei ordinária que foi recebida pelo

73 “A vigência e a eficácia de uma nova Constituição implicam a supressão da existência, a perda de validade e a cessação de eficácia da anterior Constituição por ela revogada, operandose, em tal situação, uma hipótese de revogação global ou sistêmica do ordenamento constitucional precedente, não cabendo, por isso mesmo, indagar-se, por impróprio, da compatibilidade, ou não, para efeito de recepção, de quaisquer preceitos constantes da Carta Política anterior, ainda que materialmente não conflitantes com a ordem constitucional originária superveniente. É que consoante expressiva advertência do magistério doutrinário (Carlos Ayres Britto, Teoria da Constituição, p. 106, 2003, Forense) 'Nada sobrevive ao novo Texto Magno', dada a impossibilidade de convívio entre duas ordens constitucionais originárias (cada qual representando uma idéia própria de Direito e refletindo uma particular concepção político-ideológica de mundo), exceto se a nova Constituição, mediante processo de recepção material (que muito mais traduz verdadeira novação de caráter jurídico-normativo), conferir vigência parcial e eficácia temporal limitada a determinados preceitos constitucionais inscritos na Lei Fundamental revogada, à semelhança do que fez o art. 34, caput, do ADCT/1988”. Supremo Tribunal Federal, AI 386.820AgR-ED-EDv-AgR-ED, Relator Mininstro Celso de Mello, julgamento em 24-6-2004, Plenário, DJ de 4-2-2005.

${ }^{74}$ A tese, admitida em países como Portugal é por aqui atualmente defendida por Manoel Gonçalves Ferreira Filho (2014, p. 111). 
ordenamento jurídico vigente com status de Lei complementar devido ao comando do artigo 146 da Constituição Federal de 1988 e o Código Penal, editado como decreto-lei na vigência da Constituição de 1937 e que continua em vigor mesmo não prevendo a Carta atual a figura do decreto-lei (Mendes, Branco e Coelho, 2009, p. 238) .

Uma segunda qualificação necessária diz respeito ao status normativo de certas partes do texto de 5 de outubro de 1988. Aqui referência é feita ao preâmbulo e ao ADCT: enquanto este é considerado como parte constitucional provida de eficácia normativa (Mendes, Branco e Coelho, 2009, p. 41), o preâmbulo é concebidio com eficácia meramente interpretativa, desprovido de eficácia normativa, não sendo considerado “norma central” 75 ao texto constitucional brasileiro (Mendes, Branco e Coelho, 2009, p. 28).

Também é necessário considerar questões relativas à força normativa da Constituição e à eficácia das normas constitucionais, em especial a das normas veiculadoras de direitos fundamentais. Quanto à primeira, com inspiração na obra de Konrad Hesse (2009, pp. 123-146) e nas experiências constitucionais ibéricas do fim da década de 1970, aceitou-se aqui também uma regra de reconhecimento que considera a Constituição como um documento verdadeiramente jurídico e não meramente político (Atienza e Ruiz Manero, 1998, p. 144; Struchiner, 2005, p. 75; Barroso, 2009, p. 262). Sendo normas dotadas da imperatividade inerente das demais normas jurídicas, procurou-se conferir aplicabilidade direta e imediata às normas constitucionais. Foi então necessária a alteração da compreensão de sua eficácia, em especial das normas veiculadoras de direitos fundamentais particularmente os direitos sociais, ditos de segunda geração. Tradicionalmente ${ }^{76}$ consideradas normas programáticas, de eficácia limitada - carecendo de integração pelo legislador ordinário (Mendes, Branco e Coelho, 2009, p. 286) -, ao longo da vivência constitucional houve “um grande esforço para aproximar o tanto quanto possível a eficácia dos direitos sociais à eficácia dos direitos fundamentais (Silva, 2014, p. 574). Passaram as normas veiculadoras de direitos fundamentais a ser consideradas normas de efiácia plena e aplicação direta, de

\footnotetext{
${ }^{75}$ Supremo Tribunal Federal, ADI 2.076, Relator Ministro Carlos Velloso, julgamento em 15-8-2002, Plenário, DJ de 8-8-2003.

${ }^{76}$ A posição canônica é a apresentada por José Afonso da Silva em "Aplicabilidade das normas constitucionais” (2a ed. São Paulo: Malheiros, 2007. A 1ª edição é de 1961).
} 
modo que "as poucas situações em que o Supremo Tribunal Federal deixou de reconhecer aplicabilidade direta e imediata às normas constitucionais foram destacadas e comentadas em tom severo” (Barroso, 2009, pp. 224-225). O relato de uma postura crítico-reflexiva evidencia a aceitação de uma regra de reconhecimento que indique que tais normas possuem eficácia plena, e tal aspecto também deve ser inserido na formulação proposta, que será revisitada ao fim deste capítulo.

4.2

As cláusulas pétreas e o critério supremo do direito brasileiro

Como visto no tópico que tratou da unidade de regras de reconhecimento, é possível e preferível afirmar que todo ordenamento jurídico possui uma única regra de reconhecimento última e que esta pode possuir diversos critérios de validade jurídica do que considerar que cada ordenamento pode possuir diversas regras de reconhecimento últimas. Neste sentido, ao apresentar mais de um critério último de validade jurídica, a regra ordena seus critérios hierarquicamente, em um ranking (Gardner, 2011, p.173); ou, nas palavras de Hart ([1961] 2009, p.136): “quando, como geralmente ocorre, houver diversos critérios hierarquizados por ordem de subordinação e primazia relativa, um deles será considerado supremo”.

Hart parece associar o critério supremo à cláusula Queen-in-Parliament na Inglaterra (e a cláusulas semelhantes nos demais países de soberania parlamentar) e às cláusulas pétreas (também chamadas de entrincheiradas, eternas (eternity clauses)) nos ordenamentos em cujas constituições elas estão presentes ([1961] 2009, pp.136-137):

Podemos afirmar que um critério de validade jurídica ou fonte do direito é supremo se as normas identificadas mediante referência a ele são ainda reconhecidas como normas do sistema mesmo que conflitem com outras normas identificadas mediante referência a outros critérios; enquanto estas últimas não são reconhecidas caso conflitem com as primeiras, identificadas mediante referência ao critério supremo. (...) É evidente que as noções de um critério superior e de um critério supremo se referem apenas a uma posição relativa numa escala e não implicam de modo algum a noção de um poder legislativo juridicamente ilimitado. No entanto, 'supremo' e 'ilimitado' são facilmente confundidos, pelo menos na teoria do direito. Uma razão é que, nas formas mais simples de sistema jurídico, as ideias de norma última de reconhecimento, critério supremo e poder legislativo juridicamente ilimitado parecem convergir. 
Pois, onde quer que exista um poder legislativo não sujeito a limitações constitucionais e que seja competente para privar de juridicidade a todas as outras normas de direito que emanem de outras fontes, a norma de reconhecimento daquele sistema dita que a atuação desse poder constitui o critério supremo de validade. Esta é, de acordo com a teoria constitucional, a situação do Reino Unido. Mas mesmo sistemas como o dos Estados Unidos, no qual não existe esse poder legislativo juridicamente ilimitado, podem perfeitamente conter uma norma última de reconhecimento que fornece um conjunto de critérios de validade, um dos quais é supremo. Isso acontecerá onde a competência legislativa do poder legislativo ordinário seja limitada por uma constituição que não prevê o poder de emenda ou que subtrai algumas cláusulas ao alcance desse poder.

A passagem citada pode levar à conclusão de que os critérios supremos, nos ordenamentos jurídicos em que há constituições com cláusulas que disciplinam e limitam o processo de emenda, seriam as próprias cláusulas constitucionais entrincheiradas. Isto é o que parecem concluir alguns autores norte-americanos como Greenwalt, ao identificar no artigo V da Constituição americana o critério supremo. Naquele ordenamento, praticamente todas as emendas formalmente constitucionais são consideradas válidas (Greenwalt, [1987] 2009, p.12), pois só há hoje uma limitação material ao poder de emenda: que nenhum estado perca seu direito de igual número de votos no Senado sem seu consentimento. A posição de Greenwalt parece tratar como uma "qualificação menor” ([1987] 2009, p.11) aquilo que é o cerne da questão para Hart, que inclusive cita o caso norte-americano. Parece que o autor d'O Conceito de Direito quer indicar que as limitações materiais ao poder de emenda expressam a existência e o locus dentro do sistema do critério supremo. Aplicando o raciocínio ao caso brasileiro, seria como dizer que o artigo 60 , $\S 4^{0} 77$ da Constituição Federal de 1988 é o critério supremo do ordenamento pátrio.

Mas mesmo esta interpretação não está livre de problemas: cláusulas pétreas não são os critérios supremos, elas não possuem força por si mesmas. $\mathrm{O}$ argumento remonta ao que já foi dito das próprias constituições, mas cabe aqui uma análise mais detida.

\footnotetext{
${ }^{77}$ Art. 60. $\S 4^{\circ}$ - Não será objeto de deliberação a proposta de emenda tendente a abolir: I - a forma federativa de Estado;

II - o voto direto, secreto, universal e periódico;

III - a separação dos Poderes;

IV - os direitos e garantias individuais.
} 
Caso seja possível alterar o artigo $60, \S 4^{\circ}$ ou o próprio artigo 60 como um todo, ele perderia a posição supostamente hierarquicamente superior para a cláusula que fundamentou a sua alteração; afinal seria esta hipotética cláusula que possuiria a característica de fundamentar normas que prevalecem sobre quaisquer outras normas fundamentadas em outras cláusulas ${ }^{78}$. É necessário, pois, verificar de onde vem a inalterabilidade das cláusulas pétreas, o que justifica falar que elas veiculam critérios hierarquicamente superiores aos demais critérios veiculados por outras normas no ordenamento jurídico ${ }^{79}$.

Não há nada no texto constitucional que indique que elas - ou o artigo 60 como um todo - não possam ser alteradas. Mesmo que o artigo 60 contivesse um hipotético parágrafo sexto, de redação próxima a "Os limites ao poder de emenda contidos neste artigo não podem ser alterados, seja por emenda, revisão, plebiscito, decisão judicial ou qualquer outra forma legal.”, esse hipotético dispositivo, que representaria critério em posição hierárquica superior ao "atual” artigo 60, não resolveria o problema. Seria necessário fundamentar sua validade, e para isto seria necessário olhar na própria constituição (o que também não solucionaria a questão) ou para fora dela: o "entrincheiramento" do texto da cláusula (assim como a disposição de tomar a constituição como norma jurídica superior) não pode derivar dela mesma, e a decisão entre o entrincheiramento ou não da própria constituição ou apenas de suas cláusulas de emendabilidade é uma decisão antecedente e externa ao texto constitucional (Schauer, 1995, pp. 157158).

Em segundo plano, não há nada intrínseco às cláusulas pétreas que proíba tal alteração, não há uma propriedade necessária ao conceito de cláusulas pétreas que proíba sua modificação. $\mathrm{O}$ argumento que se baseia na impossibilidade de o outorgante alterar os termos da outorga de poder (Silva, 2001, p. 17) se esvai

${ }^{78}$ Mesmo que se diga que esta hipotética cláusula seja o resto do artigo 60. Aqui se estaria transferindo o locus do critério supremo do parágrafo quarto para todo o artigo 60. Neste caso, ele seria equiparável ao Artigo V da Constituição Norte-Americana e incidiria no mesmo tipo de problemas narrados na análise que ora é feita, tal qual questionado por Greenwalt ([1987] 2009, p.12): pode uma emenda estabelecer sua própria imutabilidade, ou alterar o próprio artigo 60, ou derrogar toda a Constituição de 1988 de uma vez por todas?

${ }^{79}$ Ainda que, fique claro, as normas veiculadoras de cláusulas pétreas não sejam normas hierarquicamente superiores às demais normas constitucionais. Como antecipado, inexiste hierarquia entre normas constitucionais originárias, que jamais poderão ser declaradas inconstitucionais umas em face das outras (Mendes, Branco e Coelho, 2009, p. 135; Barroso, 2009, p. 167). 
quando se recorda que a decisão pelo entrincheiramento ou não das cláusulas pétreas é uma decisão logicamente anterior e externa ao ordenamento jurídico e à própria constituição, é uma decisão do próprio grupo reconhecedor relevante. Há boas razões para tratar as cláusulas pétreas como entrincheiradas e impedir sua modificação (razões que se baseiam na ideia de que é melhor impedir algumas emendas desejáveis do que permitir muitas emendas indesejáveis) tanto quanto há razões para uma abordagem mais flexível (considerando, por exemplo, a potencialidade de sobre e subinclusão das emendas, e a necessidade de adaptação a novas circunstâncias para que se evite uma "tirania intergeracional”) (Schauer, 1995, p. 158). Advogando pela possibilidade de alteração, no Brasil, encontra-se Ferreira Filho (1995), no que é contraposto, entre outros, por Silva (2001). Esta ausência de uma imutabilidade intrínseca às chamadas cláusulas pétreas pode também ser percebida em uma análise da forma como outros ordenamentos lidam com a mesma decisão. Ainda que no Brasil tomem-se as cláusulas pétreas de modo entrincheirado, na esteira da lição de Sampaio (1954, p. 90), o fato de outros ordenamentos lidarem de formas distintas com a mesma questão mostra apenas que os grupos reconhecedores relevantes reconhecem regras de reconhecimento de conteúdo distinto, não que uma das posições é correta e a outra errada.

Em Portugal, por exemplo, considerou-se a rigidez constitucional excessiva ao incluir um vasto elenco de limites materiais à revisão e que "restringiam grandemente o âmbito e o sentido possível de qualquer revisão constitucional” (Moreira, 2001, p. 273) Assim, em virtude de necessidades econômicas (o país precisava adotar medidas econômicas necessárias para a implantação do Mercado Interno Europeu e esbarrava no caráter predominantemente socialista da Constituição de 1976) a tese da alterabilidade dos limites materiais de reforma constitucional acabou sendo vitoriosa por ocasião da segunda revisão constitucional (Lei Constitucional $n^{0}$ 1/89). Esta modificou o artigo 290 (atual artigo 288), com a supressão da alínea que tratava sobre as organizações populares de base, bem como pela substituição do princípio da apropriação coletiva dos principais bens de produção pelo princípio da coexistência dos três setores (público, privado e social) e a substituição do termo "planificação democrática da economia" por "existência de planos no quadro de 
uma economia mista”. Isto só foi possível graças à, nas palavras de Vital Moreira (2001, pp. 273-274):

interpretação soft das cláusulas pétreas, que as reduziu à salvaguarda de princípios genéricos, mais do que à garantia do concreto regime estabelecido nas formulações constitucionais. Por outro lado, porque se admitiu, como já vos anunciei, a revisão dos próprios limites materiais de revisão, tendo sido eliminados ou modificados - para não dizer suavizados - na revisão de 1989 alguns dos limites originários, libertando, desse modo, para futuras revisões, matérias que de outro modo não poderiam ser revistas. Embora sendo tudo menos pacífico, este expediente permitiu flexibilizar aspectos da Constituição que sua rigidez inicial tornava pouco confortáveis, sob o ponto de vista da adaptação constitucional à evolução da realidade constitucional.

Portanto, a decisão político-jurídica de tomar as limitações materiais como definitivas ou não - seja ela tomada em bases ideológicas ou pragmáticas - é uma decisão exterior à Constituição. A mesma postura restritiva é vista quanto aos limites circunstanciais e aos requisitos formais, estes muitas vezes indevidamente chamados de limites formais, pois são propriamente condição de possibilidade do processo de emenda, como nota Leite (2006, p. 104). A alteração das questões relativas ao processo de emenda - seja para dificultar ou facilitar - também costuma ser rechaçada, apesar de algumas vozes importantes em sentido contrário $^{80}$.

No Brasil adotou-se o entendimento de que há limites intrínsecos, também ditos tácitos ou imanentes ao poder de reforma, que impediriam a alteração do artigo 60 e que serviriam para proteger sua identidade ou os pressupostos democráticos sobre os quais se assenta a constituição (Sampaio, 1954, p. 93; Silva, 2001, p. 29; Barroso, 2009, p. 165). O critério supremo, portanto, não é o artigo 60 (que limita o poder de emenda), mas a disposição político-jurídica exterior à constituição - cujo conteúdo indica que o artigo 60 não pode ser emendado. E quem é o responsável essa formulação? Aqui se percebe nitidamente a influência que o povo tem no reconhecimento dos critérios de validade últimos do direito.

Apesar de ter sido por decisão do STF que no Brasil foi fixado de maneira oficial o entendimento a respeito da teoria dos limites intrínsecos, a ideia foi desenvolvida em nossa comunidade jurídica por Nélson de Souza Sampaio (1954)

\footnotetext{
${ }^{80}$ Como as posições que entendem pela possibilidade de enrijecimento, mas não de flexibilização dos critérios procedimentais (Sampaio, 1954, pp. 95 e 107; José Afonso da Silva, "Limitações ao poder de reforma constitucional", RF 259, p. 76).
} 
e sua obra ainda que indiretamente continua a exercer grande influência, tendo a teoria sido aprimorada por José Afonso da Silva (Leite, 2006, pp. 89 e 99). Mas o que aconteceria caso o STF tivesse decidido de outro modo? O que aconteceria se o STF em futuro julgado declarasse a validade de uma emenda constitucional que ao mesmo tempo revogasse o artigo 60 e abolisse os poderes Legislativo e Executivo e desse todo poder a ele, STF - em clara violação ao artigo 60 , §4 ${ }^{\circ}$, III da Constituição Federal de 1988, que arrola como cláusula pétrea “a Separação dos Poderes”? Ou considerasse válida uma emenda que proibisse o voto de todos

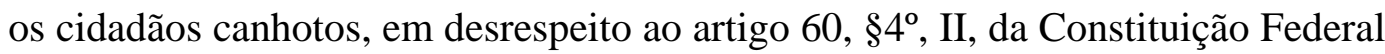
de 1988, que arrola como cláusula pétrea “o voto direto, secreto, universal e periódico.”? Certamente, tais decisões seriam objeto de intensa crítica e resistência, não por estarem violando decisão anterior do próprio tribunal, e não só por violarem o texto original da Constituição, mas por violarem a própria regra de reconhecimento última do direito brasileiro em seu critério supremo, por abandonarem a prática de reconhecimento convergente entre todos os setores da sociedade brasileira, que aceita os elementos do artigo 60, $\S 4^{\circ}$ (a despeito das divergências quanto à extensão deste entrincheiramento) como núcleo duro do pacto constitucional vigente (Mendes, Branco e Coelho, 2009, p. 251).

Afirmar a existência de limites implícitos ao poder de reforma e situar o critério supremo fora do texto da Constituição Federal não faz com que os conceitos representem a mesma coisa ou que sejam coextensivos. Os limites implícitos tradicionalmente reconhecidos na doutrina brasileira dizem respeito (i) ao titular do poder constituinte originário, visto que a soberania popular é pressuposto do regime constitucional democrático e, como tal inderrogável; (ii) ao titular do poder reformador, que não pode renunciar à sua competência nem delegá-la; e (iii) ao procedimento que disciplina o poder de reforma, pois este, como um poder delegado pelo constituinte originário, não pode alterar as condições da própria delegação (Sampaio, 1954, p. 93). Ainda seria talvez possível afirmar que a escolha popular pelo regime republicano presidencialista no plebiscito previsto no artigo $2^{\circ}$ do ADCT e realizado em 21 de abril de 1993 conta como um elemento de decisão do poder constituinte originário e, portanto, teria colocado a forma e o sistema de governo fora do alcance do poder constituinte derivado, passando a integrar o rol de limites não escritos (Leite, 2006, p. 89). 
De todo modo, essas proposições abstratas são tidas como parte não escrita da própria Constituição, não como uma decisão político-jurídica exterior e logicamente anterior a ela. Por mais que o critério supremo de fato incorpore as ideias centrais das cláusulas limitativas implícitas, a convergência em tratar as limitações ao poder de emenda como inalteráveis - eterno enquanto durem - é mais extensa e hierarquicamente superior aos elementos constitucionais não escritos.

\section{3}

\section{Regras de adjudicação e a supremacia judicial "à brasileira"}

Neste tópico, serão tratados alguns pontos relativos ao papel do Poder Judiciário no direito brasileiro. Mais especificamente, propõe-se uma análise da regra de adjudicação do direito brasileiro somada a questões pontuais que decorrem do exercício da função jurisdicional tal qual ocorre no sistema jurídico brasileiro. Recorde-se que a regra de reconhecimento não se confunde com a regra de adjudicação, mas em sistemas complexos - como o brasileiro - a regra última pode apontar para as regras que conferem poderes a determinados sujeitos para decidir sobre a aplicação do direito válido segundo os próprios critérios da regra de reconhecimento.

Novamente, o ponto de partida deve ser a Constituição Federal de 1988. Nela, vê-se a organização do Poder Judiciário no Capítulo III, nos artigos 92 a 126. Note-se a posição de cúpula do Supremo Tribunal Federal, exercendo tanto uma função de Suprema Corte (última instância recursal) quanto uma função de Tribunal Constitucional, com a conjunção de modelos de controle de constitucionalidade (difuso e concentrado) e um sistema de competências originárias (artigo 102); o Superior Tribunal de Justiça, responsável basicamente pela uniformização da legislação federal, entre outras competências atribuídas pelo artigo 105; a Justiça Federal, composta por Tribunais Regionais Federais e Juízes Federais, cuja competência em geral decorre da existência de interesse da União Federal (artigos 108 e 109); a Justiça do Trabalho, composta pelo Tribunal Superior do Trabalho, Tribunais Regionais do Trabalho e Juízes do Trabalho, com competência, em geral, para decidir casos ligados a relações trabalhistas (artigo 114); a Justiça Eleitoral, composta pelo Tribunal Superior Eleitoral, Tribunais 
Regionais Eleitorais, Juízes Eleitorais e Juntas Eleitorais, de competência para decidir questões eleitorais; a Justiça Militar, composta pelo Superior Tribunal Militar, pelos Tribunais e Juízes Militares e com competência para processar e julgar crimes militares (artigo 124) e a Justiça Estadual, composta pelos Tribunais de Justiça estaduais e pelos Juízes de Direito, e cuja competência residual deve ser definida pelas Constituições estaduais (artigo 125, $\S 1^{0}$ ).

Talvez o conjunto de questões mais importante quando o assunto é Poder Judiciário diz respeito à existência (ou não) de uma supremacia judicial no Brasil. Recorde-se o que já foi dito na análise do grupo reconhecedor relevante: diferenciam-se as posições populistas e supremacistas profundas - preocupadas com a identificação do grupo reconhecedor relevante - das correntes populistas e supremacistas superficiais, que debatem a respeito do arranjo institucional vigente ou de qual o melhor arranjo para a tomada de decisões constitucionais. Parte-se aqui de uma premissa populista profunda, que inclui o povo no grupo reconhecedor relevante, para a análise se a melhor explicação para o fenômeno jurídico decorre de uma postura superficial populista ou supremacista.

Deve-se notar, em primeiro lugar, que o direito posto não oferece nenhuma resposta para a pergunta: quem detém a última palavra em questões constitucionais (assim como em questões jurídicas como um todo)? O mais próximo que há é uma indicação, no artigo 102, caput, da Constituição Federal de 1988, que "compete ao Supremo Tribunal Federal, precipuamente, a guarda da Constituição”. Dizer que cabe principalmente ao Supremo Tribunal Federal a defesa da Constituição não significa necessariamente que ele seja o único responsável por tal tarefa, ou, ainda, que sua palavra valha mais que a dos demais Poderes da República, que, como visto, também participam da atividade de reconhecimento do direito e, logicamente, igualmente possuem voz na interpretação constitucional. Atribuir ao Supremo precipuamente a guarda da Constituição poderia significar que este órgão é responsável pela esmagadora maioria das decisões a respeito da constitucionalidade do direito, mas que, em alguns - e importantes - casos, sua decisão não seria última, final. Seria esta a hipótese caso viesse a ser aprovada a Proposta de Emenda Constitucional 33/2011, que pretende devolver ao Congresso Nacional e, em última instância, ao povo em referendo a decisão da constitucionalidade de emendas constitucionais. O chamado "segundo olhar” (second look), característico de modelos dialógicos 
de controle de constitucionalidade, cujo arquétipo é o Canadá, é tema cada vez mais estudado na doutrina constitucional brasileira ${ }^{81}$.

Parece, entretanto, ser realmente o caso de uma supremacia judicial, liderada pelo Supremo Tribunal Federal, com o reconhecimento de que deve caber ao Judiciário a última palavra acerca da interpretação da Constituição e das leis (Mendes, Branco e Coelho, 2009, p. 873; Barroso, 2009, p. 285). Isso não significa dizer que é parte da regra de reconhecimento do direito brasileiro algo como “é direito tudo que o Supremo Tribunal Federal disser que é”. Tal autoridade encontra limites: por exemplo, a Corte está de certo modo limitada na atividade interpretativa pelo sentido linguístico ordinário dos termos empregados, a sua atividade está ancorada pelo texto constitucional (ela é, afinal, guardiã deste mesmo documento); ela também carece de autoridade para decidir sobre algumas “questões políticas”, como visto na impossibilidade de rescisão judicial de veto ${ }^{82}$, na impossibilidade de rescisão judicial da decisão de impeachment, que cabe ao Senado, ou na possibilidade de emendas corretivas de jurisprudência. Os temas serão retomados adiante.

A constatação da supremacia judicial decorre do fato de que os demais agentes públicos e a população tomam como autoritativas as decisões do Supremo Tribunal Federal mesmo que discordem de seu conteúdo. Independente de considerarem a decisão correta ou não, parece haver uma disposição perene na comunidade jurídica em "reconhecer, aceitar e aplicar” (Himma, 2003, p. 160) as decisões do Supremo Tribunal Federal, disposição esta que somente é questionada em casos extremos. Analisando o caso do direito norte-americano, muito próximo ao brasileiro, assevera Himma (2003, p. 162):

Tal comportamento indica que agentes públicos conscientemente praticam uma regra de reconhecimento que confere poderes à Suprema Corte de autoridade final para decider se uma determinada norma formalmente válida se conforma aos critérios substantivos da Constituição. Enquanto os demais agentes públicos se perceberem vinculados até mesmo por decisões incorretas da Corte, isto ocorre porque eles aceitam uma regra de reconhecimento que lhes impõe um dever de segunda ordem de tratar as decisões da Corte como estabelecendo o direito

${ }^{81}$ Apenas a título de referência, dois dos títulos recentemente publicados no tema: TAVARES, R. S.; VALLE, V. R. L.; VIEIRA, José Ribas.; BERMAN, J. G.. Diálogos Institucionais e Ativismo. 1 ${ }^{\mathrm{a}}$. ed. Curitiba: Juruá, 2010; BRANDÃO, Rodrigo. Supremacia Judicial versus Diálogos Constitucionais. Rio de Janeiro: Lumen Juris, 2012.

${ }^{82}$ Confira-se, no tema, a ADPF 1-RJ. Relator Ministro Néri da Silveira, Julgamento 0302-2000, Plenário, Publicação DJ 07-11-2003. 
válido. Enquanto o comportamento dos agentes públicos convergir na satisfação deste dever, pela Tese da Convencionalidade é possível dizer que eles praticam a respectiva regra de reconhecimento.

Contudo, este dever de seguir as decisões do Supremo Tribunal Federal parece ser um dever condicionado ao cumprimento de alguns requisitos pela decisão, como, por exemplo, a necessidade de uma fundamentação adequada e, mais especificamente, uma pertinência com o significado ordinário dos termos utilizados nos textos. Trata-se de um "constraint de plausibilidade” (Himma, 2003, p. 167): as decisões devem ser baseadas em interpretações que possam ser racionalmente baseadas no texto constitucional.

Talvez o constraint seja muito mais flexível que o apresentado: por mais que o público conteste muitas decisões do Supremo Tribunal Federal, para que um julgado tenha sua aplicabilidade negada ele não somente precisa ser incorreto quanto aos seus méritos, mas também desagradar a maioria esmagadora da comunidade político-jurídica. Além disso, a decisão precisa carecer completamente de uma fundamentação - ou apresentar uma fundamentação completamente torpe, como, por exemplo, se os votos de cada Ministro fossem decididos pelo lançar de uma moeda - e não pode guardar relação racional com o texto constitucional ou decisões passadas da Corte (Alexander e Schauer, 2009, pp.190-191).

Independente de quão relaxado se considere o constraint de plausibilidade, o que importa notar é que, como a recusa por parte dos demais agentes em atender a uma decisão do Supremo Tribunal Federal pode gerar uma grave instabilidade institucional sem precedentes em tempos democráticos ${ }^{83}$ e significaria a falência do sistema constitucional, a Corte geralmente procura atendê-las; uma decisão contrária a requisitos tão facilmente atendidos pela quase totalidade das decisões judiciais sugere má-fé por parte da Corte. Assim, os riscos associados à crise institucional que ocorreria com a recusa em seguir uma decisão da Corte criam

\footnotetext{
${ }^{83}$ Não há no Brasil o histórico de confrontos entre Suprema Corte e Presidência ou Congresso como há nos Estados Unidos. Lá são conhecidos os casos de crises institucionais, como o Court packing plan de Franklin Roosevelt ou a afirmação do Presidente Andrew Jackson, em resposta à decisão da Suprema Corte em Worcester v. Georgia, (31 U.S. (6 Pet.) 515 (1832)), que "John Marshall tomou sua decisão; agora deixe-o aplica-la" ("John Marshall has made his decision[;] now let him enforce it.”) (Dorf, 2009, p. 70). No cenário brasileiro atual há, no máximo, ameaças veladas e mascaradas sob a forma de decisões judiciais, projetos de lei e propostas de emenda, e cortes no orçamento.
} 
um forte incentivo para que os agentes públicos tratem as decisões de boa-fé (aquelas que satisfazem os critérios mínimos) como vinculantes - não importanto quão profundamente incorretas elas possam parecer (Himma, 2003, p. 176).

Portanto, seria possível afirmar que este aspecto da regra de reconhecimento do direito brasileiro permite uma formulação provisória do tipo: "Decisões fundamentadas da maioria dos Ministros do Supremo Tribunal Federal devem contar como sendo a interpretação da Constituição a ser seguida, desde que os Ministros estejam de boa-fé procurando identificar o sentido do texto constitucional de acordo com uma metodologia coerente e que a decisão possa ser racionalmente baseada no texto constitucional”. Uma vez que as decisões passem este teste básico, pela regra de reconhecimento adotada no Brasil, o entendimento da Corte prevalece sobre os demais entendimentos na maioria dos casos e gera um dever de obediência (em adaptação de Himma, 2003, p. 168).

Enquanto não sobrevier decisão da Corte, entretanto, os demais agentes estão livres para interpretar e aplicar as normas. Neste sentido, é reconhecida possibilidade de o Chefe do Executivo negar aplicação à lei que fundadamente considere inconstitucional (Barroso, 2009, p. 135), sob sua conta e risco. Uma vez que o Supremo Tribunal Federal se manifeste a respeito do tema, entretanto, deve prevalecer a visão da Corte.

Além desta limitação inicial, presente no constraint de plausibilidade, deve ser reconhecida a possibilidade de “respostas” do Poder Legislativo a decisões do Supremo Tribunal Federal. Em um primeiro plano, é possível falar na reedição indefinida de leis com conteúdo semelhante a outra já declarada inconstitucional pelo Supremo Tribunal Federal. Entretanto, esta medida serviria mais para recolocar a questão em pauta na Corte do que para propriamente desafiar a autoridade do $\mathrm{STF}^{84}$. Diferente é a hipótese das chamadas "emendas corretivas de jurisprudência”. Aqui o Congresso Nacional edita emenda

${ }^{84}$ A possibilidade de legislação ordinária sobrepor-se às decisões judiciais é característica da doutrina da Soberania Parlamentar, presente em ordenamentos como o do Reino Unido: as Cortes determinam a validade e os efeitos dos Atos do Parlamento, mas o Parlamento pode sempre relegislar para derrotar as Cortes, sujeitando-se, novamente, à determinação destas dos efeitos jurídicos da norma relegislada (Gardner, 2011, p.170). Esta dinâmica não faz muito sentido em sistemas jurídicos com constituições com as duas garantias mais comuns de sua estabilidade e soberania: um grau mínimo de rigidez decorrente de um procedimento mais gravoso para sua alteração e a existência de uma fiscalização, normalmente pelo Poder Judiciário, das violações ao texto constitucional (Sgarbi, 2007, p. 350). 
constitucional com conteúdo oposto a uma decisão prévia do Supremo Tribunal Federal, que não procura conformar a emenda a seu entendimento anterior, mas aceita a alteração no plano constitucional como válida e adapta suas decisões ao novo dispositivo constitucional.

Exemplo clássico foi a edição da Emenda Constitucional 29/00 para permitir progressividade fiscal do IPTU. Antes da EC $29 / 00^{85}$, o STF considerava inconstitucionais as leis municipais que apresentavam regime de progressividade fiscal, amparado na natureza real do tributo e no caráter eminentemente pessoal, relativo à capacidade econômica do contribuinte, da progressividade baseada no artigo 145, $\S 1^{0}$ da Constituição Federal $^{86}$. Com a edição da EC 29/00, que expressamente previu um regime de progressividade para o tributo, a Corte foi obrigada a mudar seu entendimento, reconhecendo a constitucionalidade das normas posteriores à alteração constitucional ${ }^{87}$.

De todo modo, como tais emendas corretivas de jurisprudência representam limite claro à supremacia judicial ao derrotar as interpretações anteriores da Corte, elas ensejam uma cláusula de exceção à formulação da supremacia judicial anteriormente apresentada, que será posteriormente revisada.

Por fim, cabe destacar o papel dos critérios interpretativos também como fatores de limitação da discricionariedade judicial, papel este que tornaria os critérios e métodos interpretativos merecedores de menção na regra de reconhecimento (Himma, 2003, p. 171). Ademais, a identificação dos critérios é importante pela função destes de auxiliar no processo interpretativo e, portanto, de identificação do direito válido. Se é praticamente inviável eliminar a possibilidade de inconsistências entre os critérios coexistentes em um mesmo ordenamento (Gardner, 2011, pp.202-203), deve ser ao menos realizada sua identificação.

${ }^{85}$ A emenda alterou o artigo 156, $\S 1^{\circ}$ da Constituição Federal para a seguinte redação:

$\S 1^{\circ}$ Sem prejuízo da progressividade no tempo a que se refere o art. 182 , $\S 4^{\circ}$, inciso II, o imposto previsto no inciso I poderá: I - ser progressivo em razão do valor do imóvel; e II - ter alíquotas diferentes de acordo com a localização e o uso do imóvel.

${ }^{86}$ Ver Recursos Extraordinário de números 153.771; 192.737; 193.997; 194.036; 197.676 e 204.827.

${ }^{87}$ O Tribunal inclusive editou o enunciado de Súmula 668: "É inconstitucional a lei municipal que tenha estabelecido, antes da Emenda Constitucional $n^{\circ}$ 29/2000, alíquotas progressivas para o IPTU, salvo se destinada a assegurar o cumprimento da função social da propriedade urbana". 
É possível afirmar que as práticas de reconhecimento não identificam meramente o documento de 5 de outubro de 1988 em abstrato ou com apenas uma metodologia interpretativa textual; elas identificam a existência de uma multiplicidade de métodos interpretativos aceitáveis, como, por exemplo, os elementos tradicionais de interpretação textual, histórica, teleológica e sistemática (Barroso, 2009, pp. 290; Mendes, Branco e Coelho, 2009, pp. 119-131; Dimoulis e Lunardi, 2013, pp. 259-262), além de métodos específicos de interpretação constitucional, como os ditos "princípios" de supremacia da constituição; presunção de constitucionalidade das leis e atos normativos; de interpretação conforme à Constituição - e a correlata porém distinta declaração parcial de inconstitucionalidade sem redução do texto (Dimoulis e Lunardi, 2013, pp. 265272) -; unidade da Constituição; razoabilidade ou proporcionalidade; e efetividade (Barroso, 2009, pp. 297-305; Mendes, Branco e Coelho, 2009, pp. 132-143), entre outros reconhecidos pela jurisprudência e doutrina. Mais até que identificar somente os diversos critérios e métodos interpretativos, a regra de reconhecimento deveria estabelecer, para Alexander e Schauer (2009, pp.183-184), critérios de adequação entre as metodologias concorrentes.

No ordenamento brasileiro não há uma cisão tão profunda como no direito norte-americano entre originalistas (que entendem que o sentido das provisões constitucionais foi fixado no período de sua promulgação e que, portanto, é necessário recorrer às intenções dos legisladores ou ao sentido ordinário que as expressões possuíam) e os defensores da “Constituição viva” (living constitution), de uma constituição que evolua com o tempo e a sociedade americana, mesmo sem alterações formais em seu texto (Gardner, 2011, p.198). Aqui os métodos hermenêuticos tradicionais, ainda que utilizados na esmagadora maioria dos casos fáceis e de menor relevância político-social, parecem ser deixados em segundo plano na jurisdição constitucional. Nesta arena, em que os holofotes voltam-se todos ao Supremo Tribunal Federal como guardião da Constituição, parecem prevalecer métodos interpretativos que privilegiam a efetividade das normas constitucionais, como o hermenêutico-concretizador propalado por Hesse (2009, pp. 108-117) e a utilização de técnicas como a interpretação conforme à constituição (Hesse, 2009, pp.118-122; Barroso, 2009, pp. 301-302; Mendes, Branco e Coelho, 2009, p. 141; Dimoulis e Lunardi, 2013, p. 265) e a já citada ponderação. 


\section{4}

\section{Regras de alteração: reformas e mutações constitucionais}

A regra de alteração indica quem e como é possível introduzir novas normas e revogar ou alterar as vigentes. Segundo Hart ([1961] 2009, p.124):

Haverá, evidentemente, uma ligação muito estreita entre as normas de modificação e as normas de reconhecimento, pois, quando existirem as primeiras, as últimas deverão necessariamente incorporar uma referência à atividade legislativa como traço identificador das normas, embora seja desnecessária a referência a todos os detalhes processuais envolvidos nessa atividade.

A regra de reconhecimento deve, portanto, fazer referência, indicar quais são os contornos da regra secundária de alteração. A referência à regra de alteração, contudo, não quer dizer que os dispositivos constitucionais desta última façam parte da própria regra de reconhecimento.

No Brasil são duas as formas de alteração das normas vigentes: a primeira faz referência à própria atividade legiferante, dá conta de como o direito posto é criado e alterado. Nesta seara, são três os núcleos normativos:

O primeiro, referente à própria alteração da Constituição (artigo $60^{88}$ ), além da recepção dos tratados internacionais sobre direitos humanos votados como emendas constitucionais (art. $5^{\circ}, \S 3^{\circ}$ ), e à produção de atos normativos primários do direito federal (e nacional), está contido nos artigos 59 a $69^{89}$ da Constituição. Em geral, estas normas devem ser produzidas de acordo com as competências legislativas dispostas nos artigos 22 (competência privativa) e 24 (competência concorrente) da Constituição Federal. Lá estão contidas as formas e os procedimentos básicos para o processo legislativo no Congresso Nacional, abrangendo emendas à Constituição; leis complementares; leis ordinárias; leis delegadas; medidas provisórias; decretos legislativos; resoluções.

${ }^{88}$ Merece referência também o procedimento de revisão constitucional, efetuada de acordo com o artigo $3^{\circ}$ do ADCT. A revisão deu origem apenas a seis Emendas Constitucionais de Revisão, que não alteraram aspectos substanciais do texto e hoje considera-se esgotada a possibilidade de nova revisão constitucional. Ver decisão do Supremo Tribunal Federal na ADI 981 MC/PR, Relator Ministro Néri da Silveira, julgamento em 17-12-1994, Plenário, DJ de 5-81994.

${ }^{89}$ Seção VIII do Capítulo I do Título IV da Constituição Federal de 1988. 
O segundo núcleo diz respeito à criação de normas por estruturas administrativas fora do Poder Legislativo. Aqui entram tipos normativos primários e secundários produzidos pelo Poder Executivo, como os decretos regulamentares (também chamados de regulamentos de execução), atos normativos secundários contidos no artigo 84, IV da Constituição Federal ${ }^{90}$ e os decretos ditos autônomos (regulamentos autônomos), atos normativos primários contidos no artigo 84, VI da Constittuição Federal ${ }^{91}$ (Moreira Neto, 2009, pp. 649-650). Também são incluídos atos normativos produzidos pelo Conselho Nacional de Justiça (CNJ), estrutura administrativa vinculada ao Poder Judiciário e prevista no artigo 103-B da Constituição Federal. As resoluções do CNJ podem inclusive possuir natureza normativa autônoma, como decidido pelo Supremo Tribunal Federal na Ação Declaratória de Constitucionalidade 12-DF ${ }^{92}$. Questão altamente controvertida diz respeito à natureza jurídica dos enunciados de súmula vinculantes editados pelo Supremo Tribunal Federal com base no artigo 103-A da Constituição Federal (Dimoulis e Lunardi, 2013, p. 330): caso se considere que possuem natureza jurídica de ato normativo primário e não de ato jurisdicional as súmulas vinculantes podem ser contadas no elenco aqui apresentado.

O terceiro núcleo agrega as instâncias federativas brasileiras. Em respeito ao direito estadual, há a previsão das Constituições Estaduais (artigo 25, caput da Constituição Federal) e da competência legislativa inscrita no artigo 25, §1º , além da competência legislativa concorrente do artigo 24. Em relação ao direito municipal, há a previsão de Leis Orgânicas no artigo 29 e de competência legislativa no artigo 30. Por fim, o Distrito Federal tem sua Lei Orgânica prevista no artigo 32, caput e suas competências legislativas no parágrafo primeiro do mesmo artigo.

A segunda forma de alteração do direito vigente diz respeito às alterações que independem de ação legislativa ou regulamentar. Aqui especial atenção merece a alteração constitucional informal, ou seja, alteração do significado do

\footnotetext{
${ }^{90}$ IV - sancionar, promulgar e fazer publicar as leis, bem como expedir decretos e regulamentos para sua fiel execução;

${ }^{91}$ VI - dispor, mediante decreto, sobre: a) organização e funcionamento da administração federal, quando não implicar aumento de despesa nem criação ou extinção de órgãos públicos; b) extinção de funções ou cargos públicos, quando vagos.

92 Supremo Tribunal Federal, ADC 12-DF. Relator Ministro Carlos Ayres Britto, Julgamento em 20-08-2008, Plenário, DJe 18-12-2009.
} 
texto constitucional independente de alteração do texto em si, também chamada de mutação constitucional (Hesse, 2009, p. 151). Como a norma não se confunde com o texto, pode aquela mudar sem que este seja alterado (Mendes, Branco e Coelho, p. 263). Nas palavras de Barroso (2009, pp. 125-126):

Mutação constitucional consiste em uma alteração do significado de determinada norma da Constituição, sem observância do mecanismo constitucionalmente previsto para as emendas e, além disso, sem que tenha havido qualquer modificação de seu texto. Esse novo sentido ou alcance do mandamento constitucional pode decorrer de uma mudança na realidade fática ou de uma nova percepção do Direito, uma releitura do que deve ser considerado ético ou justo. Para que seja legítima, a mutação precisa ter lastro democrático, isto é, deve corresponder a uma demanda social efetiva por parte da coletividade, estando respaldada, portanto, pela soberania popular.

O reconhecimento da possibilidade de alteração constitucional fora de seu texto advém da constatação anteriormente feita de que a constituição não é autossuficiente e nem se esgota em seu texto. As constituições estão necessariamente sempre sujeitas a alterações enquanto os pressupostos que lhes suportam são alterados, mesmo que seja o caso que a alteração dos pressupostos não possa ser concebida senão em termos factuais ou pré-juridicos. Vê-se, pois, a diferença entre a alteração interior à constituição e a alteração exterior à constituição, derivada diretamente de uma alteração na própria regra de reconhecimento. De acordo com Schauer (1995, p.160-161):

O processo de alteração constitucional, portanto, pode ocorrer em dois níveis. No nível constitucional, ela pode ocorrer dentro dos contornos da própria constituição, seja de acordo com uma leitura literal da cláusula de emenda ou de acordo com uma compreensão interpretativa consistente com o entendimento do que a constituição engloba. Mas porque constituições devem sua “constitucionalidade” às condições lógica e politicamente antecedentes, o processo de emenda constitucional também pode ocorrer em um outro nível, quando essas condições lógica e politicamente antecedentes forem elas próprias alteradas. Porque essas condições antecedentes não são elas próprias jurídicas ou constitucionais em nenhum sentido relevante desses termos, contudo, resta necessariamente o caso que constituições estão sempre sujeitas a emenda por alterações - emendas - nas práticas dos cidadãos, nas práticas das autoridades públicas, e nas práticas dos juízes (...) E quando essas práticas ocorrerem será necessariamente uma questão política e moral a referente ao status que a constituição e seus dispositivos devem possuir.

A mutação constitucional significa, em última instância, que determinados critérios de validade contidos no texto constitucional estão em descompasso com os critérios de validade aceitos pela comunidade político-jurídica local, que uma mudança na regra de reconhecimento não foi acompanhada por uma mudança formal no texto constitucional, ou o que constitucionalistas chamariam de uma 
contradição entre "situação constitucional” e "lei constitucional” (Hesse, 2009, p. 152). A mutação decorre, portanto, da alteração social e política das fundações e pressupostos extraconstitucionais (Schauer, 1995, p.156).

Note-se que a mutação não precisa necessariamente ser veiculada apenas por decisões judiciais. Claro, juízes possuem o poder de alterar o direito por meio de decisões que empreguem a cláusulas constitucionais sentido distinto do literal ou do utilizado por outros juízes (Gardner, 2011, p.199).

No Brasil, deve ser reconhecida a importância do Poder Judiciário e, especificamente, do Supremo Tribunal Federal como agente catalizador de mutações constitucionais, com notáveis exemplos como a ampliação do escopo de proteção da privacidade do indivíduo disposta no artigo $5^{\circ}$, XI, da Constituição Federal, e questão das relações homo-afetivas: no julgamento da Arguição de Descumprimento de Preceito Fundamental 132-RJ, o Supremo Tribunal Federal decidiu que o rol de entidades familiares do artigo 226 da Constituição Federal não é taxativo, permitindo o reconhecimento de novas entidades familiares, como a composta por pessoas do mesmo sexo. Uma tentativa mal sucedida de mutação constitucional ocorreu no julgamento da Reclamação 4335, em que o ministro relator Gilmar Mendes argumentou pela alteração da norma contida no artigo 52, $\mathrm{X}$ da CF/88: Mendes pretendia afirmar como norma uma atuação preeminente do STF e a natureza meramente declaratória do ato do Senado Federal na suspensão da execução da lei declarada inconstitucional pelo STF no controle incidental. Seu voto recebeu severas críticas da comunidade jurídica e não conquistou a maioria dos votos no tribunal, permanecendo o caráter constitutivo da atuação do Senado. De fato, não parecem ser verificáveis os elementos necessários para a mutação constitucional, quais sejam, temporal e social, este relativo à relevância interpretativa a elementos externos aos enunciados interpretados (Dimoulis e Lunardi, 2013, p. 287).

Assim como o STF não é o único agente responsável pela interpretação constitucional, ele também não é o único agente que pode operar uma mutação constitucional: o Poder Legislativo pode, por ato normativo primário, procurar modificar a interpretação que tenha sido dada a alguma norma constitucional. "É possível conceber que, ensejando a referida norma mais de uma leitura possível, o legislador opte por uma delas, exercitando o papel que lhe é próprio, de realizar escolhas políticas.” (Barroso, 2009, p. 132). Note-se que mutação por iniciativa 
legislativa ordinária não pode ser confundida com as emendas constitucionais corretivas de jurisprudência, que configuram, como visto, limitação à supremacia judicial. Nas emendas corretivas, prevalece a posição do Legislador, enquanto que os atos normativos primários que procuram alterar o sentido de determinada parte da Constituição precisam ser chancelados pelo Poder Judiciário. Também o Poder Executivo pode procurar influenciar no sentido de alterar o texto constitucional por meio da própria prática de aplicação da Constituição na sua atividade precípua de execução das atividades estatais. Seria a hipótese, por exemplo, caso o Governo Federal passasse a tratar a união de pessoas do mesmo sexo como entidade familiar para fins previdenciários antes e independente de qualquer decisão judicial ou alteração legislativa.

Por fim, quanto aos limites da mutação constitucional, a doutrina brasileira identifica dois (Mendes, Branco e Coelho, p. 263; Barroso, 2009, pp. 127-128): (i) as possibilidades semânticas do relato da norma, ou seja, os sentidos possíveis do texto que está sendo interpretado; e (ii) a preservação dos princípios fundamentais que dão identidade àquela específica Constituição. "Se o sentido novo que se quer dar não couber no texto, será necessária a convocação do poder constituinte reformador. E se não couber nos princípios fundamentais, será preciso tirar do estado de latência o poder constituinte originário”. Não se aceita, portanto, a mutação constitucional inconstitucional - a nova interpretação não pode colidir com o próprio texto. Isto porque a interpretação pressupõe fidelidade mínima ao texto, e interpretação contra legem não seria verdadeiramente interpretação. Como indicado anteriormente, exige-se das decisões do Poder Judiciário respeito ao constraint de plausibilidade.

\section{5}

A incorporação de fatores morais e os princípios na Constituição brasileira

Cabe, por fim, analisar, sob uma perspectiva positivista inclusiva, a incorporação, nos critérios últimos de validade jurídica do direito brasileiro, de “princípios de justiça ou valores morais substantivos”, que "podem integrar o conteúdo das restrições jurídicas constitucionais”, tal qual admitido em abstrato por Hart ([1961] 2009, pp. 319-320). 
Princípios têm como principal traço seu caráter "não conclusivo”, pois apesar de indicarem uma decisão eles não a determinam e precisam ser ponderados em relação a outros (Hart, [1961] 2009, p.339). Esta indeterminação de conteúdo não impede seu reconhecimento como critério de validade em uma regra de reconhecimento. Em verdade, Hart afirma tanto que não há nada nos princípios que os impeça de serem reconhecidos por critérios de fonte quanto não há impedimentos para que a regra de reconhecimento adote critérios últimos de validade jurídica que não sejam somente critérios de fonte, mas que incorporem, por meio destas cláusulas abertas, fatores e considerações morais ([1961] 2009, p. 341).

No ordenamento jurídico atual, estes fatores morais podem ser vistos sob dois aspectos. Em primeiro lugar, quando a regra de reconhecimento última aponta para a Constituição Federal, ela aponta para um texto normativo repleto de referências a cláusulas impregnadas de valores de moralidade substantiva. Da menção à dignidade da pessoa humana como fundamento da República Federativa do Brasil (artigo $1^{\circ}$, III da Constituição Feeral de 1988) e da construção de uma sociedade "livre, justa e solidária” como objetivos fundamentais da República (artigo $3^{0}$ da Constituição Federal de 1988), passando por uma extensa carta de direitos e garantias fundamentais (artigos $5^{\circ}$ a 17) até a disposição de legalidade, impessoalidade, moralidade, publicidade e eficiência como princípios norteadores da atuação da Administração Pública (artigo 37, caput, da Constituição Federal de 1988), a Carta de 1988 apresenta diversas normas jurídicas da espécie princípios “padrões jurídicos variáveis” na terminologia hartiana (Hart, [1961] 2009, p.339) - que remetem a “algum propósito, objetivo, atribuição de direito ou valor” (Hart, [1961] 2009, p. 336).

No caso brasileiro, quando uma autoridade pública nomeia algum parente para um cargo em comissão ou de confiança, ela não está apenas violando um enunciado de súmula vinculante do Supremo Tribunal Federal (Enunciado número 13), ou o princípio constitucional da impessoalidade contido no citado artigo 37, caput. O ato administrativo da malfadada nomeação é inválido, em última instância, pois contrário ao valor da impessoalidade nos tratos da coisa pública, da res publica, corolário de toda instituição republicana. Do mesmo modo, se o Governo Federal pretendesse (re)estabelecer um sistema de censura prévia às manifestações artísticas e jornalísticas, este ato seria contrário não 
somente ao artigo $5^{\circ}$, IX, da Constituição Federal, mas em última instância ao valor de liberdade compartilhado por toda a sociedade que este dispositivo jurídico densifica e incorpora ao ordenamento jurídico brasileiro.

Assim, não é todo e qualquer elemento de moralidade que serve como critério de validade jurídica, mas tão somente aqueles que são compartilhados pela sociedade brasileira e reconhecidos como incorporados ao direito pátrio pela Constituição Federal, que figura como critério jurídico hierarquicamente superior no direito brasileiro, de acordo com a regra de reconhecimento aqui aceita. É ela o farol que sinaliza e orienta o intérprete na identificação inicial do material jurídico, como afirmou-se anteriormente e cabe aqui frisar. Afirmar que valores são indiretamente incorporados aos critérios de validade jurídica por meio da Constituição implica dizer que há uma regra de reconhecimento que especifica as fontes do direito e as relações de primazia e subordinação entre elas (Hart [1961] 2009, p. 343). Como indicado anteriormente, a convergência não é absoluta, havendo espaço para desacordos morais razoáveis dentro do processo interpretativo dos critérios últimos de validade jurídica, o que não desnatura a regra de reconhecimento: “a regra de reconhecimento, bem como as normas específicas do direito identificadas mediante referência a ela, podem apresentar uma 'penumbra’ de incerteza” (Hart, [1961] 2009, p.325). A questão é, portanto, o grau de incerteza que um sistema jurídico pode tolerar para que lhe seja possível qualquer evolução significativa. É necessário, portanto, que o sistema possua meios de resolver as situações conflituosas.

No Brasil, as colisões entre princípios costumam ser solucionados com base no mecanismo de ponderação. Aqui, a ponderação serve mais de ensejo à aplicação dos princípios interpretativos (ou postulados) da proporcionalidade/ razoabilidade $^{93}$ - mais na linha do direito alemão -, do que à aplicação de standards genéricos ou específicos, como é típico do direito norte-americano. Em verdade, o uso da proporcionalidade no processo de ponderação assume hoje um papel central no direito brasileiro, servindo para a solução de praticamente qualquer problema interpretativo, quase como "um rótulo para voluntarismos e

${ }^{93}$ Apesar da preferência do autor pelo tratamento de proporcionalidade e razoabilidade como espécies normativas distintas e como postulados, a esmagadora maioria dos doutrinadores e operadores do direito faz referência a proporcionalidade e razoabilidade de modo intercambiável e com a natureza de princípios, de modo que o tratamento aqui dispensado respeitará este padrão 
soluções ad hoc, tanto as bem-inspiradas como as nem tanto” (Barroso, 2009, p. 337). 


\section{5 \\ Conclusão}

Apesar de pouco debatido no Brasil, H.L.A. Hart é comumente celebrado como um dos mais influentes pensadores e detentor de uma das mais sofisticadas teorias positivistas, tendo sido o responsável pelo renascimento da filosofia e teoria do direito no meio do século XX nos países de língua inglesa. Ele “carregou a tocha” da tradição positivista e hoje qualquer debate nesta área da ciência jurídica não pode prescindir de seus ensinamentos, ao menos para que, criticandoos, sejam tomados como ponto de partida para novas descobertas.

O presente trabalho procurou partir do arcabouço positivista hartiano para avançar uma análise em um dos temas centrais em sua teoria: a regra de reconhecimento. Aqui também foi feito um exame conceitual das propostas de Hart, não para destruí-las, mas, ao contrário, para avançar uma leitura democrática a respeito do grupo responsável pela prática social identificada com a regra secundária de reconhecimento, o que foi desenvolvido nos Capítulos 2 e 3, e para testar sua aplicabilidade ao ordenamento jurídico brasileiro, o que foi devenvolvido no Capítulo 4.

As hipóteses de trabalho desta dissertação, portanto, envolveram: A) a partir de problemas conceituais encontrados na leitura canônica da obra de Hart problemas ditos de circularidade e normatividade - procurou-se apresentar uma proposta de concepção da regra de reconhecimento em que o grupo reconhecedor relevante seja composto não somente os juízes ou officials, mas também a sociedade civil; B) a possibilidade de descrição dos contornos da regra última de reconhecimento do direito brasileiro; e C) como aplicação das conclusões teóricas de A) na hipótese B), o mapeamento da regra de reconhecimento do direito brasileiro olhando-se não somente para as práticas do Poder Judiciário ou dos agentes públicos eleitos e estatutários, mas também para a prática convergente na comunidade político-jurídica brasileira, englobando os operadores do direito, a doutrina, cidadãos engajados, etc. 
Iniciou-se o estudo de aspectos conceituais com a caracterização da regra de reconhecimento como uma regra social e a sua posição entre o mundo jurídico e o sócio-político. Afirmou-se que a regra não consta em nenhum documento jurídico, mas é percebida, como toda regra social, na análise das práticas sociais convergentes de determinado grupo. Ela poderia conter formas das mais variadas, a depender do grau de complexidade do respectivo sistema jurídico: desde uma indicação de que faz parte do direito tudo aquilo que o Rei (ou o Parlamento, um Supremo Tribunal ou até um velho ancião) disser, até critérios mais complexos, em sociedades cujo sistema possua várias fontes, envolvendo a abertura para a compatibilidade do ordenamento inferior a uma Constituição, de acordo com a sua interpretação pelos órgãos para tanto instituídos. Foram também identificadas algumas de suas funções, apesar de não haver convergência na doutrina a respeito de sua classificação. Destacadas foram as funções epistêmicas (de identificação do direito), validatórias (ao determinar que normas são válidas e quais não) e normativa, predicada na assunção que é papel da regra de reconhecimento conferir normatividade ao direito.

A sua relação com os conceitos correlatos de constituição e sistema jurídico foi estudada em detalhes e afirmou-se que a melhor solução para a questão da fonte de validade e autoridade da constituição reside na disposição permanente da comunidade reconhecedora em aceitar uma regra de reconhecimento que identifique na constituição a norma jurídica hierarquicamente superior dentro do sistema. Notou-se, portanto, um erro comum a muitos constitucionalistas, que procuram alguma coisa nas constituições permita tal juízo, caindo em um paradoxo de auto-referência. Por sua vez, indagar o fundamento de validade da regra de reconhecimento seria fazer a pergunta errada, assim como questionar a metricidade da barra padrão do metro. Se a regra de reconhecimento está fora do sistema, ela não pode ser dita válida ou inválida validade é um conceito utilizado dentro de um sistema de normas no qual o status de uma norma depende da satisfação de critérios impostos por outra norma superior à primeira (e, de modo último, pela própria norma de reconhecimento): ela não é válida ou inválida, mas seu uso é simplesmente aceito como apropriado.

A possibilidade de existência de uma única regra de reconhecimento por ordenamento jurídico que apresente diversos critérios ou a viabilidade conceitual de diversas regras de reconhecimento últimas coexistirem no mesmo sistema 
jurídico foi também avaliada, afirmando-se que é possível reconciliar as posições de unidade ou pluralidade da regra de reconhecimento. As diversas posições a respeito da tormentosa questão ontológica da regra foram apresentadas e afirmouse a natureza de regra social constitutiva, convencional unicamente no sentido atribuído por Hart: ou seja, de que o fato de a mesma regra ser seguida pelos demais agentes dentro da comunidade reconhecedora (o fato da convergência) é necessariamente ao menos parte das razões para seguir a regra.

Aceitar a regra, por sua vez, significa falar na existência de uma "atitude normativa específica” de tomar esses comportamentos como guias de conduta para si e para os demais, como razão e justificação para ação e crítica. Falar em aceitação é falar no ponto de vista interno e na “atitude crítico-reflexiva” que lhe é característica, de modo que (i) os desvios da regra sejam vistos como erros e portanto sujeitos a críticas, (ii) as ameaças de desvio sofram pressão no sentido da obediência; e (iii) que o próprio desvio seja visto como uma boa razão para a crítica e que esta seja considera justificada ou legítima tanto pelos que criticam quanto pelos que são criticados. Os conceitos de aceitação e de ponto de vista interno possuem elementos cognitivos e volitivos, mas nenhum deles implica a necessidade de um conhecimento ou expertise jurídica mínima para que o padrão de comportamento seja identificado e seguido. Também foi mostrado que não é necessário perquirir os motivos ou razões para a adoção do padrão: a aceitação não implica uma aprovação moral ou a legitimidade política da regra, mas indica tão somente esta disposição em tomar a regra como razão para agir, como guia de condutas e críticas.

A aceitação é uma atitude permanente, e assim a prática de reconhecimento deve ser entendida. O presentismo prevalece, e são as atitudes atuais que indicam qual a relevância das práticas e entendimentos passados. Não há, pois, como se fixar um momento específico para o qual deve-se olhar a fim de identificar a regra de reconhecimento que dá o fundamento de validade do ordenamento jurídico, ainda que momentos relevantes - como a promulgação de constituições escritas - possam ser tratados como tal pela teoria constitucional, por exemplo. Na verdade, é essa dinâmica de continuidade que dá sentido ao processo de alteração da regra, abrindo a possibilidade de que a regra reconheça como jurídicas normas que antes não teriam o mesmo status. Como toda regra social, por definição, a regra de reconhecimento pode ser alterada ao longo do 
tempo, bastando que ocorra a alteração da prática dos sujeitos relevantes. Alguns casos centrais e outros problemáticos de alteração na regra foram estudados, mostrando-se como as alterações podem ser totais ou apenas parciais, e estas interiores ou exteriores à constituição.

No Capítulo 3 algumas importantes questões foram levantadas com o objetivo de questionar a leitura canônica da regra de reconhecimento, que identifica o grupo reconhecedor relevante apenas nos juízes ou, quando muito, nos officials. O chamado ordenamento jurídico mínimo de Hart - composto por dois elementos necessários e suficientes: (i) a aceitação da regra de reconhecimento por juízes/officials e (ii) a aquiescência e o cumprimento das normas validadas pela regra de reconhecimento pelo povo - apesar de representar um caso central do conceito de direito, foi exposto aqui como um caso patológico e de penumbra do conceito de sistema jurídico por meio da análise de outros relevantes aspectos conceituais da regra de reconhecimento.

O primeiro diz respeito à distinção entre regras primárias secundárias e destas entre si, com a identificação da regra de reconhecimento como categoria conceitualmente independente das demais, rechaçando-se assim críticas que procuram desvalorizar o instituto ora estudado. Deste debate pôde ser percebido o primeiro problema que assola a leitura canônica: a identificação das regras jurídicas depende da prática dos officials, e a identificação dos officials depende de regras jurídicas, que por sua vez dependem da prática dos officials. Para sanar esta circularidade a doutrina apresenta diversas propostas; nenhuma delas, contudo, é satisfatória, pois sofrem de outros problemas que as inviabilizam ou, ao menos, muito as enfraquecem

Em seguida, procurou-se abordar como - caso adote-se a premissa de que uma teoria do direito tem que explicar como o direito possui autoridade - a normatividade do direito advém da regra de reconhecimento. Para tanto, foram analisadas algumas categorias fundamentais ao estudo da obra hartiana, como os de autoridade, normatividade, regras constitutivas, regras que conferem poderes e de regras que impõem deveres. A regra de reconhecimento impõe uma obrigação de seguir as normas por meio delas reconhecidas, e a sua própria normatividade foi explicada em termos de sua aceitação e de seu caráter convencional.

Esta discussão levou à identificação do segundo problema apresentado pela leitura canônica: o sistema jurídico mínimo de Hart sofre de um dos mesmos 
problemas que o próprio Hart identifica na teoria imperativa de Austin, carecendo de normatividade em relação à população, que não aceita a regra de reconhecimento e é obrigada a obedecer as regras primárias pelos officials identificadas por meio dela. Seu sistema jurídico mínimo não é menos coercivo que o sistema austiniano, sendo comparável à situação do assaltante por ele descrita. Hart comprometeu-se não somente com a afirmação que não é verdade, para todo sistema jurídico possível, que a obrigação legal seja puramente coerciva; ele optou por abraçar a tese de que é verdade, para todo sistema jurídico possível, que a obrigação legal não seja puramente coerciva. Para além do claim que a obrigação jurídica não é essencialmente coerciva, Hart afirmou que a obrigação jurídica é conceitualmente não-coerciva, e esta segunda afirmação é incompatível com seu sistema mínimo, pois nele a relação dos agentes públicos que internalizam as regras secundárias com os cidadãos que apenas obedecem as regras primárias é uma relação puramente coerciva. Os cidadãos não possuem obrigação jurídica de seguir o direito, eles são obrigados (coercivamente pelos officials) - na clássica distinção feita pelo próprio Hart - a seguir o direito. A sua noção de aceitação não permite a Hart distinguir entre um sistema jurídico mínimo baseado exclusivamente em termos de poder e um sistema baseado em termos de autoridade. Deste modo, a solução para resolver o problema da normatividade é, novamente, incluir o povo no grupo reconhecedor relevante, afirmando-se que, conceitualmente, também o povo aceita a regra de reconhecimento.

Esta conclusão leva à terceira questão abordada no Capítulo 3. Hart já havia, em obra anterior a 'O Conceito de Direito' adotado a posição de que a população em geral participa da atividade de identificação das "normas fundamentais” do seu sistema jurídico, mas abandonou a tese após ser criticado por Hughes com um argumento que apela para a ignorância da maior parte da população quanto aos complexos detalhes de um sistema jurídico constitucional nas sociedades modernas. Este “argumento da ignorância” parte da observação de que na maioria dos sistemas contemporâneos os cidadãos comuns possuem uma relação mediata com o direito: eles não lêem leis e decretos, mas adquirem conhecimento jurídico “de um modo acidental”, ou, pior ainda, sequer possuem ideia do "esquema de autoridade” vigente, posto ainda que identificar normas fundamentais seria uma questão controvertida mesmo para os próprios juristas, 
estando completamente fora do alcance da massa dos cidadãos. Apresentou-se, também, uma segunda objeção levantada por Hart contra a possibilidade conceitual de inclusão do povo no grupo reconhecedor relevante, que diz respeito ao caráter eminentemente passivo da relação dos cidadãos leigos com o direito. O povo não seria apenas ignorante, mas um rebanho de ovelhas.

Procurou-se refutar ambos os argumentos e mostrar como o povo - ou parte expressiva dele - em geral participa da atividade de reconhecimento do direito, e que esta atividade não exige uma interação direta e diária com as complexidades do pensamento constitucional, mas uma atitude alerta de salvaguarda dos elementos fundamentais de seu sistema jurídico. Foi preciso relembrar que os conceitos de aceitação e de ponto de vista interno não possuem um requisito de expertise jurídica mínima, e podem muito bem ser pensados não em termos de "tudo ou nada”, mas em níveis, dependendo do grau e da forma de interação de cada subgrupo dentro da comunidade reconhecedora com o material jurídico. Ademais, o argumento de que é só o conjunto de atitudes e opiniões dos officials qua officials que importa, e que, portanto, somente é necessário e suficiente que eles aceitem a regra de reconhecimento última só se verificaria até certo ponto - o ponto em que tais opiniões e práticas passem a interferir nas bases do sistema político-jurídico aceitas pelo povo, nos pressupostos de validade do ordenamento, de tal modo que não se fale mais em uma regra de reconhecimento e um ordenamento, mas de um caso patológico de sistema jurídico. Procurou-se, portanto, explicar como uma correta compreensão do grupo relevante envolve o povo, de cuja adesão (ainda que manifestada de forma não ativamente participativa) depende a continuidade do sistema jurídico, e que o conteúdo da regra de reconhecimento última aponta para as fundações do ordenamento jurídico em questão, para os pressupostos básicos extraconstitucionais e extrajurídicos que fundamentam e singularizam os ordenamentos jurídicos estatais. Foi, portanto, proposta uma visão que seja aceitável não somente sob o foco da teoria analítica do direito, mas que tenha um potencial explicativo para uma visão do direito como ele é praticado e que seja compatível com a própria compreensão dos agentes relevantes, atendendo, assim, ao constraint hermenêutico.

Por fim, no Capítulo 4, as hipóteses iniciais B e C foram comprovadas com o desenrolar de uma tarefa de identificação dos aspectos mais importantes da regra de reconhecimento do direito brasileiro, em um trabalho de mapeamento que 
espera-se útil como ponto de partida para futuros estudos. O exercício de “sociologia jurídica descritiva” não se propôs a oferecer um detalhamento das práticas e interações entre os subgrupos relevantes (entre os quais o Poder Judiciário encabeçado pelo Supremo Tribunal Federal, o Congresso Nacional, a Presidência da República, os partidos políticos, a Academia jurídica e os cidadãos engajados); muito menos foi objeto deste trabalho um resumo das principais posições nos diversos temas de teoria constitucional. O foco sempre foi a identificação dos fatores relevantes que compõem a prática fundamental de identificação do direito válido no país.

O Brasil possui um sistema jurídico complexo, com vários detalhes interessantes tanto para teóricos do direito quanto para teóricos da constituição. A prometida formulação, que havia sido iniciada no início daquele capítulo, pode agora ser retomada, como último elemento que compõe a presente dissertação:

Regra de reconhecimento do Direito Brasileiro:

1. É válido como direito o próprio texto da Constituição da República Federativa do Brasil, de 5 de outubro de 1988, com todas suas emendas e o Ato das Disposições Constitucionais Transitórias (excluído, portanto, o preâmbulo), bem como todo o direito infraconstitucional com ele materialmente compatível;

2. Critério supremo do direito brasileiro: Os elementos limitantes materiais contidos nas cláusulas pétreas expressas no artigo $60, \S 4^{\circ}$ da Constituição Federal e o regime republicano e presidencialista (tal qual decidido pelo povo em plebiscito previsto pelo artigo $2^{0}$ do ADCT) constituem os elementos nucleares fundamentais do ordenamento jurídico brasileiro e são, portanto, irrevogáveis e inalteráveis. As limitações ao poder de emenda contidas no artigo 60 da Constituição da República Federativa do Brasil, de 5 de outubro de 1988 são inalteráveis por qualquer modo, formal ou informal. A soberania popular é pressuposto do regime constitucional democrático e, como tal inderrogável, sendo inalterável a titularidade do poder constituinte originário, que reside no povo. É também inalterável a titularidade e delegação conferida ao poder reformador, que não pode renunciar à sua competência, delegá-la ou alterar seus termos; 
3. As regras de adjudicação do direito brasileiro se encontram nas disposições referentes ao Poder Judiciário, contidas no Capítulo III, nos artigos 92 a 126 da Constituição Federal;

4. Em regra, prevalecem as decisões do Poder Judiciário a respeito da interpretação e aplicação das leis e da Constituição. Agentes públicos e cidadãos têm o dever de tratar como legalmente válidas as normas mantidas pelo Supremo Tribunal Federal conforme uma interpretação da Constituição que satisfaça o "constraint de plausibilidade", e o dever de tratar como legalmente inválidas as normas assim consideradas pelo Supremo Tribunal Federal conforme uma interpretação da Constituição que satisfaça o “constraint de plausibilidade”;

5. “Constraint de plausibilidade”: Decisões devidamente fundamentadas da maioria dos Ministros do Supremo Tribunal Federal devem contar como sendo a interpretação da Constituição e do ordenamento infraconstitucional a ser seguida, desde que os Ministros estejam de boa-fé procurando identificar o sentido do texto constitucional de acordo com uma metodologia coerente e que a decisão possa ser racionalmente ser baseada no texto constitucional;

6. A supremacia judicial é também limitada (i) nos casos em que estejam em jogo atos políticos, como o veto político do Chefe do Executivo; (ii) pelas emendas corretivas de jurisprudência;

7. A Constituição é norma jurídica superior do ordenamento e possui força normativa. Não há hierarquia entre normas constitucionais. A legislação infraconstitucional se divide em normas primárias e secundárias, sendo que estas retiram seu fundamento de validade daquelas, que por sua vez retiram seu fundamento de validade da Constituição;

8. Deve-se procurar conferir máxima efetividade às normas constitucionais. Não há uma lista exclusiva de métodos ou técnicas hermenêuticas aceitáveis no direito brasileiro, mas os intérpretes devem procurar basear suas interpretações em metodologias racionalmente coerentes e reconduzí-las ao texto constitucional;

9. A regra de alteração do direito brasileiro possui dois núcleos: o primeiro, formal, dispõe sobre os modos de alteração do direito vigente por meio de introdução de dispositivos normativos e diz respeito à atividade legiferante no Poder Legislativo nas esferas federal/nacional (artigos 59 a 69 da 
Constituição Federal, de acordo com as competências do artigo 22), estadual (artigo 25, da Constituição Federal), municipal (artigos 29 e 30 da Constituição Federal) e distrital (artigo 32 da Constituição Federal), além da competência concorrente do artigo 24. Também se incluem neste primeiro núcleo os atos normativos primários e secundários produzidos nos Poderes Executivo (artigo 84, IV e VI da Constituição Federal) e Judiciário (com destaque para as súmulas vinculantes (artigo 103-A da Constituição Federal) e as resoluções do CNJ (artigo 103-B da Constituição Federal);

10. A segunda forma de alteração do direito brasileiro diz respeito às mudanças informais, as alterações do significado dos dispositivos normativos independente de alteração do texto em si (com destaque para a mutação constitucional). A possibilidade de alteração informal, em especial de mutação constitucional é limitada (i) pelas possibilidades semânticas da norma, ou seja, pelos sentidos possíveis do texto que está sendo interpretado; e (ii) pela manutenção dos elementos fundamentais da Constituição (como indicado no critério supremo);

11. Admite-se a incorporação de valores morais como critério de validade jurídica por meio de sua densificação em princípios constitucionais explícitos ou implícitos. A colisão entre princípios deve ser preferencialmente resolvida mediante ponderação, seja com a aplicação dos princípios interpretativos (ou postulados) da proporcionalidade/ razoabilidade ou com a aplicação de standards, genéricos ou específicos. 


\section{6 Referências Bibliográficas}

ADLER, Matthew D. "Popular Constitutionalism and the rule of recognition: whose practices ground U.S. law?” In Northwestern University Law Review, Vol 100, n²2, 2006, pp 719-804. "Social Facts, Constitutional Interpretation, and the Rule of Recognition”. in ADLER, Matthew D., HIMMA, Kenneth Einar (ed) The Rule of Recognition and the U.S. Constitution. Oxford: Oxford University Press, 2009, pp. 193-233.

ALEXANDER, Larry; SCHAUER, Frederick. "On Extrajudicial Constitutional Interpretation”. In Harvard Law Review, v. 110, n.7, 1997, pp. 1359-1387. "Rules of Recognition, Constitutional Controversies, and the dizzying dependence of Law on acceptance” in ADLER, Matthew D., HIMMA, Kenneth Einar (ed) The Rule of Recognition and the U.S. Constitution. Oxford: Oxford University Press, 2009, pp. 175-192.

ARENA, Federico José. El convencionalismo jurídico: um recorrido analítico. Madri: Marcial Pons, 2014.

ATIENZA, Manuel; MANERO, Juan Ruiz. A Theory of Legal Sentences. Boston, Londres: Kluwer Academic Publishers, 1998.

BARBER, Nick. The Constitutional State. Oxford: Oxford University Press, 2010.

BARROSO, Luís Roberto. Curso de direito constitucional contemporâneo: os conceitos fundamentais e a construção do novo modelo. $1^{\text {a }}$ ed. São Paulo: Saraiva, 2009

BEEHLER, Rodger. "The Concept of Law and the Obligation to Obey". In American Journal of Jurisprudence, v. 23, n. 1, 1978, pp.120-142 
BIX, Brian. "Legal Positivism and "Explaining" Normativity and Authority”. In APA Newsletter on Philosophy and Law. Vol. 5, n.2, 2006, pp. 5-9

BULYGIN, Eugenio. “Algunas consideraciones sobre los sistemas jurídicos” in Doxa. Cuadernos de Filosofía del Derecho, n.9, 1991a, pp. 257279 . "Regla de reconocimiento: ¿Normas de obligación o critero conceptual? Réplica a Juan Ruiz Manero” in Doxa. Cuadernos de Filosofía del Derecho, n.9, 1991b, pp. 311-318

BURAZIN, Luka. "The rule of recognition and the emergence of a legal system”. Genoa-Slavic Seminar on Legal Theory. Dezembro/2014. Disponível em http://www.pravo.unizg.hr/_download/repository/The_rule_of_recognition_and_t he_emergence_of_a_legal_system.pdf. Acesso em 2 de janeiro de 2014.

COLEMAN, Jules. "Rules and Social Facts", in Harvard Journal of Law \& Public Policy Vol 14 , 1991, pp.703-725. . “The Conventionality Thesis”. Noûs, v. 35, 2001. Pp. 354387. . Markets, Morals and the Law. New York, Oxford University Press, 2003

COLEMAN, Jules L.; LEITER, Brian. “Legal Positivism”. In. Dennis Patterson, A Companion to Philosophy of Law and Legal Theory. Oxford: Blackwell Publishing, 1996.

DICKSON, Julie. "Is the rule of recognition really a conventional rule?" In Oxford Journal of Legal Studies, Vol. 27, 2007, pp. 1-30.

DIMOULIS, Dimitri e LUNARDI, Soraya. Curso de Processo Constitucional, $2^{\mathrm{a}}$ ed. São Paulo: Atlas, 2013.

DORF, Michael. "How the Written Constitution Crowds Out the Extraconstitutional Rule of Recognition”. in ADLER, Matthew D., HIMMA, Kenneth Einar (ed) The Rule of Recognition and the U.S. Constitution. Oxford: Oxford University Press, 2009, pp. 69-93

DWORKIN, Ronald. Levando os Direitos a Sério. São Paulo: Martins Fontes, 2002

FERREIRA FILHO, Manoel Gonçalves. O poder constituinte, $6^{\mathrm{a}}$ ed., São Paulo, Saraiva, 2014. 
“Significação e alcance das cláusulas pétreas”. In Revista de

Direito Administrativo. V. 202, out/dez 1995, p. 11-17.

GALLIGAN, D. J. Law in Modern Society. Oxford: Oxford University Press, 2007.

GALLIGAN, D.J. e VERSTEEG, Mila. “Theoretical Perspectives on the Social and Political Foundations of Constitutions" in GALLIGAN, D.J. e Versteeg, Mila (eds.) Social and Political Foundations of Constitutions. New York: Cambridge University Press, 2013, pp. 3-48

GARDNER, John. Law as a leap of faith. Oxford: Oxford University Press, 2012. . “Justification under Authority” in Canadian Journal of

Law and Jurisprudence v. .23, 2010, pp.71-110. . “Can There Be a Written Constitution?” in Oxford Studies in Philosophy of Law, V.1, 2011, pp.162-204. "Why law might emerge: Hart's problematic fable" in D’ALMEIDA, Luis Duarte, EDWARDS, James Edwards e DOLCETTI, Andrea (eds), Reading HLA Hart's The Concept of Law. Oxford: Hart Publishing 2013, pp 81-96

GREEN, Leslie. “The Concept of Law Revisited”, in Michigan Law Review, vol. 94, n.6, 1996, pp. 1687-1717 . "Positivism and Conventionalism”. In Canadian Journal of Law and Jurisprudence, v.12, n.1, 1999, pp.35-52 . "Law and Obligations" in COLEMAN, Jules; HIMMA, Kenneth Eimar e SHAPIRO, Scot (eds.) The Oxford Handbook of Jurisprudence and Philosophy of Law. Oxford: Oxford University Press, 2004, pp. 514-547

GREENWALT, Kent. "The Rule of Recognition and the U.S. Constitution” in ADLER, Matthew D., HIMMA, Kenneth Einar (ed) The Rule of Recognition and the U.S. Constitution. Oxford: Oxford University Press, 2009, pp. 1-46.

HACKER, P.M.S. “Hart's Philosophy of Law” in HACKER, P.M.S E RAZ, Joseph (eds) Law, Morality and Society: essas in honour of H.L.A Hart. Oxford: Oxford University Press, 1977 
HARDIN, Russell. "Why a Constitution?" in GALLIGAN, D.J. e VERSTEEG, Mila (eds.) Social and Political Foundations of Constitutions. New York: Cambridge University Press, 2013, pp. 51-72

HART, Herbert L. A. O Conceito de Direito. São Paulo: Martins Fontes, 2009.

Ensaios sobre Teoria do Direito e Filosofia. Rio de Janeiro: Elsevier, 2010.

Essays on Bentham. Jurisprudence and Political

Theory. Oxford: Clarendon Press, 1982

“Legal and Moral Obligation” in MELDEN, A.I. (ed).

Essays in Moral Philosophy. Seattle: University of Washington Press, 1958, pp. 82-107.

HESSE, Konrad. Temas Fundamentais do Direito Constitucional. São Paulo: Saraiva, 2009

HIMMA, Kenneth Eimar. "Law's Claim of Legitimate Authority" in COLEMAN, Jules. Hart's Postcript: Essays on the Postcript to The Concept of Law. Oxford: Oxford University Press, 2001, pp.271-310 . "Making Sense of Constitutional Disagreement: Legal Positivism, the Bill of Rights, and the Conventional Rule of Recognition in the United States” in Journal of Law in Society, Vol. 4, No. 2, 2003, pp. 149-218 . "Understanding the Relationship between the U.S. Constitution and the Conventional Rule of Recognition”. ” in ADLER, Matthew D., HIMMA, Kenneth Einar (ed) The Rule of Recognition and the U.S. Constitution. Oxford: Oxford University Press, 2009, pp. 95-121 . “Inclusive Legal Positivism”. In COLEMAN, Jules; HIMMA, Kenneth Eimar e SHAPIRO, Scott (eds) The Oxford Handbook of Jurisprudence and Philosophy of Law, 2012, DOI: 10.1093/oxfordhb/9780199270972.013.0004

HODSON, John. "Hart on the Internal Aspect of Rules." In ARSP: Archiv für Rechts- und Sozialphilosophie, v. 62, n. 3, 1976, pp. 381-399

HUGHES, Graham. “The existence of a Legal System.” In N.Y.U. Law Review, v. 35, 1960, pp. 1001-1030

KRAMER, Matthew. In defense of Legal Positivism: law without trimmings. Oxford: Oxford University Press, 1999 
Where Law and Morality Meet, Oxford: Oxford

University Press, 2004

KUTZ, Christopher. “The Judicial Community”, Philosophical Issues n. 11, pp. 442-469, 2001

LAGERSPETZ, Erik. The Opposite Mirrors: A Conventionalist Theory of Institutions. London: Kluwer Academic Publishers, 1995 “John Searle’s Social Ontology” in Analyse \& Kritik, n.21, 1999, pp.231-236

LAMOND, Grant. "Legal Sources, the Rule of Recognition, and Customary Law” in The American Journal of Jurisprudence, 2014, pp. 1-24 doi:10.1093/ajj/auu005 . "The Rule of Recognition and the Foundations of a Legal System”. In D'ALMEIDA, Luis Duarte, EDWARDS, James Edwards e DOLCETTI, Andrea (eds), Reading HLA Hart's The Concept of Law. Oxford: Hart Publishing 2013, pp. 97-122.

LEE, K.K. “Hart’s Primary and Secondary Rules”. In Mind, Vol. 77, n. 308, out.1968, pp. 561-564

LEITE, Fábio Carvalho. "Revisão da doutrina dos limites ao poder de reforma na constituição de 1988 (reflexões a partir do estudo de dois casos)”. Direito, Estado e Sociedade, v.9, n. 29, 2006, pp. 87-151. http://dx.doi.org/10.17808/des.v0i29.290.

MACCORMICK, Neil. Institutions of Law; an Essay in Legal Theory. Oxford: Oxford University Press, 2007

H. L. A. Hart. 2a ed. Redwood City: Stanford University Press, 2008.

MANERO, Juan. Ruiz. Jurisdicción y Normas: dos estudios sobre función jurisdicional y teoría del derecho. Madri: Centro de Estudios Constitucionales, 1990.

MARMOR, Andrei. Positive Law and objective values. Oxford: Oxford University Press, 2001a.

“Legal Conventionalism”. In COLEMAN, Jules (ed). Harts Postcript: Essays on the Postscript to The Concept of Law. Oxford: Oxford University Press, 2001b 
Social conventions: from language to law. Princeton:

Princeton University Press, 2009

. Philosophy of law. Princeton: Princeton University Press,

2011

MCBRIDE, William. “The Acceptance of a Legal System”. The Monist, v. 49, n. 3, 1965, pp. 377-396

MCDOUGAL, Myres; LASSWELL, Harold. "The Identification and Appraisal of Diverse Systems of Public Order”. American Journal of International Law, v. 53, 1959, pp. 1-29

MENDES, Gilmar Ferreira; COELHO, Inocêncio Mártires; BRANCO, Paulo Gustavo Gonet. Curso de Direito Constitucional. $4^{\text {a }}$ edição. São Paulo: Saraiva, 2009

MOREIRA, Vital. "Constituição e democracia na experiência portuguesa” in MAUÉS, Antônio G. (org.). Constituição e Democracia. São Paulo: Max Limonad, 2001, p. 261-290.

MOREIRA NETO, Diogo de Figueiredo. Curso de Direito Administrativo. $15^{\mathrm{a}}$ edição. Rio de Janeiro: Renovar, 2009

NINO, Carlos Santiago. Introducción al análisis del derecho. $2^{\mathrm{a}}$ ed. Buenos Aires: Astrea, 2003

PÁRAMO ARGÜELlES, Juan Ramon. de. H.L.A. Hart y la teoría analitica del derecho. Madrid: Centro de Estudios Constitucionales, 1984 "Entrevista a H.L.A. Hart" in Doxa. Cuadernos de Filosofía del Derecho, n.5, 1988.

PAYNE, Michael. "Hart's concept of a legal system.” In William. \& Mary Law Review, v. 18, 1976, pp. 287-319

PERRY, Stephen. "Hart on Social Rules and the Foundations of Law: Liberating the Internal Point of View.” In Fordham Law Review, v. 75, 2006. pp. 1171-1209.

POSTEMA, Gerald. "Coordination and Convention at the Foundations of Law” in The Journal of Legal Studies. V. 11, n. 1, 1982, pp. 165-220.

RAZ, Joseph. The Authority of Law: Essays on Law and Morality. Oxford: Clarendon Press, 1979. The Concept of a Legal System: an introduction to the Theory of the Legal System. 2a ed. Oxford: Clarendon Press, 1980. 
Ethics in the public domain. Oxford: Oxford University

Press, 1995

Practical Reason and Norms. $2^{\mathrm{a}}$ edição. Oxford: Oxford

University Press, 1999.

SAMPAIO, Nelson de Souza. O Poder de Reforma Constitucional. Bahia: Livraria Progresso Editora, 1954

SCHAUER, Frederick. Playing by the rules: A Philosophical Examination of Rule-Based Decision-Making in Law and in Life. Oxford, Oxford University Press, 1991

. “Constitutional Positivism,” in Connecticut Law Review v,

25, 1993, pp. 797-828.

. “Amending the Presuppositions of a Constitution". In

LEVINSON, Sanford (ed). In Responding to Imperfection: the theory and practice of constitutional amendment. New Jersey, Princeton University Press, 1995, pp.145-162.

. "Positivism Through Thick and Thin”. In: BIX, Brian (ed.),

Analyzing Law: New Essays in Legal Theory. Oxford: Oxford University Press, 1998, p. 65-78

SGARBI, Adrian. Teoria do Direito (Primeiras Lições). Rio de Janeiro: Lumen Juris, 2007;

SHAPIRO, Scott J. Legality. Cambridge: Harvard University Press, 2011. “On Hart's way out”. In COLEMAN, Jules (ed) Hart's

Postcript: Essays on the Postcript to the Concept of Law. New York, Oxford University Press, 2001, pp.149-192. . “Laws, Plans and Practical Reason”. In Legal Theory, n. 8, 2002, pp. 387-441 "What Is the Internal Point of View?" in Fordham Law Review. v.75, Issue 3, 2006, pp. 1157-1170.

"The 'Hart-Dworkin' debate: a short guide for the perplexed”. In University of Michigan Law School Public Law and Legal Theory Working Paper Series n. 77, 2007, pp.1-55.

"What is the rule of recognition (and does it exist)?" in ADLER, Matthew D., HIMMA, Kenneth Einar (ed) The Rule of Recognition and the U.S. Constitution. Oxford: Oxford University Press, 2009, pp. 235-268 
'Legal Practice and Massively Shared Agency', disponível em http://hvrd.me/ICOHVW Acesso 4 de janeiro de 2015;

SHECAIRA, Fábio Perin. "Dealing with Judicial Rhetoric: A Defence of Hartian Positivism”. Australian Journal of Legal Philosophy, v. 37, p. 131, 2012

SHINER, Roger. Norm And Nature. Oxford: Clarendon Press. 1992

SILVA, José Afonso da. Teoria do Conhecimento Constitucional. São Paulo: Malheiros, 2014.

SILVA, Virgílio Afonso da. "Ulisses, as sereias e o poder constituinte derivado: sobre a inconstitucionalidade da dupla revisão e da alteração no quorum de 3/5 para aprovação de emendas constitucionais". Revista de Direito Administrativo, v. 226, 2001, p. 11-32.

STRUCHINER, Noel. Para falar de regras - $\mathbf{O}$ positivismo conceitual como cenário para uma investigação filosófica acerca dos casos difíceis do

Direito. 2005. Tese de Doutorado disponível em: http://ged1.capes.gov.br/CapesProcessos/919300-ARQ/919300 5.PDF.

WACKS, Raymond. Understanding Jurisprudence. 1a ed, Oxford: Oxford University Press, 2005

WALDRON, Jeremy. “All We Like Sheep”. In Canadian Journal of Law and Jurisprudence, v.12, n.1, 1999, pp.169-186 . “Are constitutional norms legal norms?” in Fordham Law

Review, vol. 75, n.3, 2006, pp - 1697-1713 “Can there be a democratic jurisprudence?” in Emory Law Review, v.58, 2009a, pp.675-712. . "Who needs rules of recognition?” in ADLER, Matthew D., HIMMA, Kenneth Einar (ed) The Rule of Recognition and the U.S. Constitution. Oxford: Oxford University Press, 2009b.

WALUCHOW, Wilfrid. “Legal positivism, inclusive versus exclusive”. In E. Craig (Ed.), Routledge Encyclopedia of Philosophy. Londres: Routledge, 2001. 


\section{Legislação}

BRASIL. Decreto-Lei no 4.657, de 4 de setembro de 1942. Disponível em http://www.planalto.gov.br/ccivil_03/decreto-lei/Del4657compilado.htm. Acesso em 19 de dezembro de 2014.

BRASIL. Emenda Constitucional $n^{0}$ 26, de 27 de novembro de 1985. Disponível eletronicamente em http://www.planalto.gov.br/ccivil_03/constituicao/Emendas/Emc_anterior1988/e mc26-85.htm. Acesso em 10 de dezembro de 2014

BRASIL. Constituição da República Federativa do Brasil de 5 de outubro de $1988 . \quad$ Disponível eletronicamente em http://www.planalto.gov.br/ccivil_03/constituicao/Emendas/Emc_anterior1988/e mc26-85.htm. Acesso 20 de outubro de 2014.

BRASIL. Emenda Constitucional n ${ }^{\circ}$ 29/2000, de 13 de setembro de 2000. http://www.planalto.gov.br/ccivil_03/constituicao/Emendas/Emc/emc29.htm. Acesso em 13 de janeiro de 2015.

BRASIL. Proposta de Emenda Constitucional 33/2011. Disponível em http://www.camara.gov.br/proposicoesWeb/fichadetramitacao?idProposicao=503 667.

ESTADOS UNIDOS DA AMÉRICA. The Constitution of the United States of America. 1787. Disponível eletronicamente em http://www.law.cornell.edu/constitution/overview. Acesso 21 de setembro de 2014.

REINO DE ESPANHA. Lei 1/1977, de 4 de janeiro de 1977. Disponível eletronicamente em http://www.boe.es/boe/dias/1977/01/05/pdfs/A0017000171.pdf. Acesso em 6 de janeiro de 2015.

REPÚBLICA PORTUGUESA. Lei Constitucional $n^{\circ} 1 / 89$ de 8 de julho de 1989. Disponível em http://www.cne.pt/sites/default/files/dl/crp_1989.pdf. 


\section{Decisões Judiciais}

BRASIL. Supremo Tribunal Federal ADI 815/DF, Relator Ministro Moreira Alves, julgamento em 28-3-1996, Plenário, DJ 10-5-1996.

BRASIL. Supremo Tribunal Federal, ADI 981 MC/PR, Relator Ministro Néri da Silveira, julgamento em 17-12-1994, Plenário, DJ de 5-8-1994.

BRASIL. Supremo Tribunal Federal, ADI 2.076, Relator Ministro Carlos Velloso, julgamento em 15-8-2002, Plenário, DJ de 8-8-2003.

BRASIL. Supremo Tribunal Federal. ADPF 1-RJ. Relator Ministro Néri da Silveira, Julgamento 03-02-2000, Plenário, Publicação DJ 07-11-2003

BRASIL. Supremo Tribunal Federal, AI 386.820-AgR-ED-EDv-AgR-ED, Relator Mininstro Celso de Mello, julgamento em 24-6-2004, Plenário, DJ de 4-22005.

BRASIL, Supremo Tribunal Federal. STF - Súmula 668. 15 de agosto de 2007. Disponivel eletronicamente em: http://www.conteudojuridico.com.br/?artigos\&ver=237.2187\&seo=1. Acesso em: 10 de janeiro de 2015.

BRASIL. Supremo Tribunal Federal, ADC 12-DF. Relator Ministro Carlos Ayres Britto, Julgamento em 20-08-2008, Plenário, DJe 18-12-2009

BRASIL. Supremo Tribunal Federal. ADPF 132-RJ. Relator Ministro Carlos Ayres Britto. Julgamento em 05-05-2011, Plenário, DJe- 14-10-2011

\section{Sítios Virtuais}

http://www.iep.utm.edu/legalpos/. Acesso em 5 de junho de 2014

http://www.bbc.com/news/world-middle-east-26248275. Acesso em 28 de dezembro de 2014.

http://leiterlegalphilosophy.typepad.com/leiter/2008/02/dickson-on-

the.html. Acesso em 29 de dezembro de 2014 